UNIVERSIDADE DE SÃO PAULO

FACULDADE DE ECONOMIA, ADMINISTRAÇÃO E CONTABILIDADE DEPARTAMENTO DE ECONOMIA

PROGRAMA DE PÓS-GRADUAÇÃO EM ECONOMIA

ESSAYS IN EMPIRICAL POLITICAL ECONOMICS

Luís Eduardo Negrão Meloni

Prof. Dr. Ricardo de Abreu Madeira

SÃO PAULO

2015 
Prof. Dr. Marco Antonio Zago

Reitor da Universidade de São Paulo

Prof. Dr. Adalberto Américo Fischmann

Diretor da Faculdade de Economia, Administração e Contabilidade

Prof. Dr. Helio Nogueira da Cruz

Chefe do Departamento de Economia

Prof. Dr. Márcio Issao Nakane

Coordenador do Programa de Pós-Graduação em Economia 


\section{LUÍS EDUARDO NEGRÃO MELONI}

\section{ESSAYS IN EMPIRICAL POLITICAL ECONOMICS}

Tese apresentada ao Departamento de Economia da Faculdade de Economia, Administração e Contabilidade da Universidade de São Paulo como requisito para a obtenção do título de Doutor em Ciências.

Orientador: Prof. Dr. Ricardo de Abreu Madeira 
FICHA CATALOGRÁFICA

Elaborada pela Seção de Processamento Técnico do SBD/FEA/USP

Meloni, Luís Eduardo Negrão

Essays in empirical political economics / Luís Eduardo Negrão Meloni. - São Paulo, 2015.

$114 \mathrm{p}$.

Tese (Doutorado) - Universidade de São Paulo, 2015.

Orientador: Ricardo de Abreu Madeira.

1. Economia política 2. Instituições 3. Captura política 4. Desigualdade de renda 5. Ditadura militar 6. Filiação partidária I. Universidade de São Paulo. Faculdade de Economia, Administração e Contabilidade. II. Título.

CDD - 330 
To my family. 


\section{ACKNOWLEDGEMENTS}

Firstly, I thank Ricardo Madeira, my advisor, and Marcos Rangel, who I always considered my co-advisor even though that was never formally his position. I owe both of them much more than what is reflected in this thesis.

A very special thanks goes out to Eliana La Ferrara for giving me the greatest opportunity of my life, for believing in my work and for teaching me so much during this last year. Without her this thesis would simply not be possible.

I also thank Claudio Ferraz, Frederico Finan and Alberto Chong for all the contributions they gave to this thesis, particularly to the second chapter. Claudio deserves a special thank for the valid contributions in the other chapters as well as for the great talks and great advices he gave me in the few times we met in Europe during the last year.

I must also acknowledge my Professors at Univeristy of São Paulo and at Bocconi University, specially Fernando Botelho, Marcos Nakaguma, Mauro Rodrigues, Fernanda Estevan, Selim Gulesci and Diego Ubfal for everything they taught me and for all the opportunities they gave me. Rodrigo Soares and João Manoel also should be acknowledged by the comments and suggestions gave during the presentation of this thesis.

I am also thankful to everyone from the European development network that somehow contributed to the work reflected in this thesis by making comments and suggestions during conferences, seminars and summer schools. A very special thanks goes out to my friends Andrea Guariso and Caterina Alacevich.

I also thank my colleagues and friends at the University of São Paulo, specially Ana Barufi, Antonio Morales, Danilo Ramalho, Maximiliano Barbosa and Thomaz Gemigniani, and at Bocconi University, specially Santiago Perez, Francesco Giovanardi and my great friend Alexsandros Cavgias, whose contributions to this work are enormous. Isabela Morbach also deserves a special thank you for all the support and for the advices with all the law-related issues of this thesis. Lucas Câmara should also be remembered for the encouragement given in crucial moments.

Funding support from CAPES, CNPq and from the PODER-CEPR Network is also gratefully acknowledged.

Last but not the least, I would like to thank my family for supporting me throughout writing this thesis and my life in general. 


\section{RESUMO}

Esta tese é composta por três ensaios empíricos em economia política.

O primeiro capítulo investiga se a presença de prefeitos nomeados em um subconjunto de municípios durante a ditadura brasileira levou à captura por parte da elite. Isso é feito comparando medidas de desigualdade após a redemocratização entre municípios que tiveram prefeitos nomeados e municípios onde os prefeitos foram eleitos democraticamente. Os principais resultados deste capítulo são consistentes com a hipótese de captura e indicam que a desigualdade de renda aumentou mais em municípios que tiveram prefeitos nomeados pelo regime e que isso se deve principalmente a um aumento na parcela de rendimentos auferidos pelos mais ricos.

O segundo capítulo investiga em que medida os veículos de comunicação são propensos a captura política no contexto da ditadura brasileira. Isso é feito investigando os efeitos da Rede Globo, a principal emissora de televisão brasileira, sobre os resultados eleitorais das eleições para prefeito durante a ditadura brasileira, especialmente sobre o percentual de votos obtido pela ARENA, o partido de situação durante a ditadura militar. Os principais efeitos mostram que durante os primeiros anos da ditadura, a Globo tem um efeito positivo sobre o percentual de votos obtidos pela ARENA. Nos últimos anos, no entanto, o efeito torna-se negativo e, em média, sobrepõe-se o resultado positivo dos primeiros anos. São fornecidas evidências de que esta quebra no efeito da Globo está associado a uma mudança na posição da empresa em relação ao regime e no conteúdo dos programas transmitidos por ela.

O terceiro capítulo investiga se professores com fortes posições partidárias são capazes de interferir nos resultados eleitorais a partir de influência exercida sobre o voto dos seus alunos. Para isso são utilizados dados sobre filiação partidária de eleitores, sobre professores das escolas públicas e sobre resultados eleitorais e características dos eleitores no Estado de São Paulo, Brasil. As principais conclusões deste capítulo sugerem um efeito positivo e significativo da presença de professores filiados sobre o desempenho eleitoral do partido correspondente, especialmente em eleições majoritárias. 


\begin{abstract}
This thesis is a collection of three independent essays in empirical political economics.

The first chapter investigates if the presence of appointed mayors in a subset of municipalities during the Brazilian dictatorship led to elite capture. This is done comparing measures of inequality after redemocratization between municipalities that had appointed mayors with municipalities where mayors were elected directly. The main results are consistent with the hypothesis of elite capture and indicate income inequality increased more in municipalities that had mayors appointed by the regime.

The second chapter investigates the extent to which media vehicles are prone to political capture in the context of the Brazilian dictatorship. This is done by investigating the effects of Rede Globo, the main Brazilian television station, on electoral outcomes of mayoral elections during the Brazilian dictatorship, mainly on the share of votes obtained by ARENA, the ruling party during the dictatorship. The main effects documented in this chapter show that during the first years of the military dictatorship, Globo has a positive effect on ARENA's vote-share. In the latter years, however, the effect becomes negative and, on average, overlaps the positive result. It is provided evidence that this break in the effect of Globo is associated with a change in the company's position towards the regime and in the content of the shows broadcast by Globo.

The third chapter investigates if teachers with strong partisan stances are capable of influencing electoral outcomes through shaping their students' voting behavior. This is done by exploiting unique datasets on party-affiliated voters, on public high school teachers and on election results and voter characteristics in the state of São Paulo, Brazil. The main findings of this chapter are suggestive of a positive and significant effect of the presence of affiliated teachers on the electoral performance of the corresponding party, especially in elections based on plurality voting systems.
\end{abstract}




\section{SUMMARY}

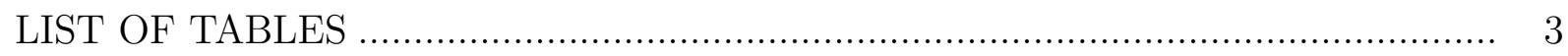

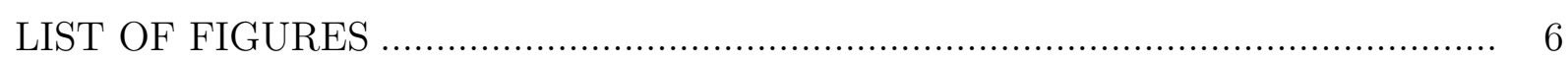

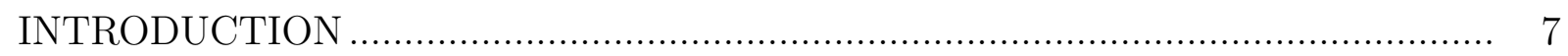

1 NON-DEMOCRATIC REGIMES AND ELITE CAPTURE: EVIDENCE FROM THE BRAZILIAN MILITARY DICTATORSHIP ..................................... 9

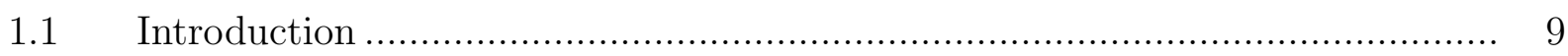

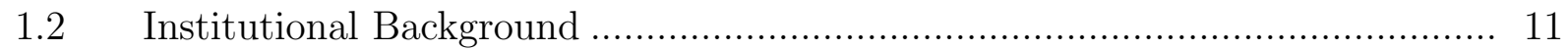

1.2.1 Brazilian dictatorship and municipal elections ..................................... 11

1.2.2 Economic growth and the rise in income inequality .............................. 13

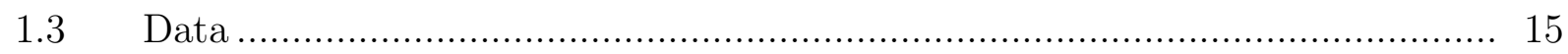

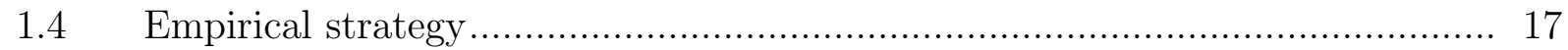

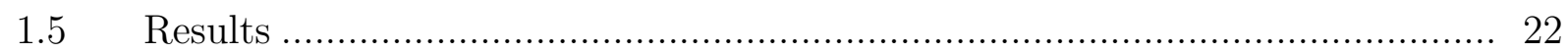

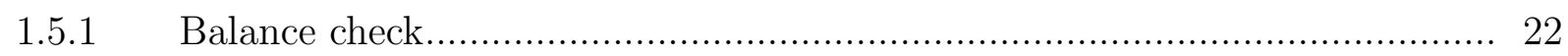

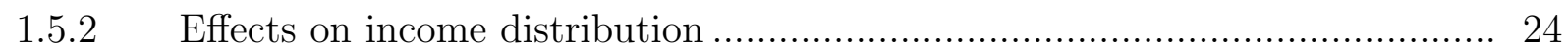

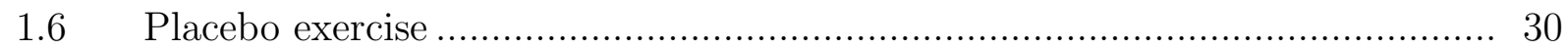

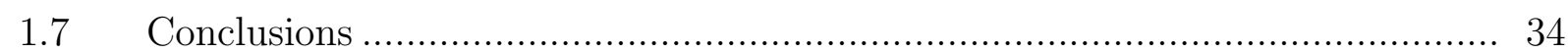

2 MEDIA CAPTURE IN NON-DEMOCRATIC REGIMES: EVIDENCE FROM THE BRAZILIAN DICTATORSHIP …....................................... 35

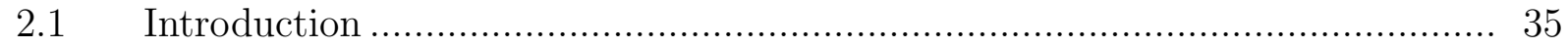

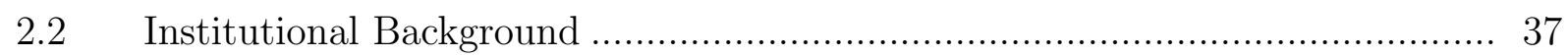

2.2.1 Elections during the Brazilian dictatorship ..................................... 37

2.2.2 Rede Globo and the military regime .................................................. 40

2.2.3 The importance of Globo Novelas ........................................................... 41

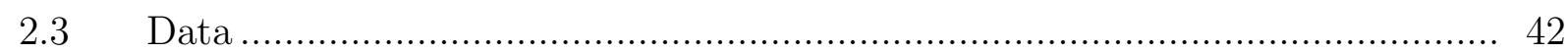

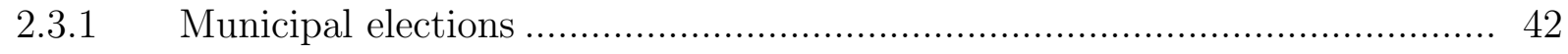

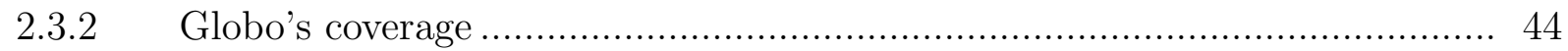

2.3.3 Novela content analysis................................................................. 46

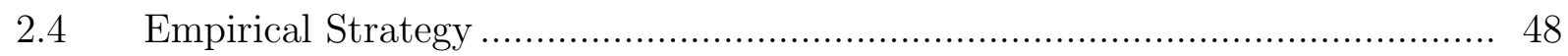

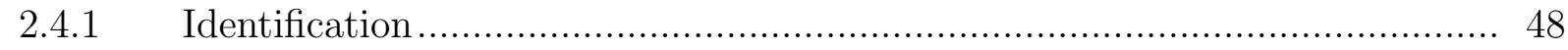

2.4.2 Effect on electoral outcomes ....................................................... 50

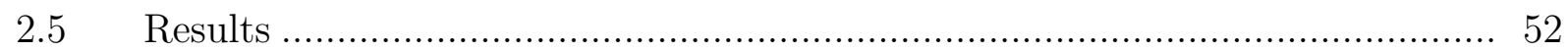

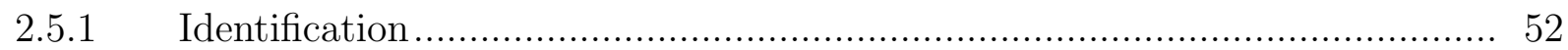




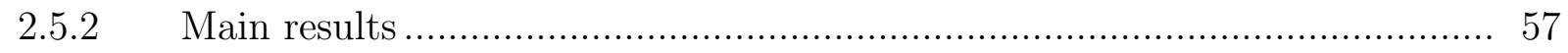

2.5.3 Heterogeneity by socioeconomic characteristics ................................... 61

2.5.4 Heterogeneity by television content (novelas) ...................................... 62

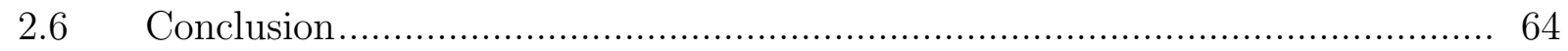

3 POLITICAL PREACHING IN THE CLASSROOM: EVIDENCE FROM TEACHERS' PARTY AFFILIATION IN BRAZILIAN PUBLIC SCHOOLS .......... 67

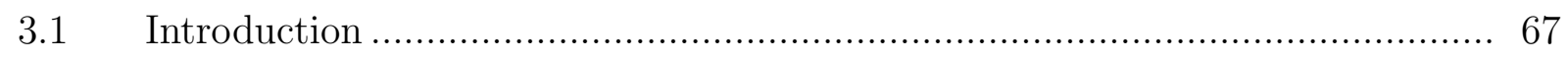

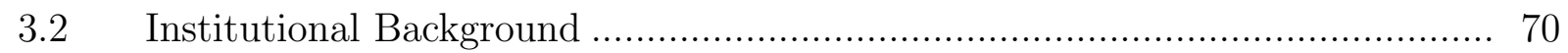

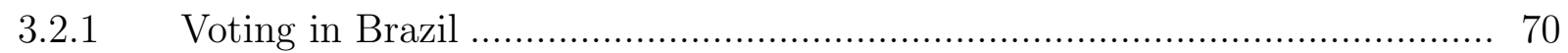

3.2.2 The Brazilian Public Educational System ............................................. 71

3.2.3 Student and Teacher Placement in São Paulo's Public Schools.................... 72

3.3 Data and Estimation Framework .............................................................. 73

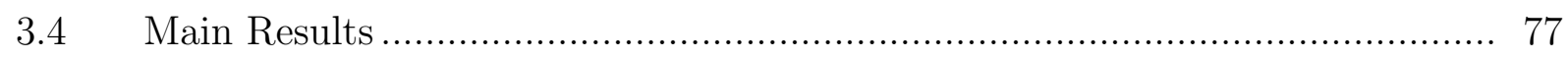

3.5 Further Exercises ............................................................................... 81

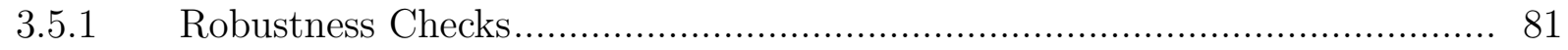

3.5.2 Effects on Turnout ............................................................................. 84

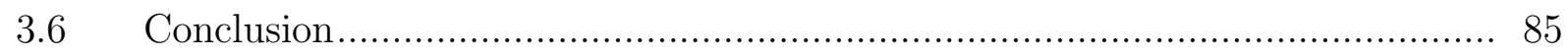

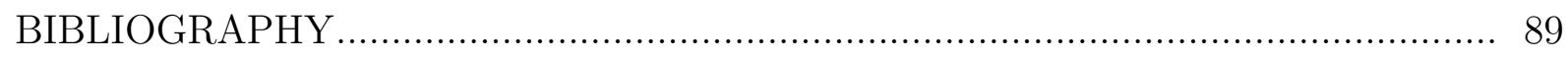

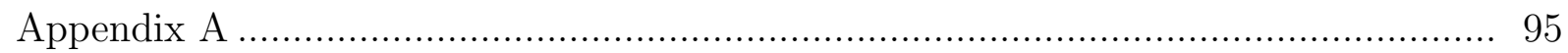

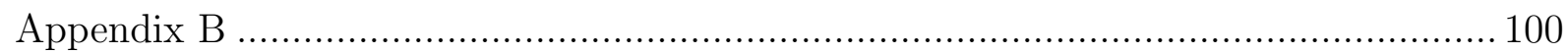

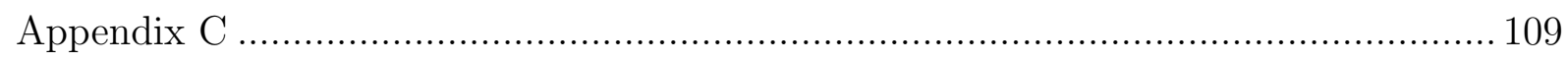




\section{LIST OF TABLES}

Table $1 \quad$ Municipalities with appointed mayors 16

Table 2 Mean of the baseline (1970) socioeconomic characteristics.

Table 3 Balance check of the baseline characteristics between municipalities with appointed mayors and the control group

Table 4 Balance check of the baseline characteristics between municipalities with appointed mayors and the control group (using N-1 covariates to match)

Table $5 \quad$ Effect on the Theil index 26

Table $6 \quad$ Effect on income distribution in 1991 29

Table $7 \quad$ Placebo: balance check of the baseline characteristics between treated municipalities and the control group

Table 8 Placebo: effect on the Theil index 32

Table 9 Placebo: effect on income distribution in 1991 33

Table 10 Direct elections during the Brazilian military dictatorship 39

Table 11 Novela content coding. 47

Table 12 Novela content analysis: Share of novelas aired. 48

Table 13 Possible selection in Globo coverage (ARENA vote-share) 54

Table 14 Possible selection in Globo coverage (Turnout and Share of blank and null votes)

Table 15 Placebo regressions 58

Table 16 Effect of Globo on ARENA's vote-share 59

Table 17 Effect of Globo on turnout and share of blank and null votes. 60

Table 18 Heterogeneous effect (Share of households with televisions and average schooling)

Table 19 Heterogeneous effects by novela content 65

Table 20 Share of Teachers Affiliated to Each Party....... 75 
Table 21 Effect of Teachers Affiliated to the PT on the Vote Share at the 2010 Presidential Election

Table 22 Effect of Affiliated Teachers on Each Party's Vote Share in Different Elections

Table 23 Effect of Affiliated Teachers on Each Party's Vote Share in Different Elections - Placebo Group 83

Table 24 Effect of Affiliated Teachers on Voter Turnout...... 85

Table $25 \quad$ Balance check of the baseline characteristics between municipalities with appointed mayors and the control group (without matching) .. 95

Table 26 Effect on the Theil index (without matching) 96

Table $27 \quad$ Effect on income distribution in 1991 (without matching) ................... 97

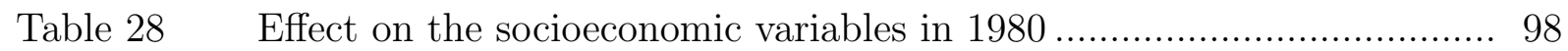

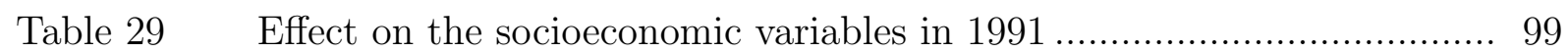

Table $30 \quad$ Possible selection in Globo's coverage …............................................ 100

Table 31 Possible selection in Globo's coverage ............................................... 101

Table $32 \quad$ Effect of Globo on ARENA's vote-share …....................................... 102

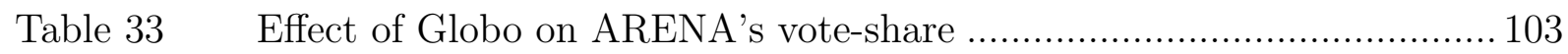

Table 34 Possible selection in Globo's coverage (Turnout)................................. 104

Table 35 Possible selection in Globo's coverage (share of blank and null votes) ... 105

Table 36 Effect of Globo on turnout vote-share Dependent variable: Turnout in $t, t=1972$, 1976,1982

Table 37 Effect of Globo on the share of blank and null votes Dependent variable: share of blank and null votes in $\mathrm{t}, \mathrm{t}=1972,1976,1982$

Table 38 Heterogeneous effects by novela content 108

Table 39 Distribution of TSE Districts across Municipalities 109

Table 40 Distribution of Municipalities across TSE Districts 109

Table 41 Summary Statistics by Estimating Sample $-1 / 3$ 110

Table 42 Summary Statistics by Estimating Sample $-2 / 3$. 111 


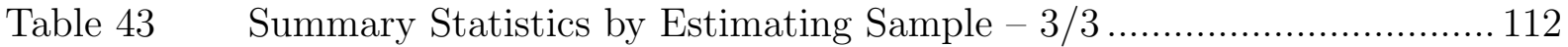




\section{LIST OF FIGURES}

Figure 1 Timeline of the relevant events during the Brazilian dictatorship ............ 14

Figure 2 Municipalities with appointed mayors .......................................... 19

Figure 3 Municipalities with appointed mayors in the sample and neighbors used as the control group ................................................................. 20

Figure 4 Theil index in municipalities with appointed and with elected mayors ..... 25

Figure 5 Placebo exercise: Treated municipalities and neighbors used as the control group ...................................................................................... 31

Figure 6 Electoral outcomes in 1972, 1976 and 1982 mayoral elections ................. 43

Figure $7 \quad$ Increase of Rede Globo coverage over time........................................... 45

Figure 8 Geographical distribution of Rede Globo's coverage over time................ 46

Figure 9 Effect of Globo on ARENA's vote-share vs share of novelas with political content

Figure 10 Administrative Hierarchy of Electoral Procedures in Brazil

Figure 11 Municipalities with appointed mayors in the sample and neighbors used as the control group (without matching)

Figure 12 Municipalities in the State of São Paulo. Highlighted: City of São Paulo. 113

Figure 13 Polling Districts in the City of São Paulo

Figure 14 A Public School Employed as a Polling Place.

Figure 15 A Public School Classroom Used as a Polling Station. 


\section{INTRODUCTION}

This thesis is a collection of three independent essays in empirical political economics. The first two chapters investigate the possibility of capture of institutions in non-democratic regimes, particularly in the context of the Brazilian dictatorship. The first chapter investigates the existence of elite capture during the Brazilian dictatorship. The second chapter analyses the possibility of media capture in the same context. The third chapter investigates the role played by high-school teachers in the electoral process by analysing their capability of influencing their students' voting behavior.

The first chapter is entitled "Non democratic regimes and elite capture: Evidence from the Brazilian dictatorship" and it investigates the existence of elite capture at local levels of government in the context of the Brazilian dictatorship, a particular interesting context because during the dictatorship the mayors of some municipalities were appointed by the regime, while others were elected directly. This is done comparing measures of inequality after redemocratization between municipalities that had appointed mayors with (a subset of) municipalities where mayors were elected directly. To overcome the issue of the selection of municipalities, a combination of geographic regression discontinuity (GRD) design with matching techniques is employed, relying on the hypothesis that the main source of selection is related to the geographic characteristics of the municipalities. The main results of this chapter indicate income inequality increased more in municipalities that had mayors appointed by the regime and that was mainly due to an increase in the share of income earned by the richest. Although lack of more detailed data does not allow this chapter to explore the channels through which this wealth concentration occurred, the results are consistent with the hypothesis of elite capture.

The second chapter is entitled "Media capture in non-democratic regimes: Evidence from the Brazilian dictatorship" and it investigates the extent to which media vehicles are prone to political capture in the context of the Brazilian dictatorship. This is done by investigating the effects of Rede Globo, the primary Brazilian television station, on electoral outcomes of mayoral elections during the dictatorship, mainly on the share of votes obtained by ARENA, the ruling party during this period. The main effects documented in this chapter show that during the first years of the military dictatorship, Globo has a positive effect on ARENA's vote-share. In the latter years, however, the effect becomes negative and, on average, overlaps the positive result. In order to better understand this 
sudden break in Globo's effect, the content of Brazilian soap operas, known as novelas, were coded and used in the analysis presented here. The main results show that exposure to novelas with politically related content has a negative effect on ARENA's vote-share. These results are consistent with the anecdotal evidence suggesting that in response to the new context of political and economic crisis, Globo assumed a critical role in the last years of the regime. They are also consistent with a theoretical result by Prat \& Strömberg (2011), according to which the presence of a news-related profit motive makes political capture of media vehicles more difficult to happen.

The third chapter is entitled "Political Preaching in the classroom: Evidence from Teacher's Party Affiliation" and it investigates the extent to which teachers with strong partisan stances are capable of influencing electoral outcomes through shaping their students' voting behavior. This question is addressed by exploiting unique datasets on party-affiliated voters and on public high school teachers in the state of São Paulo, Brazil - through which it is possible to identify teachers' political affiliations. Along with such information, very rich datasets on election results and voter characteristics are also used to explore the relationship between the density of affiliated teachers in a given region and electoral outcomes observed for that region. To overcome endogeneity issues such as that of selection in the assignment of teachers to schools and of voters to polling places, for instance, it is exploited the intensity of the hypothesized effect according to electorate characteristics at the polling station level, a very specific site within the polling district to which voters and teachers are suggested not to be able to select themselves. The main findings of this chapter are suggestive of a positive and significant effect of the presence of affiliated teachers on the electoral performance of the corresponding party, especially in elections based on plurality voting systems. However, the results also indicates that such an effect is more relevant for (and possibly restricted to) teachers affiliated to the Workers' Party. In addition, such teachers do not appear to have an effect on electoral turnout by their students. 


\section{NON-DEMOCRATIC REGIMES AND ELITE CAPTURE: EVIDENCE FROM THE BRAZILIAN MILITARY DICTATORSHIP}

\subsection{Introduction}

The question of how the capture of the political process by special interest groups and elites can influence policies and economic outcomes has been studied in recent years both by theoretical and by empirical political economy literature. ${ }^{1}$ It is surprising, however, that the empirical literature rarely addresses the question of capture at local levels of government, especially considering that theoretical models have identified a number of factors that may lead to greater capture at the local levels, such as the greater cohesiveness of local interest groups and higher levels of voter ignorance. ${ }^{2}$

This chapter addresses this question by investigating the presence of elite capture at the local level in the context of the Brazilian military dictatorship. This is a particular interesting context because during the dictatorship the mayors of some Brazilian municipalities were appointed by the regime, while others were elected directly. This research, therefore, is interested in investigating if the presence of appointed mayors in a subset of municipalities during the Brazilian dictatorship led to elite capture. In this regard, it compares measures of inequality between municipalities that had appointed mayors with a subset of municipalities where mayors were elected directly.

The Brazilian military dictatorship is an interesting case study not only because it provides this unusual variation in political institutions at the local level but also because Brazil faced high rates of economic growth along with a concentration of income in this period. In particular, this period was characterized by a large number of ambitious projects conducted by the central government, such as the construction of roads, powerplants, and heavy industry. Large amounts of resources were spent on these projects, which allows to investigate the presence of practices related to capture. ${ }^{3}$

\footnotetext{
${ }^{1}$ See Acemoglu \& Robinson (2008) for a detailed discussion of the extent to which political institution can affect economic outcomes.

${ }^{2}$ The possibility of capture at the local level is known as the "Madisonian presumption", according to which "the lower the level of government, the greater is the extent of capture by vested interests, and the less protected minorities and the poor tend to be" (Bardhan \& Mookherjee (2000)).

${ }^{3}$ See more about the projects conducted by the central government during the Brazilian dictatorship at <http://oglobo.globo.com/economia/ obras-da-ditadura-do-brasil-grande-ao-brasil-do-ganho-de-eficiencia-11959341> .
} 
The selection of disenfranchised municipalities ${ }^{4}$ is the main empirical challenge of this research since they were not randomly assigned, but rather chosen by the federal government for specific reasons and, therefore, should be expected to be different from municipalities where mayors were democratically elected. The empirical strategy employed combines a geographic regression discontinuity (GRD) design with matching techniques, thus resembling the strategy employed by Larreguy, Marshall \& Snyder (2014). The strategy relies on the hypothesis that the main source of selection (for some disenfranchised municipalities) is geographic characteristics. Therefore, the empirical strategy uses matching techniques to compare municipalities that had appointed mayors with their most similar neighbor (in terms of the Mahalanobis distance).

The main results of this chapter indicate income inequality increased more in municipalities that had mayors appointed by the regime. Moreover, the results suggest income inequality increased more in this group of municipalities as a result of an increase in the share of income earned by the richest. Although this research is not able to explore the channels through which this wealth concentration occurred due to lack of more detailed data, the evidence that economic growth privileged a few individuals at the top of the income distribution is consistent with the hypothesis of elite capture.

The empirical literature documenting evidence of elite capture at the local level is scarce. Araujo et al. (2008), studying social fund investment in Ecuador, find that poorer villages are more likely to receive projects that provide excludable goods to the poor, evidence that is consistent with the hypothesis of elite capture. Galasso \& Ravallion (2005) find that the results of Bangladesh's Food-for-Education program are worse in communities with higher land inequality. They argue this reflects the greater capture of the benefits by the elite when the poor are less powerful.

The present chapter contributes to at least three strands of the literature. First, it relates to the more general literature that investigates democratic capture by elites and other interest groups. While there has been substantial development in the theoretical literature (Acemoglu \& Robinson (2008)), empirical works have focused on providing evidence on existing practices that are consistent with the story of capture (Bo \& Tella (2003), Acemoglu, Robinson \& Santos (2013)) rather than documenting in which situations elite capture is more likely to happen. This chapter contributes to this stream of the litera-

\footnotetext{
${ }^{4}$ The expressions disenfranchised municipalities and municipalities with appointed mayors are used interchangeably in this chapter.
} 
ture by providing evidence consistent with elite capture in a particular situation and by enhancing the role of local officials as representatives of the central regime.

This research also relates to the literature that studies the legacies of non-democratic regimes and the outcomes of new democracies (Keefer (2007), Martinez-Bravo (2014), Martinez-Bravo \& Mukherjee (2015)). It contributes to this literature by showing that the legacies of the Brazilian dictatorship were accentuated in municipalities that had less democratic institutions.

Finally, this research relates to several papers that discuss the incentives of appointed and elected representatives (Besley \& Coate (2003), Alesina \& Tabellini (2007), MartinezBravo et al. (2011)) and discuss whether the allocation of central resources is politically driven (Brollo \& Nannicini (2012), Solé-Ollé \& Sorribas-Navarro (2008), Khemani (2007), Arulampalam et al. (2009), Leão (2011)).

The remaining of the chapter is organized as follows. Section 1.2 describes the political system in Brazil during the dictatorship period as well as the main features of the macroeconomic policy at that time. Section 1.3 describes the datasets used in this chapter. Section 1.4 details the empirical strategy employed. Sections 1.5 and 1.6 present the main empirical results. Section 1.7 concludes.

\subsection{Institutional Background}

\subsubsection{Brazilian dictatorship and municipal elections}

The military government began with the 1964 coup d'état led by the armed forces that deposed President João Goulart and put in charge Humberto Castelo Branco and it lasted for more than 20 years until José Sarney, elected by indirect elections, took office as president in 1985 .

The Brazilian military dictatorship had a unique political system compared with other dictatorships, when the head of government is in power uninterruptedly, parties are forbidden to work, Congress is closed, and elections are suspended. During the majority of the years of the military government, military presidents and state governors were chosen by 
the National Congress and state legislative houses, respectively. ${ }^{5}$ Senators, congressmen, state legislators, and city councilors, in turn, continued to be chosen by direct vote.

The choice of mayors was even more unusual. In the majority of municipalities, mayors were elected directly throughout the regime period. In three groups of municipalities, however, mayors were appointed by the state governors, namely in state capitals, in municipalities considered to be water resorts, ${ }^{6}$ and in municipalities located in national security areas (NSAs).

State capitals started having mayors appointed in February 1966, after AI-3, Institutional Act Number 3, which stated that state governors should be chosen by the legislative houses and the mayors of state capitals should be nominated by the governor and endorsed by the legislative houses.

Water resorts, on their turn, began to have mayors appointed after Constitutional Amendment Number 1, from October $1969^{7}$ which stated that mayors of municipalities considered to be water resorts would be nominated by the governor, as in the case of state capitals. Brazilian law states that to be considered to be a water resort a municipality has to meet two conditions. First, it needs to have water sources that can be explored. ${ }^{8}$ Second, it needs to be explicitly declared as a water resort by state law. ${ }^{9}$

Finally, mayors of municipalities in NSAs began to be appointed after law number 5449, from $1968,{ }^{10}$ which classified several municipalities under the condition of NSA and stated that the mayors of these municipalities should be nominated by the state governor and endorsed by the president. The criteria that led the government to classify municipalities in this way are unclear in the official documents; however, according to Nicolau (2012), these were basically border municipalities and municipalities in areas that had large stateowned enterprises. Section 1.4 presents a map with the distribution of disenfranchised municipalities and shows that the majority of municipalities located in NSAs are border

\footnotetext{
${ }^{5}$ See AI-2, Institutional Act Number 2, from October 1965, available at <http://www.planalto.gov. br/ccivil_03/AIT/ait-02-65.htm>; see also AI-3, Institutional Act Number 3, from February 1966, available at <http://www.planalto.gov.br/ccivil 03/AIT/ait-03-66.htm>.

${ }^{6}$ or considered to be Estâncias Hidrominerais, to use the Portuguese expression.

${ }^{7}$ Available at <http://www.planalto.gov.br/ccivil_03/constituicao/Emendas/Emc_anterior1988/ emc01-69.htm>.

${ }^{8}$ See law n. 7841/1945 available at <http://www.planalto.gov.br/ccivil_03/decreto-lei/1937-1946/ Del7841.htm>.

${ }^{9}$ See law n. 2661/1955 available at <http://www.planalto.gov.br/ccivil03/leis/1950-1969/L2661. htm $>$.

${ }^{10}$ Available at <http://www.planalto.gov.br/ccivil03/leis/1950-1969/L5449.htm>.
} 
municipalities.

Four rounds of mayoral elections happened during the dictatorship. The first round took place between 1965 and 1970, while the other three rounds happened in 1972, 1976, and 1982 in all states of the country simultaneously. In 1985, at the end of the dictatorship, elections for mayor happened in all Brazilian municipalities.

The partisan system in Brazil during the period analyzed in this chapter should also be highlighted. The multi-party system created in 1946 was abolished in 1965 by Institutional Act Number 2, which created a two-party system, with ARENA (Aliança Renovadora Nacional), the ruling party, and MDB (Movimento Democrático Brasileiro) playing the role of the opposition. Until the end of the 1970s, these two political parties were the only ones officially registered and able to run for election. In 1979, however, law number 6767 extinguished both parties and created a multi-party system. ${ }^{11}$ Among other things, the law instituted in 1979 stated that political parties should have the word party - partido in Portuguese - in their names. Therefore, MDB became PMDB (Partido do Movimento Democrático Brasileiro). ARENA, in turn, was recreated by its leaders as the Partido Democrático Social (PDS). Three other parties that obtained registration to run in the 1982 elections, Partido Trabalhista Brasileiro, Partido Democrático Trabalhista and Partido dos Trabalhadores, comprised politicians whose political rights had been revoked during the early years of the dictatorship in addition to other politicians returning from exile. Figure 1 illustrates the timeline of the relevant events and the years in which the mayors of some municipalities were appointed by the regime, while others were elected directly, refereed to as the "treatment period".

\subsubsection{Economic growth and the rise in income inequality}

The military dictatorship period was one of strong economic growth, especially the first half of the regime. It was also a period in which income inequality increased substantially. To understand how this process occurred, it is important to examine the main features of the Brazilian economy during the years of the regime.

During the mandate of the first military president, between 1964 and 1967, with the objective of transforming Brazil into a modern capitalist economy, a series of reforms

\footnotetext{
${ }^{11}$ Available at <http://www.planalto.gov.br/ccivil03/leis/1970-1979/L6767.htm>.
} 


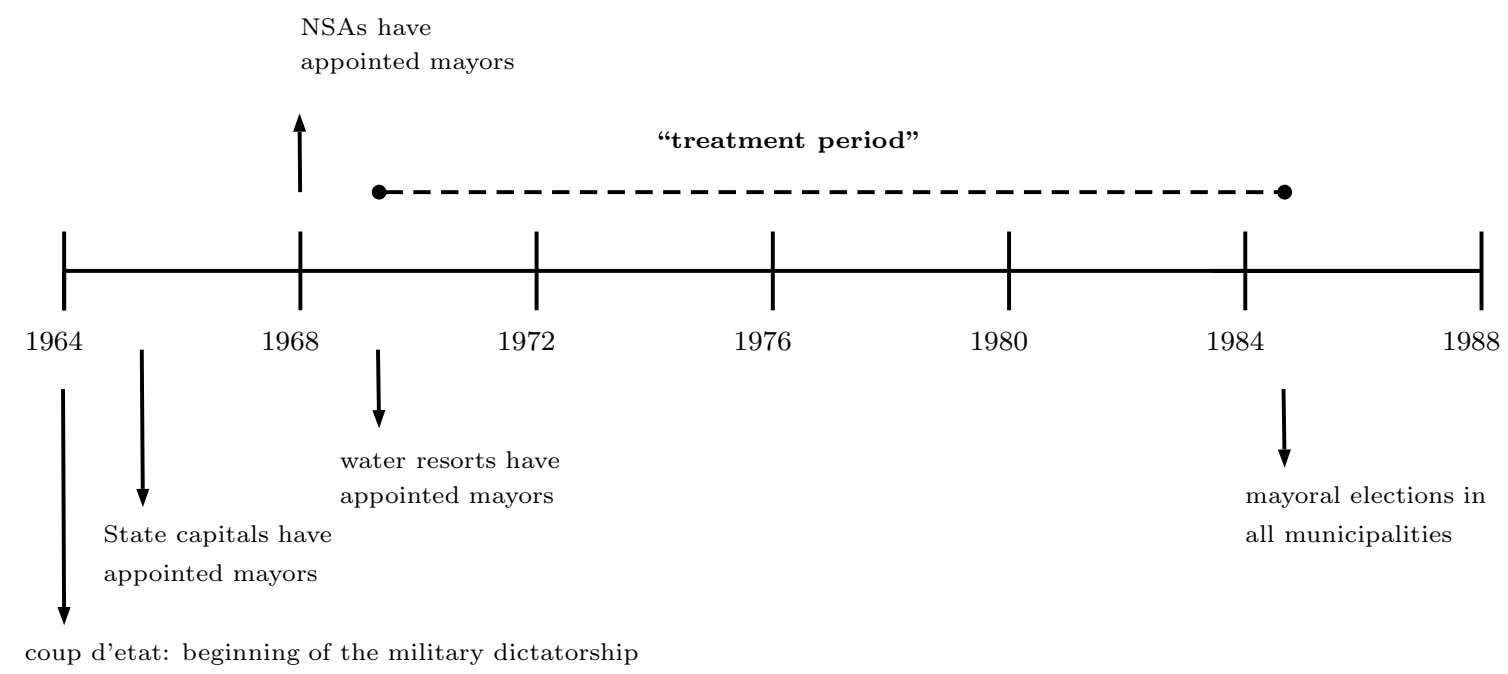

Figure 1: Timeline of the relevant events during the Brazilian dictatorship

aimed at reducing inflation and at modernizing capital markets were implemented. As a result of such reforms and problems associated with import substitution industrialization inherited from the democratic period, the Brazilian economy lost much of its dynamism until 1967.

After 1967, however, as a reflect of the reforms adopted years before, the government was able to adopt an expansionary policy, by increasing credit, especially for housing and durable goods, and by increasing investment in state-managed companies. As a result of this effort together with the state of the world economy, economic growth between 1968 and 1973 was very strong, with the GDP growing at an average rate of over $11 \%$ per year. Most importantly, this growth was achieved with a slightly decrease of the inflation rate. ${ }^{12}$ This was possible for a number of reasons but mainly, and most importantly for the sake of this research, through price and wage control $^{13}$, which disadvantaged the poorer part of the population and increased income inequality (Singer (2014)).

The economic growth in 1964-1973 was followed by an increase in the dependence of the Brazilian economy from foreign economies, especially relating to the import of capital goods and oil. ${ }^{14}$ Therefore, when oil prices rose in 1973, the government was forced to change its economic policy towards a model that decreased dependence on foreign

\footnotetext{
${ }^{12}$ This period became to be known as the "Brazilian Miracle"

${ }^{13}$ Wages were not allowed to rise above certain thresholds established by the federal government

${ }^{14}$ Oil imports between 1967 and 1973 jumped from $59 \%$ of total consumption in the country to $81 \%$ Herman (2005).
} 
economies. Facing political pressure and high liquidity in the international market fuelled by petrodollars, the Brazilian government adopted a non-recessionary adjustment model, encouraging sectors that were identified as the main sources of the external dependency, namely infrastructure, energy, and capital goods (Castro \& Souza (2004)).

Owing to the 1979 oil crisis, it was not possible to continue with non-recessionary adjustment. The cost incurred by the country was high, and despite attempts to prevent it, recessionary adjustment had to be adopted. Between 1981 and 1983, GDP growth was $-2.2 \%$ per year on average. From mid-1984 onwards, Brazil's economy started to grow moderately under a hyperinflation process, which obliged the government to adopt a number of economic plans and measures that contemplated price and wage controls and traditional recessionary measures, increasing income inequalities further still (Castro $(2005))$.

\subsection{Data}

The main dataset used in this chapter was constructed from historical files from the Federal Electoral Authority, the Tribunal Regional Eleitoral, which contains information on mayors appointed during the 1970s and 1980s in Brazil. In addition to this dataset, this chapter also uses data from the 1970, 1980, and 1991 Demographic Censuses ${ }^{15}$ provided by the Instituto Brasileiro de Geografia e Estatística (IBGE), which are used to construct socioeconomic variables at the municipality level. This chapter also uses information on municipalities neighbors in 1970, constructed from the shapefile of Brazilian municipalities in 1970, also provided by the IBGE.

As previously mentioned, three groups of municipalities had appointed mayors between 1967 and 1985: state capitals, municipalities considered to be water resorts, and municipalities located in NSAs. Table 1 presents the number of municipalities classified into each of these categories in 1972, 1976, and 1982, the three municipal elections for which data are available. ${ }^{16}$

\footnotetext{
${ }^{15}$ The Demographic Census that was supposed to be carried out in 1990 was conducted in 1991 because of administrative issues.

${ }^{16}$ As previously mentioned, there was a municipal election in 1970 but data for this election are unavailable. Therefore, it is not possible to credibly identify which municipalities had appointed mayors and why.
} 
Table 1: Municipalities with appointed mayors

\begin{tabular}{lrrr}
\hline \hline & 1972 & 1976 & 1982 \\
\hline NSAs & 100 & 109 & 102 \\
Water resorts & 37 & 34 & 16 \\
State capitals & 24 & 25 & 25 \\
\hline Total & 161 & 168 & 143 \\
\hline \hline
\end{tabular}

Municipalities located in NSAs represent the majority of municipalities that had appointed mayors in the analyzed period, with 100 municipalities being classified into this category in 1972. Between 1972 and 1976, ten other municipalities were classified as such, four in Bahia State, two in Para State, and another four located in four different states. In the same period, one municipality, in Rio de Janeiro State, which was considered to be in an NSA, was reclassified as a water resort. ${ }^{17}$ Between 1976 and 1982, eight new municipalities were considered to be located in an NSA, the majority of them located in Santa Catarina State. In the same period, one municipality considered to be in an NSA in the previous election had direct mayoral elections.

The number of municipalities considered to be water resorts also changed over time. In 1972, 37 municipalities were classified as such. This number decreased to 34 in the 1976 election, as two municipalities were reclassified as located in an NSA, two were reclassified and had mayoral elections, and one that was considered to be located in an NSA was now considered to be a water resort. In 1982, the municipalities classified as water resorts in São Paulo State (and four others in different states) were allowed to elect their mayors by direct elections.

Although not constant in Table 1, the number of state capitals does not change in this period. Table 1 presents an increase in state capitals that had appointed mayors between 1972 and 1976 because Curitiba, the capital of Parana State, elected its mayor directly in 1972. Further, between 1972 and 1976, the capital of Rio de Janeiro State changed from Niteroi to Rio de Janeiro.

To have clearer treatment and control groups, this chapter analyzes only those municipalities that either had appointed mayors in all three mentioned municipal elections or elected

\footnotetext{
${ }^{17}$ The information in this table was obtained from hand-written documents that contain the results of the 1972, 1976, and 1982 municipal elections. Therefore, it is possible that the change in municipality classification is a reflection of mistakes in these documents.
} 
mayors in the same three elections. Municipalities partially disenfranchised, that is, those municipalities that had appointed mayors in only one or two of the referred elections are therefore excluded from this analysis.

\subsection{Empirical strategy}

Identifying the effects of a change in political institutions such as having appointed mayors during almost two decades on income distribution is not straightforward. Municipalities that had appointed mayors were not randomly chosen; they were selected by the federal government for specific reasons and therefore should be expected to be different from the rest of the country in many dimensions. Table 2 presents the baseline characteristics of Brazilian municipalities by different groups. The first column reports the characteristics of all municipalities present in the 1970 Demographic Census. Columns (2) and (3) present the characteristics of those municipalities that had appointed mayors in at least one of the three elections between 1972 and 1982.

Table 2: Mean of the baseline (1970) socioeconomic characteristics

\begin{tabular}{|c|c|c|c|}
\hline & $\begin{array}{c}(1) \\
\text { All } \\
\text { municipalities }\end{array}$ & $\begin{array}{l}\qquad(2) \\
\text { Municipalities } \\
\text { with appointed } \\
\text { mayors }\end{array}$ & $\begin{array}{c}(3) \\
\text { Municipalities } \\
\text { with appointed } \\
\text { mayors (except } \\
\text { state capitals) }\end{array}$ \\
\hline Inequality (Theil index) & 35.12 & 40.19 & 38.19 \\
\hline Share of pop. living in urban areas & 32.16 & 43.99 & 36.17 \\
\hline $\log ($ population $)$ & 9.39 & 10.25 & 9.81 \\
\hline Population density (inhabitants $/ \mathrm{km}^{2}$ ) & 59.55 & 269.60 & 69.08 \\
\hline Share of illiteracy & 43.64 & 30.64 & 32.35 \\
\hline Average years of schooling & 1.39 & 2.27 & 2.01 \\
\hline Income per capita (in minimum wages) & 0.35 & 0.55 & 0.48 \\
\hline $\log ($ number of households) & 7.69 & 8.54 & 8.10 \\
\hline Life expectancy & 51.26 & 53.25 & 53.61 \\
\hline Share of pop. occupied & 30.60 & 31.46 & 31.78 \\
\hline Share of households with sanitation & 4.97 & 10.18 & 8.95 \\
\hline Share of households with piped water & 14.57 & 26.73 & 22.72 \\
\hline Share of households with electricity & 24.00 & 37.24 & 31.72 \\
\hline Share of pop. living in poverty & 83.96 & 70.80 & 73.90 \\
\hline Number of municipalities & 3951 & 172 & 146 \\
\hline
\end{tabular}

As expected, column (2) shows that municipalities with appointed mayors are different in numerous ways from the rest of the country. In particular, they are more urbanized, 
more populated, wealthier, present better measures of schooling, and their citizens have higher life expectancy. Therefore, simply comparing this group of municipalities with the rest of the country would not be possible to assess the effect of having appointed mayors on economic outcomes.

Since state capitals are likely to be different from the rest of the municipalities, column (3) presents the characteristics of municipalities considered to be water resorts and those located in NSAs. This shows that even excluding state capitals, municipalities that had appointed mayors are very different from the rest of the country. Despite this notable difference, however, it is reasonable to believe, based on what has been exposed in previous sections, that these two groups of municipalities were chosen by the federal government to have appointed mayors mainly because of their geographic characteristics (i.e. availability of explorable water and proximity to borders). Figure 2 illustrates this fact by showing the distribution of municipalities that had appointed mayors in at least one of the three elections between 1972 and 1982. This figure shows that, especially for municipalities located in NSAs, the selection was mainly driven by geographic characteristics, namely being located on the border of the country. Although spread over the country, to be considered a water resorts, a municipality had to meet a clear geographical requirement (i.e having explorable water sources). Therefore, to minimize the concern with (political and economic) selection, this chapter focuses its analysis on municipalities located in NSAs and those considered to be water resorts. By doing so, the issue of the selection of municipalities based on political and economic characteristics is substantially reduced. In other words, by using this subset of municipalities that, arguably, were selected mainly by their geographic characteristics, the main source of endogeneity becomes known and, therefore, it is possible to develop a strategy to deal with it. 


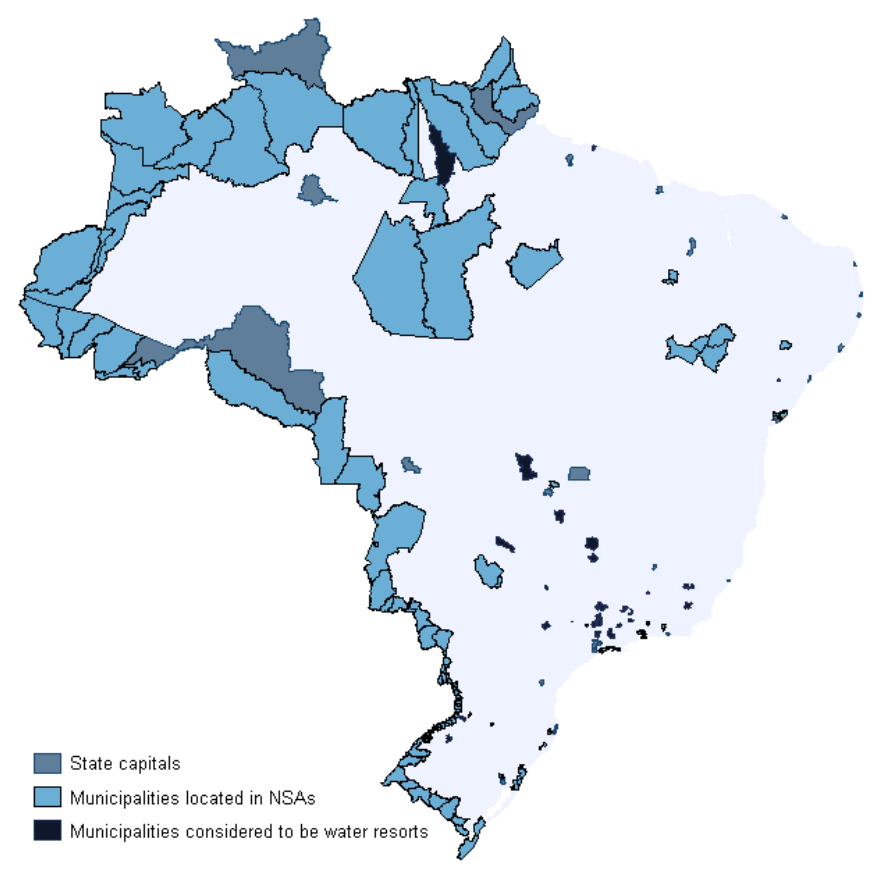

Figure 2: Municipalities with appointed mayors

Even by restricting the analysis to this subset of municipalities, it is still not possible to simply compare municipalities with appointed mayors with the rest of the country to assess the effect of this variation in political institutions. An alternative approach would be to use geography as an instrument for disenfranchised municipalities (i.e. a dummy equal to one if the municipality is in the border and/or a measure of the amounts of explorable water in the municipality). The issue with this strategy, however, is the well documented influence of geography on economic institutions and economic outcomes, thereby violating the exclusion restriction. ${ }^{18}$

The empirical strategy employed in this chapter resembles that proposed by Keele, Titiunik \& Zubizarreta (2015) and used by Larreguy, Marshall \& Snyder (2014), which can be understood as a combination of geographic regression discontinuity (GRD) design with matching techniques. By claiming that one of the main sources of selection is the municipality's location, the strategy employed compares each municipality that had appointed mayors with its most similar neighbor in terms of the Mahalanobis distance.

As for non-geographic regression discontinuity designs, causal effects are identified under the assumption that potential outcomes are continuous in all other variables at the geographic discontinuity. Although it is not quite necessary, achieving balance across the

\footnotetext{
${ }^{18}$ For more on the debate about the relation between geography and economic institutions, see (Acemoglu, Johnson \& Robinson (2002)).
} 


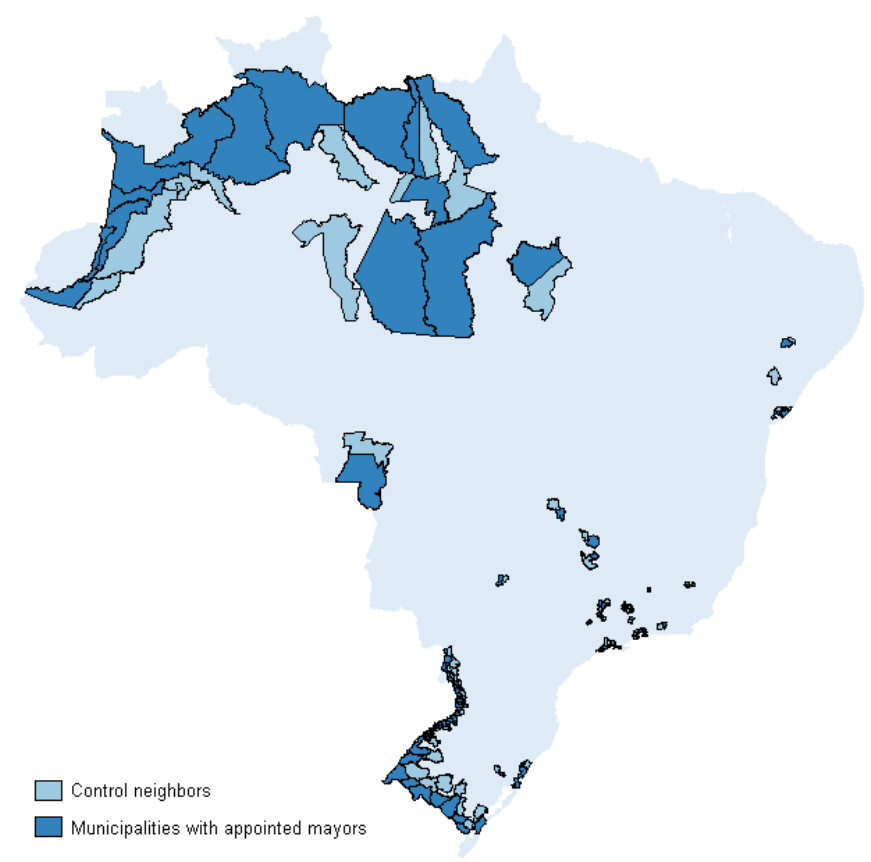

Figure 3: Municipalities with appointed mayors in the sample and neighbors used as the control group

treatment and control groups is sufficient for continuity to hold Imbens \& Lemieux (2008). This motivates the decision to match over a set of covariates and select the most similar non-treated municipalities in terms of the Mahalanobis distance.

More specifically, the construction of the sample entails the following procedure:

1. Identify potential matches. For each municipality with appointed mayors $i$, the set of possible matches is restricted to the set of neighboring municipalities $j$ that had mayors elected directly in 1972, 1976, and 1982. This set of potential matching is denoted $J(i)$.

2. Calculate the Mahalanobis distance $D\left(X_{i}, X_{j}\right)=\sqrt{\left(X_{i}-X_{j}\right)^{\prime} C^{-1}\left(X_{i}-X_{j}\right)}$ between municipality $i$ and each possible match $j \in J(i)$ using the vector $X_{i}$ of 14 covariates and the full sample covariance matrix $C$.

3. Finally, for each treated municipality $i$, choose the control municipality taking the nearest match in the set $J(i)$.

Figure 3 illustrates the sample from the algorithm described above.

With the sample constructed, Equation 1.1 is estimated to assess the effect of appointed 
mayors on the economic outcome of interest $y$ in the municipality $i$ :

$$
y_{i}=\delta \cdot y_{i, 1970}+\gamma \cdot \text { appointed }_{i}+\mathbf{X}_{\mathbf{i}} \beta+\varepsilon_{i}
$$

where appointed is a dummy variable that takes the value one for municipalities that had appointed mayors in the analyzed period. Since this research is interested in the changes in economic outcomes $y_{i}$ after a municipality had appointed mayors, the baseline variable $y_{i, 1970}$ is also included in the regression. Although the results from balance checks reported in Section 1.5.1 show that control and treatment groups are balanced in baseline covariates constructed from the 1970 Demographic Census, the complete specification of Equation 1.1 is estimated including the vector of covariates $\mathbf{X}_{\mathbf{i}}$ as a control.

Equation 1.1 is run for the measures of inequality constructed from the 1980 and 1991 Demographic Censuses. Since the municipalities in the treatment group had appointed mayors between the end of the 1960s and 1985, measuring the effects of appointed mayors with minimum noise and avoiding confounding the effects with, for instance, possible heterogeneous effects of redemocratization among treatment and control groups would ideally require estimating the effects on inequality (or any other possible outcomes of interest) immediately after the treatment has ended (i.e. immediately after redemocratization in 1985 when all municipalities had direct mayoral elections). Unfortunately, this is not possible since detailed socioeconomic data at the municipality level such as income distribution measures were only collected in 1980 and 1991. Therefore, to provide evidence that the results are indeed driven by having appointed mayors, this research tests for differences in economic outcomes both in 1980 and in 1991. If appointed mayors affect the income distribution, one should expect to see this effect increase over time. Moreover, it seems unreasonable to believe that redemocratization would have different effects in municipalities in the treatment and control groups, especially in terms of redistribution and in such a short period. If anything, using measures of income inequality in 1991 introduces some noise into the estimates.

One concern with the empirical strategy described is with confounding treatments, a concern that naturally arises with strategies that rely on geography. By comparing municipalities in specific locations with their neighbors, the effect identified may not only be the effect of having appointed mayors per se but also be the effect of being in that 
specific geographic area. In other words, proximity to a border or having large amounts of explorable water may explain the findings presented in this chapter. To provide evidence that this is not the case, a placebo exercise comparing non-treated neighbors as if they were treated with their own non-treated neighbors is reported in Section 1.6.

To show that the main results are robust to the matching algorithm, in appendix A the same exercises of the following section are reproduced; however, instead of using the matching algorithm to identify each disenfranchised municipality's closest neighbor, all non-disenfranchised neighbors are used as counterfactual. In contrast to employing a combination of geographic regression discontinuity design and matching, balance among the control and treatment groups is not achieved. The main results, however, are qualitatively unchanged when municipality-level controls are included. The results are presented in Tables 25-27. Figure 11 illustrates the sample constructed without the matching algorithm.

\subsection{Results}

\subsubsection{Balance check}

This section begins by showing evidence that the empirical strategy described in the previous section results in a control group that is similar to the group of treated municipalities in a number of relevant predetermined characteristics. Table 3 reports the same statistics presented in Table 2. In contrast to that table, however, it shows the mean characteristics only for the subset of municipalities that had appointed mayors considered in the analysis (i.e. state capitals and partially disenfranchised municipalities are not considered). The comparison group also differs from that in Table 2 by including only the closest neighbor of each disenfranchised municipality measured by the Mahalanobis distance.

As seen in columns (1) and (2), even when restricting the comparison to municipalities with appointed mayors and their closest neighbors, the former present higher average measures of urbanization, wealth, schooling, inequality, and population size. These differences, however, are now not statistically significant at the usual levels.

To ensure that this balance in covariates is not simply a mechanical result of the matching algorithm implemented, Table 4 reproduces the statistics and tests reported in the 
Table 3: Balance check of the baseline characteristics between municipalities with appointed mayors and the control group

\begin{tabular}{lccc}
\hline & $\begin{array}{c}(1) \\
\text { Mun. with } \\
\text { appointed mayors }\end{array}$ & $\begin{array}{c}(2) \\
\text { Control } \\
\text { municipalities }\end{array}$ & $\begin{array}{c}(3) \\
\text { p-value }\end{array}$ \\
\hline Inequality (Theil index) & 38.04 & 36.97 & 0.51 \\
Share of pop. living in urban areas & 32.69 & 29.65 & 0.41 \\
log(population) & 9.98 & 9.83 & 0.35 \\
Population density (inhabitants $\left./ \mathrm{km}^{2}\right)$ & 65.24 & 57.28 & 0.75 \\
Share of illiteracy & 29.65 & 31.89 & 0.33 \\
Average years of schooling & 2.15 & 1.95 & 0.13 \\
Income per capita (in minimum wages) & 0.49 & 0.43 & 0.12 \\
Log(number of households) & 8.27 & 8.11 & 0.35 \\
Life expectancy & 54.07 & 53.79 & 0.68 \\
Share of pop. occupied & 32.70 & 31.54 & 0.18 \\
Share of households with sanitation & 8.91 & 1.18 & 0.48 \\
Share of households with piped water & 22.98 & 28.45 & 0.36 \\
Share of households with electricity & 31.48 & 77.54 & 0.44 \\
Share of pop. living in poverty & 73.70 & 66 & 0.14 \\
\hline Number of municipalities & 81 & - \\
\hline
\end{tabular}

previous table using samples constructed from a slightly different matching algorithm. For each one of the 14 covariates of the vector $\mathbf{X}_{\mathbf{i}}$, a sample was constructed using the remaining 13 covariates to match each treated municipality with the closest neighbor. More specifically, the procedure for each covariate $x_{s} \in \mathbf{X}_{\mathbf{i}}$ is as follows:

1. Identify the set $J(i)$ of potential matches for each municipality with appointed mayors $i$.

2. Define the set $X_{i,-s}$ that contains all the covariates except for $x_{s}$.

3. Calculate the Mahalanobis distance $D\left(X_{i,-s}, X_{j,-s}\right)$ between municipality $i$ and each possible municipality match $j \in J(i)$ using the vector $X_{i,-s}$ of the remaining 13 covariates and the full sample covariance matrix $C$.

4. For each treated municipality $i$, choose the control municipality by taking the nearest match in the set $J(i)$.

This procedure results in 14 potentially different samples with which it is possible to test for the differences in each of the covariates between the treatment and control groups. The results presented in Table 4 show that the covariates are balanced, except for per capita 
income, which is slightly higher in treated municipalities, with the difference significant at the $10 \%$ level. The results not only show that the balance between the treatment and control groups is not simply a mechanical result of the matching algorithm implemented but also suggest that the treatment and control groups might be balanced in other relevant (unobservable) characteristics.

Table 4: Balance check of the baseline characteristics between municipalities with appointed mayors and the control group (using $\mathrm{N}-1$ covariates to match)

\begin{tabular}{|c|c|c|c|c|c|}
\hline & $\begin{array}{c}\text { Mun. } \\
\text { mean } \\
(1)\end{array}$ & $\begin{array}{l}\text { inted mayors } \\
\text { obs } \\
(2)\end{array}$ & $\begin{array}{c}\text { Contr } \\
\text { mean } \\
(3)\end{array}$ & $\begin{array}{l}\text { icipalities } \\
\text { obs } \\
(4)\end{array}$ & $\begin{array}{c}\text { p-value } \\
(5)\end{array}$ \\
\hline Inequality (Theil index) & 38.04 & 81 & 37.14 & 65 & 0.59 \\
\hline Share of pop. living in urban areas & 32.69 & 81 & 29.31 & 67 & 0.35 \\
\hline $\log ($ population $)$ & 9.98 & 81 & 9.84 & 66 & 0.38 \\
\hline Population density (inhabitants $/ \mathrm{km}^{2}$ ) & 65.24 & 81 & 93.20 & 66 & 0.52 \\
\hline Share of illiteracy & 29.65 & 81 & 31.80 & 63 & 0.37 \\
\hline Average years of schooling & 2.15 & 81 & 1.97 & 63 & 0.21 \\
\hline Income per capita (in minimum wages) & 0.49 & 81 & 0.42 & 64 & 0.06 \\
\hline Log(number of households) & 8.27 & 81 & 8.12 & 66 & 0.38 \\
\hline Life expectancy & 54.07 & 81 & 53.99 & 64 & 0.91 \\
\hline Share of pop. occupied & 32.70 & 81 & 31.54 & 65 & 0.18 \\
\hline Share of households with sanitation & 8.91 & 81 & 6.52 & 68 & 0.31 \\
\hline Share of households with piped water & 22.98 & 81 & 19.45 & 67 & 0.35 \\
\hline Share of households with electricity & 31.48 & 81 & 29.67 & 67 & 0.65 \\
\hline Share of pop. living in poverty & 73.70 & 81 & 77.60 & 67 & 0.13 \\
\hline
\end{tabular}

Notes: each line presents the statistics of the test of the mean difference between the municipalities with appointed mayors and the control group. To construct the control group in this exercise, each municipality was matched to its most similar neighbor according to a set of N-1 covariates and the control group, with the omitted covariate being the variable tested for the difference in each line. Each line, therefore, may have a different control group.

\subsubsection{Effects on income distribution}

This section reports the main results of this chapter, the effect of having appointed mayors for almost two decades on income distribution. Figure 4 illustrates the evolution of the Theil index in municipalities that had appointed mayors during the dictatorship and in neighboring control municipalities. In both groups of municipalities, inequality increased substantially during the years of the military dictatorship, consistent with the discussion in the previous sections.

Figure 4 also evidences that the increase in inequality is accentuated in disenfranchised municipalities. Table 5 formalizes these results by showing the estimates of Equation 1.1. The dependent variable appointed mayor is a dummy variable that takes the value one if the municipality had appointed mayors in all three municipal elections between 1972 


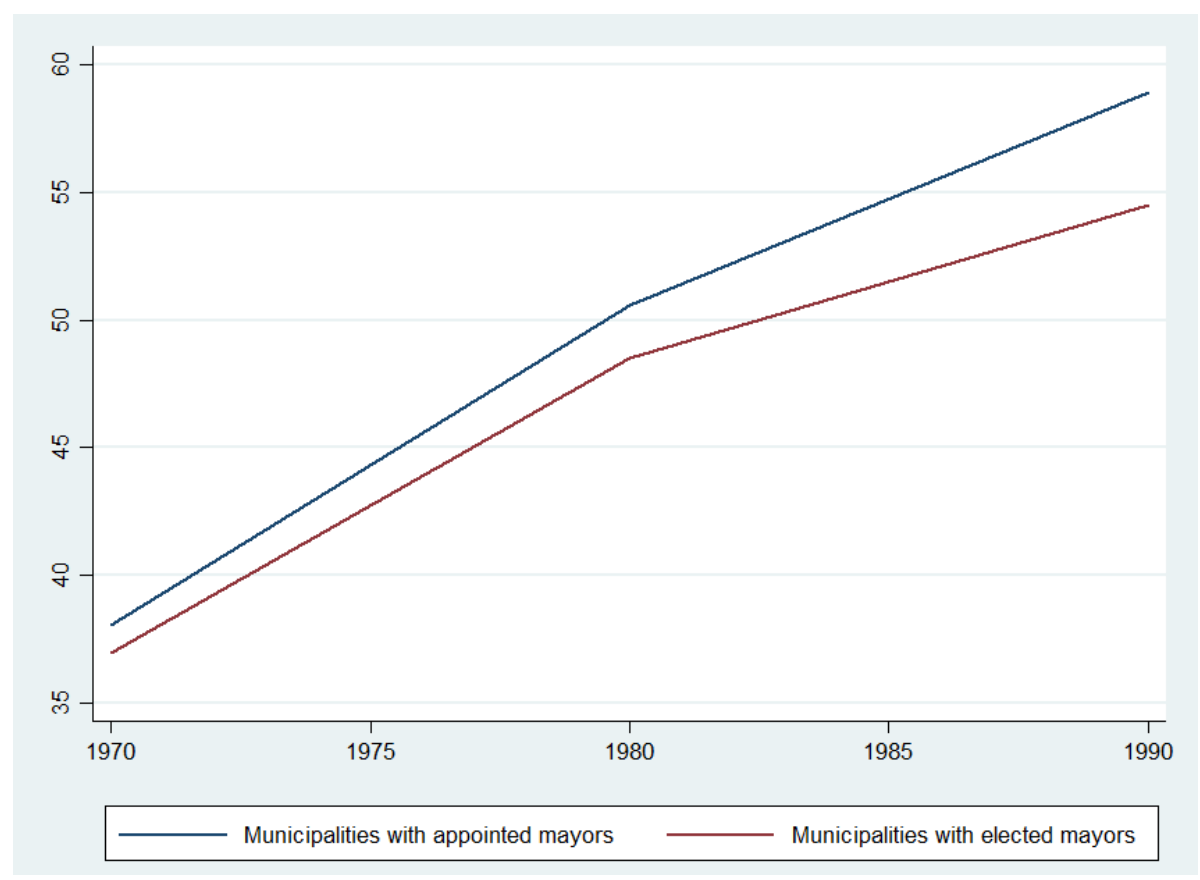

Figure 4: Theil index in municipalities with appointed and with elected mayors

and 1982 and zero if the municipality had mayors elected democratically. The dependent variable is the Theil index measured in 1980 and 1991 and it is given by:

$$
\text { Theil index }=\frac{1}{N} \sum_{i=1}^{N}\left(\frac{x_{i}}{\bar{x}} \cdot \ln \frac{x_{i}}{\bar{x}}\right)
$$

where $x_{i}$ is the income of each individual and $\bar{x}$ is the mean of $x$. If everyone has the same income, then $x_{i}=\bar{x}, \forall i$ and the Theil index equals zero. On the contrary, if one person has all the income, the index equals $\ln (N)$. The index is normalized to be in the interval $[0,1]$.

Although the balance checks show that the control and treatment groups are balanced in a number of dimensions (including inequality), the baseline Theil index is included in all regressions to ensure that the variation in the index from one period to another is being estimated. Columns (1) and (3) report the estimates of the effect of having appointed mayors on the Theil index in 1980 and 1991, respectively, without including the baseline controls. Columns (2) and (4) present the results of similar regressions but with the inclusion of the vector of baseline controls $\mathbf{X}_{\mathbf{i}}$.

Table 5 shows that the difference in the increase in the Theil index between municipalities 
Table 5: Effect on the Theil index

Dependent variable: Theil index in year $t$; covariates measured in $t=1970$

\begin{tabular}{|c|c|c|c|c|}
\hline & \multicolumn{2}{|c|}{$\mathrm{t}=1980$} & \multicolumn{2}{|c|}{$\mathrm{t}=1991$} \\
\hline & (1) & $(2)$ & $(3)$ & $(4)$ \\
\hline \multirow[t]{2}{*}{ Appointed mayor } & 1.3974 & 1.3327 & $4.1105^{*}$ & $4.3194^{* *}$ \\
\hline & $(1.9138)$ & $(1.8442)$ & $(2.1142)$ & $(2.0024)$ \\
\hline \multirow{2}{*}{ Inequality (Theil index) } & $0.6540^{* * *}$ & $0.8013^{* * *}$ & $0.2671^{* * *}$ & $0.4151^{* *}$ \\
\hline & $(0.0888)$ & $(0.1507)$ & $(0.0955)$ & $(0.1608)$ \\
\hline \multirow[t]{2}{*}{ Share of pop. living in urban areas } & & 0.1521 & & 0.1001 \\
\hline & & $(0.1023)$ & & $(0.0836)$ \\
\hline \multirow[t]{2}{*}{$\log ($ population $)$} & & -9.8572 & & 22.9578 \\
\hline & & $(15.9397)$ & & $(16.4989)$ \\
\hline \multirow[t]{2}{*}{ Population density } & & -0.0076 & & -0.0035 \\
\hline & & $(0.0083)$ & & $(0.0069)$ \\
\hline \multirow[t]{2}{*}{ Share of illiteracy } & & $-0.3938^{* *}$ & & 0.1045 \\
\hline & & $(0.1700)$ & & $(0.2320)$ \\
\hline \multirow[t]{2}{*}{ Average years of schooling } & & $-6.0890^{*}$ & & 0.0194 \\
\hline & & $(3.1299)$ & & $(3.9098)$ \\
\hline \multirow[t]{2}{*}{ Income per capita (in minimum wages) } & & -11.9974 & & $-21.8445^{*}$ \\
\hline & & $(13.1049)$ & & $(12.9617)$ \\
\hline \multirow[t]{2}{*}{ Log(number of households) } & & 10.8757 & & -21.3136 \\
\hline & & $(15.8127)$ & & $(16.7353)$ \\
\hline \multirow[t]{2}{*}{ Life expectancy } & & 0.3571 & & $1.2109^{* * *}$ \\
\hline & & $(0.3612)$ & & $(0.4240)$ \\
\hline \multirow[t]{2}{*}{ Share of pop. occupied } & & -2.4322 & & 5.3908 \\
\hline & & $(21.1955)$ & & $(26.1852)$ \\
\hline \multirow[t]{2}{*}{ Share of households with sanitation } & & $0.2134^{* *}$ & & $0.1862^{*}$ \\
\hline & & $(0.0984)$ & & $(0.0978)$ \\
\hline \multirow[t]{2}{*}{ Share of households with piped water } & & $-0.2062^{* *}$ & & -0.1032 \\
\hline & & $(0.0936)$ & & $(0.0897)$ \\
\hline \multirow[t]{2}{*}{ Share of households with electricity } & & $-0.2870^{* *}$ & & -0.0517 \\
\hline & & $(0.1294)$ & & $(0.1227)$ \\
\hline \multirow[t]{2}{*}{ Share of pop. in poverty } & & -0.3860 & & -0.1497 \\
\hline & & $(0.2480)$ & & $(0.2127)$ \\
\hline Observations & 147 & 147 & 147 & 147 \\
\hline R-squared & 0.24 & 0.41 & 0.07 & 0.28 \\
\hline
\end{tabular}

Robust standard errors in parentheses: ${ }^{*} p<0.10,{ }^{* *} p<0.05,{ }^{* * *} p<0.01$ 
with appointed mayors and the control group, although positive, is not significant in 1980 . The difference estimated in 1991, however, is not only positive but highly significant. Further, both sets of results are robust to the inclusion of municipality-level controls. Indeed, the point estimates do not change with the inclusion of these controls; they only become more precise, providing further evidence the sample is fairly well balanced. The results show that on average municipalities that had appointed mayors present a Theil index around 4 points higher than their neighbors in $1991 .{ }^{19}$ In the same period, the Theil index in Brazil went from 68 in 1970 to 78 in 1991. That is to say, having mayors appointed by the dictatorship regime is associated with an increase in inequality similar to $40 \%$ of the rise the country experienced during those two decades.

Although this research focuses on studying the presence of elite capture by measuring income inequality, it is convenient to look at how other variables evolved during this period in disenfranchised municipalities compared with their control neighbors. Tables 28 and 29 in appendix A show that the vast majority of the other socioeconomic variables did not present significant differences between the treatment and control groups in 1980 and 1991. The only exceptions are the number of households and size of population, which are larger in the treated municipalities, suggesting that not only inequality increased in disenfranchised municipalities but they also become larger compared with the control group.

The results presented thus far show that having appointed mayors is associated with a significant increase in inequality. However, this increase in inequality cannot yet be interpreted as the presence of elite capture. To shed light on the reasons behind the effects reported in the previous table, Table 6 presents results of the estimates of Equation 1.1 on the other measures of income distribution. The dependent variables used in these regressions were constructed from the 1991 Demographic Census and show the share of the municipality income earned by different quintiles of the population. In the first column, the dependent variable is the share of income earned by the $20 \%$ poorest; in the second column, the share earned by the $40 \%$ poorest; in the third column, the share earned by the $60 \%$ poorest; in the fourth, the share earned by the $20 \%$ richest (or one minus the share earned by the $80 \%$ poorest); and in the last column, the share earned by the $10 \%$ richest (or one minus the share earned by the $90 \%$ poorest).

As discussed in Section 1.2, the understanding in the economic history literature is that the

\footnotetext{
${ }^{19}$ in 1970, as seen in Table 3, this difference was balanced between the two groups.
} 
concentration of wealth in this period was mainly through a decrease in real wages, which ended up punishing the lower classes of the population to a greater extent. Therefore, if the increase in inequality in disenfranchised municipalities was simply a magnification of the distributional effects that took place across the country, strong negative effects on the share of the income earned by the poorest should be expected. However, according to the estimates in Table 6, inequality increased in municipalities that had appointed mayors more than it did in the control group mainly due to an increase in the share of income earned by the richest. In other words, the situation of the poor in municipalities that had appointed mayors and in neighboring municipalities changed similarly between 1970 and 1991. In the same period, the situation of the rich, on the contrary, improved dramatically in municipalities that had appointed mayors compared with neighboring municipalities.

These results are consistent with a story of elite capture in these municipalities, especially considering that this was a period of intense investment by the central government and that, from the evidence documented in the political economy literature, ${ }^{20}$ these municipalities were more likely to receive (larger) federal investment because of their political alignment. Ideally, this hypothesis could be better investigated by looking at expenditure data. However, as such data are unavailable, this research relies on the latter findings and on the results presented in Tables 28 and 29 in the appendix A, which imply that disenfranchised municipalities increased more during this period and are, therefore, consistent with the hypothesis that these municipalities received more investment.

\footnotetext{
${ }^{20}$ See Brollo \& Nannicini (2012); Solé-Ollé \& Sorribas-Navarro (2008); Khemani (2007); Arulampalam et al. (2009); and Leão (2011).
} 
Table 6: Effect on income distribution in 1991

\begin{tabular}{|c|c|c|c|c|c|}
\hline & $\begin{array}{c}(1) \\
\text { Share of } \\
\text { income } \\
\text { earned by } \\
\text { the } 20 \% \\
\text { poorest }\end{array}$ & $\begin{array}{c}(2) \\
\text { Share of } \\
\text { income } \\
\text { earned by } \\
\text { the } 40 \% \\
\text { poorest }\end{array}$ & $\begin{array}{c}(3) \\
\text { Share of } \\
\text { income } \\
\text { earned by } \\
\text { the } 60 \% \\
\text { poorest }\end{array}$ & $\begin{array}{c}(4) \\
\text { Share of } \\
\text { income } \\
\text { earned by } \\
\text { the } 20 \% \\
\text { richest }\end{array}$ & $\begin{array}{c}(5) \\
\text { Share of } \\
\text { income } \\
\text { earned by } \\
\text { the } 10 \% \\
\text { richest }\end{array}$ \\
\hline Appointed mayor & $\begin{array}{l}-0.2713^{*} \\
(0.1620)\end{array}$ & $\begin{array}{c}-0.7943^{* *} \\
(0.3361)\end{array}$ & $\begin{array}{c}-1.4112^{* *} \\
(0.5498)\end{array}$ & $\begin{array}{l}2.0369^{* *} \\
(0.8104)\end{array}$ & $\begin{array}{l}2.2260^{* *} \\
(0.9508)\end{array}$ \\
\hline Inequality (Theil index) & $\begin{array}{c}-0.0134 \\
(0.0152)\end{array}$ & $\begin{array}{l}-0.0497 \\
(0.0307)\end{array}$ & $\begin{array}{c}-0.1020^{* *} \\
(0.0479)\end{array}$ & $\begin{array}{c}0.1631^{* *} \\
(0.0674)\end{array}$ & $\begin{array}{c}0.1548^{*} \\
(0.0824)\end{array}$ \\
\hline $\begin{array}{l}\text { Share of pop. living in urban } \\
\text { areas }\end{array}$ & -0.0080 & -0.0258 & $-0.0536^{* *}$ & $0.0855^{* *}$ & $0.0982^{* *}$ \\
\hline & $(0.0079)$ & $(0.0156)$ & $(0.0249)$ & $(0.0371)$ & $(0.0432)$ \\
\hline Log(population) & $\begin{array}{c}-1.3292 \\
(1.1748)\end{array}$ & $\begin{array}{l}-3.5221 \\
(2.6386)\end{array}$ & $\begin{array}{l}-6.6941 \\
(4.3120)\end{array}$ & $\begin{array}{c}10.0303 \\
(6.3429)\end{array}$ & $\begin{array}{c}9.5739 \\
(7.7164)\end{array}$ \\
\hline Population density & $\begin{array}{c}0.0004 \\
(0.0006)\end{array}$ & $\begin{array}{c}0.0010 \\
(0.0013)\end{array}$ & $\begin{array}{c}0.0021 \\
(0.0022)\end{array}$ & $\begin{array}{l}-0.0027 \\
(0.0031)\end{array}$ & $\begin{array}{c}-0.0028 \\
(0.0037)\end{array}$ \\
\hline Share of illiteracy & $\begin{array}{c}-0.0534^{* * *} \\
(0.0200)\end{array}$ & $\begin{array}{c}-0.0952^{* *} \\
(0.0366)\end{array}$ & $\begin{array}{r}-0.1355^{* *} \\
(0.0581)\end{array}$ & $\begin{array}{c}0.1526^{*} \\
(0.0878)\end{array}$ & $\begin{array}{c}0.1100 \\
(0.1077)\end{array}$ \\
\hline Average years of schooling & $\begin{array}{c}-0.5164^{*} \\
(0.3033)\end{array}$ & $\begin{array}{l}-0.8055 \\
(0.6161)\end{array}$ & $\begin{array}{c}-0.8791 \\
(1.0326)\end{array}$ & $\begin{array}{c}0.1118 \\
(1.5561)\end{array}$ & $\begin{array}{l}-1.1463 \\
(1.8527)\end{array}$ \\
\hline $\begin{array}{l}\text { Income per capita (in minimum } \\
\text { wages) }\end{array}$ & $2.0793^{*}$ & $4.4765^{*}$ & $7.4798^{*}$ & $-10.1511^{*}$ & -9.1960 \\
\hline & $(1.1607)$ & $(2.4255)$ & $(3.8631)$ & $(5.4541)$ & $(6.3424)$ \\
\hline Log(number of households) & $\begin{array}{c}1.0985 \\
(1.1984)\end{array}$ & $\begin{array}{c}3.0327 \\
(2.6896)\end{array}$ & $\begin{array}{c}5.9493 \\
(4.4027)\end{array}$ & $\begin{array}{l}-9.3118 \\
(6.4713)\end{array}$ & $\begin{array}{c}-9.0531 \\
(7.8648)\end{array}$ \\
\hline Life expectancy & $\begin{array}{c}-0.1131^{\text {*** }} \\
(0.0345)\end{array}$ & $\begin{array}{c}-0.2494^{* * *} \\
(0.0727)\end{array}$ & $\begin{array}{c}-0.4091^{* * *} \\
(0.1160)\end{array}$ & $\begin{array}{c}0.5816^{* * *} \\
(0.1666)\end{array}$ & $\begin{array}{c}0.6056^{* * *} \\
(0.1914)\end{array}$ \\
\hline Share of pop. occupied & $\begin{array}{l}-1.2846 \\
(1.9954)\end{array}$ & $\begin{array}{l}-3.0793 \\
(3.9446)\end{array}$ & $\begin{array}{l}-5.0793 \\
(6.3587)\end{array}$ & $\begin{array}{c}5.7785 \\
(9.5255)\end{array}$ & $\begin{array}{c}1.6415 \\
(11.9249)\end{array}$ \\
\hline $\begin{array}{l}\text { Share of households with } \\
\text { sanitation }\end{array}$ & -0.0074 & -0.0212 & -0.0447 & $0.0786^{*}$ & $0.0944^{* *}$ \\
\hline & $(0.0072)$ & $(0.0164)$ & $(0.0290)$ & $(0.0421)$ & $(0.0472)$ \\
\hline $\begin{array}{l}\text { Share of households with piped } \\
\text { water }\end{array}$ & 0.0107 & 0.0218 & 0.0379 & -0.0588 & $-0.0800^{*}$ \\
\hline & $(0.0067)$ & $(0.0141)$ & $(0.0242)$ & $(0.0390)$ & $(0.0482)$ \\
\hline $\begin{array}{l}\text { Share of households with } \\
\text { electricity }\end{array}$ & -0.0028 & 0.0023 & 0.0064 & 0.0070 & 0.0368 \\
\hline & $(0.0081)$ & $(0.0180)$ & $(0.0319)$ & $(0.0508)$ & $(0.0613)$ \\
\hline Share of pop. in poverty & $\begin{array}{c}0.0164 \\
(0.0201)\end{array}$ & $\begin{array}{c}0.0320 \\
(0.0395)\end{array}$ & $\begin{array}{c}0.0516 \\
(0.0627)\end{array}$ & $\begin{array}{l}-0.0594 \\
(0.0894)\end{array}$ & $\begin{array}{c}-0.0273 \\
(0.1037)\end{array}$ \\
\hline Observations & 147 & 147 & 147 & 147 & 147 \\
\hline R-squared & 0.24 & 0.29 & 0.31 & 0.30 & 0.25 \\
\hline
\end{tabular}

Robust standard errors in parentheses: ${ }^{*} p<0.10,{ }^{* *} p<0.05,{ }^{* * *} p<0.01$ 


\subsection{Placebo exercise}

Since part of the empirical strategy employed in this chapter relies on geography, one possible concern is that the effects documented in the previous sections are not (entirely) related to having appointed mayors but are (also) a result of being in a specific geographical area. This section reports the results of a placebo exercise conducted to reject this hypothesis. The exercise considers as treated all non-disenfranchised neighbors of disenfranchised municipalities (considered in the previous analysis) and compares them with their closest non-disenfranchised neighbors, using a matching algorithm similar to that described in Section 1.4. ${ }^{21}$

If the effect documented in the previous section is (partially) driven by being close to the border of the country - in the case of municipalities located in NSAs - or in an area with large amounts of explorable water - in the case of municipalities considered to be water resorts - similar results should be expected when estimating equation 1.1 in this particular sample. This would not be the case in the unlikely hypothesis that the effect associated with being in a specific geographic area changes discretely. In such a scenario, it would be impossible to disentangle both effects with the strategy employed.

Figure 5 illustrates the placebo exercise. Non-disenfranchised neighbors of disenfranchised municipalities are considered to be treated in this case. A similar matching algorithm is then carried out with their non-disenfranchised neighbors to identify the closest neighbor to be used as the control.

To provide evidence that the strategy employed is able to construct a placebo group that is similar to its respective control group, Table 7 reports the results of a balance check exercise, similar to that in Table 3 for the main sample. The results show that the only variable that is not balanced across the placebo and control group is the share of population living in poverty. All the other covariates have a non-significant difference between both groups.

Tables 8 and 9 reproduce the main regression of the chapter using the placebo sample described above. There is no significant effect in the Theil index measured in 1980 and 1991,

\footnotetext{
${ }^{21} \mathrm{~A}$ more natural alternative would be to consider as treated only the closest neighbor of each treated municipality. This alternative, however, would result in a smaller sample, which could lead to nonsignificant results due to low power.
} 


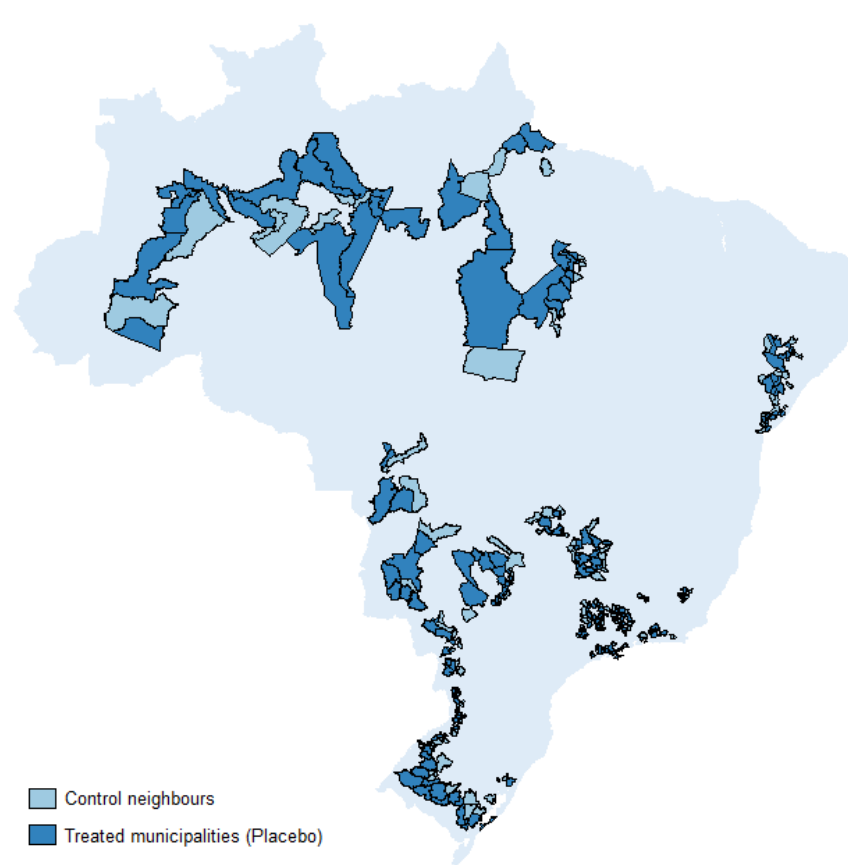

Figure 5: Placebo exercise: Treated municipalities and neighbors used as the control group

Table 7: Placebo: balance check of the baseline characteristics between treated municipalities and the control group

\begin{tabular}{lccc}
\hline & $(1)$ & $(2)$ & $(3)$ \\
& Placebo & Control & p-value \\
\hline Inequality (Theil index) & 36.69 & 36.92 & 0.85 \\
Share of pop. living in urban areas & 31.49 & 28.67 & 0.15 \\
$\log$ (population) & 9.49 & 9.47 & 0.86 \\
Population density (inhabitants/km 2$)$ & 47.62 & 63.67 & 0.51 \\
Share of illiteracy & 37.08 & 37.16 & 0.96 \\
Average years of schooling & 1.67 & 1.65 & 0.80 \\
Income per capita (in minimum wages) & 0.43 & 0.39 & 0.10 \\
Log(number of households) & 7.79 & 7.78 & 0.90 \\
Life expectancy & 52.33 & 52.43 & 0.83 \\
Share of pop. occupied & 31.04 & 30.92 & 0.78 \\
Share of households with sanitation & 7.46 & 6.68 & 0.61 \\
Share of households with piped water & 19.92 & 17.81 & 0.35 \\
Share of households with electricity & 28.65 & 27.11 & 0.55 \\
Share of pop. living in poverty & 77.87 & 80.73 & 0.10 \\
\hline Number of municipalities & 195 & 133 & - \\
\hline
\end{tabular}


nor in the share of income earned by different percentiles of the population, strengthening the hypothesis that the effect is unrelated to geographic characteristics and rather associated with the regime appointing mayors for almost two decades.

Table 8: Placebo: effect on the Theil index

Dependent variable: Theil index in year $t$; covariates measured in $t=1970$

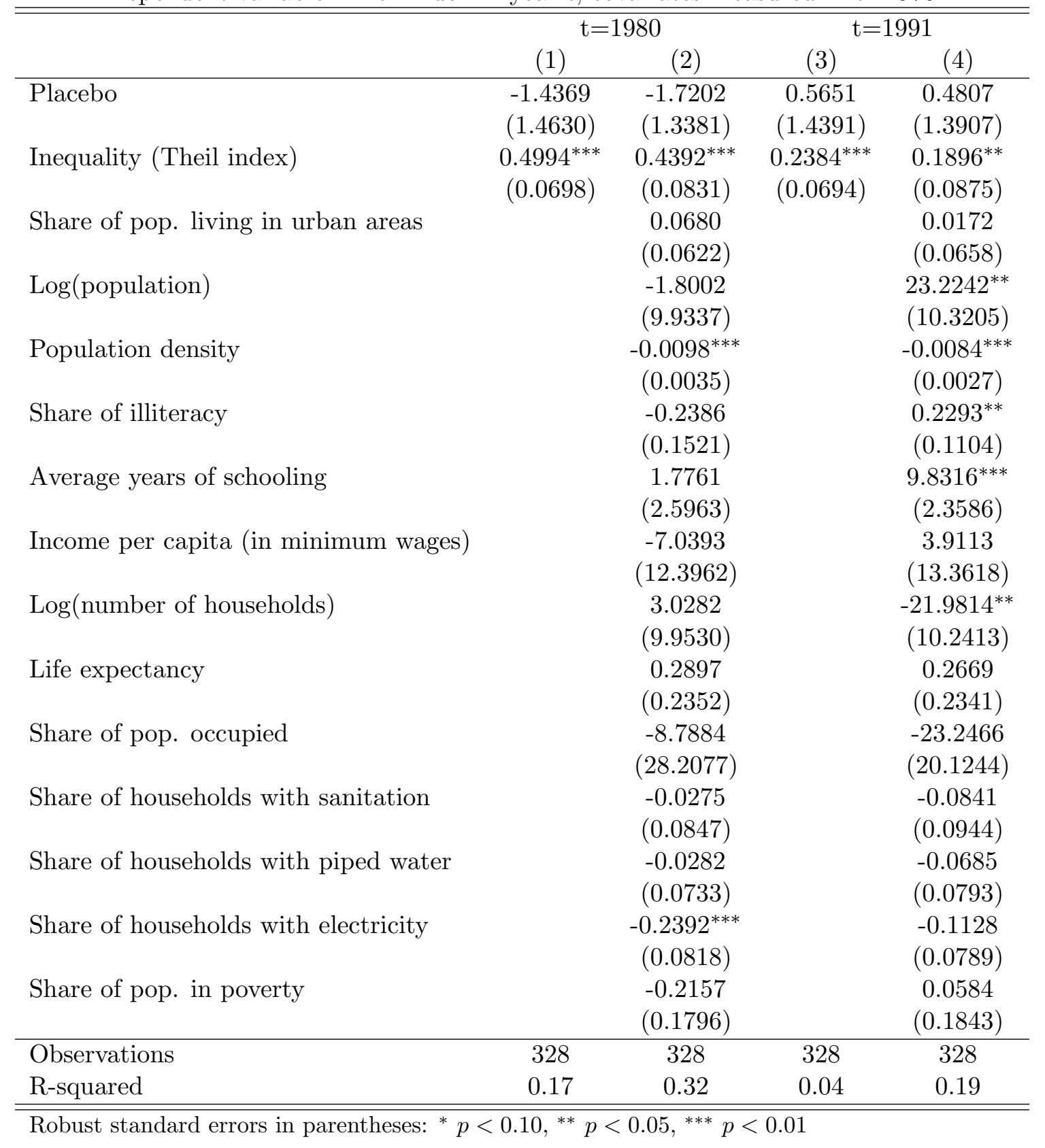


Table 9: Placebo: effect on income distribution in 1991

\begin{tabular}{|c|c|c|c|c|c|}
\hline & $\begin{array}{c}(1) \\
\text { Share of } \\
\text { income } \\
\text { earned by } \\
\text { the } 20 \% \\
\text { poorest }\end{array}$ & $\begin{array}{c}(2) \\
\text { Share of } \\
\text { income } \\
\text { earned by } \\
\text { the } 40 \% \\
\text { poorest }\end{array}$ & $\begin{array}{c}(3) \\
\text { Share of } \\
\text { income } \\
\text { earned by } \\
\text { the } 60 \% \\
\text { poorest }\end{array}$ & $\begin{array}{c}(4) \\
\text { Share of } \\
\text { income } \\
\text { earned by } \\
\text { the } 20 \% \\
\text { richest }\end{array}$ & $\begin{array}{c}(5) \\
\text { Share of } \\
\text { income } \\
\text { earned by } \\
\text { the } 10 \% \\
\text { richest }\end{array}$ \\
\hline Placebo & $\begin{array}{c}-0.0377 \\
(0.0959)\end{array}$ & $\begin{array}{c}-0.0638 \\
(0.2277)\end{array}$ & $\begin{array}{c}-0.0738 \\
(0.3991)\end{array}$ & $\begin{array}{c}0.0751 \\
(0.6089)\end{array}$ & $\begin{array}{c}-0.0040 \\
(0.7196)\end{array}$ \\
\hline Inequality (Theil index) & $\begin{array}{l}-0.0037 \\
(0.0063)\end{array}$ & $\begin{array}{l}-0.0197 \\
(0.0148)\end{array}$ & $\begin{array}{l}-0.0417 \\
(0.0258)\end{array}$ & $\begin{array}{l}0.0776^{*} \\
(0.0396)\end{array}$ & $\begin{array}{c}0.0918^{* *} \\
(0.0459)\end{array}$ \\
\hline Share of pop. living in urban areas & $\begin{array}{l}-0.0032 \\
(0.0047)\end{array}$ & $\begin{array}{l}-0.0052 \\
(0.0114)\end{array}$ & $\begin{array}{l}-0.0125 \\
(0.0200)\end{array}$ & $\begin{array}{c}0.0162 \\
(0.0306)\end{array}$ & $\begin{array}{c}0.0182 \\
(0.0352)\end{array}$ \\
\hline Log(population) & $\begin{array}{c}-2.4119^{* * *} \\
(0.8265)\end{array}$ & $\begin{array}{c}-4.5505^{* *} \\
(1.9174)\end{array}$ & $\begin{array}{c}-7.1881^{* *} \\
(3.2623)\end{array}$ & $\begin{array}{l}8.8067^{*} \\
(4.7612)\end{array}$ & $\begin{array}{c}9.0558^{*} \\
(5.3916)\end{array}$ \\
\hline Population density & $\begin{array}{c}0.0006^{* * *} \\
(0.0001)\end{array}$ & $\begin{array}{c}0.0015^{* * *} \\
(0.0004)\end{array}$ & $\begin{array}{c}0.0028^{* * *} \\
(0.0008)\end{array}$ & $\begin{array}{c}-0.0040^{* * *} \\
(0.0013)\end{array}$ & $\begin{array}{c}-0.0043^{* * *} \\
(0.0015)\end{array}$ \\
\hline Share of illiteracy & $\begin{array}{c}-0.0220^{* *} \\
(0.0092)\end{array}$ & $\begin{array}{c}-0.0496^{* *} \\
(0.0198)\end{array}$ & $\begin{array}{c}-0.0902^{* * *} \\
(0.0337)\end{array}$ & $\begin{array}{c}0.1186^{* *} \\
(0.0513)\end{array}$ & $\begin{array}{c}0.1191^{* *} \\
(0.0599)\end{array}$ \\
\hline Average years of schooling & $\begin{array}{c}-0.8197^{* * *} \\
(0.1508)\end{array}$ & $\begin{array}{c}-1.9223^{* * *} \\
(0.3686)\end{array}$ & $\begin{array}{c}-3.2204^{* * *} \\
(0.6861)\end{array}$ & $\begin{array}{c}3.9467^{* * *} \\
(1.0968)\end{array}$ & $\begin{array}{c}3.6869^{* * *} \\
(1.2741)\end{array}$ \\
\hline $\begin{array}{l}\text { Income per capita (in minimum } \\
\text { wages) }\end{array}$ & -0.2753 & -0.9571 & -2.6795 & 3.6392 & 3.4118 \\
\hline & $(1.0091)$ & $(2.2804)$ & $(4.0082)$ & $(6.2840)$ & $(7.1242)$ \\
\hline Log(number of households) & $\begin{array}{c}2.2352^{* * *} \\
(0.8256)\end{array}$ & $\begin{array}{l}4.1479^{* *} \\
(1.9095)\end{array}$ & $\begin{array}{l}6.5570^{* *} \\
(3.2447)\end{array}$ & $\begin{array}{c}-8.0269^{*} \\
(4.7380)\end{array}$ & $\begin{array}{l}-8.4462 \\
(5.3655)\end{array}$ \\
\hline Life expectancy & $\begin{array}{l}-0.0205 \\
(0.0186)\end{array}$ & $\begin{array}{l}-0.0492 \\
(0.0413)\end{array}$ & $\begin{array}{l}-0.0886 \\
(0.0698)\end{array}$ & $\begin{array}{c}0.1182 \\
(0.1050)\end{array}$ & $\begin{array}{c}0.0818 \\
(0.1223)\end{array}$ \\
\hline Share of pop. occupied & $\begin{array}{c}1.2378 \\
(1.4382)\end{array}$ & $\begin{array}{c}3.7409 \\
(3.3880)\end{array}$ & $\begin{array}{c}6.7186 \\
(5.9603)\end{array}$ & $\begin{array}{r}-12.7181 \\
(9.0014)\end{array}$ & $\begin{array}{l}-16.2033 \\
(10.1398)\end{array}$ \\
\hline Share of households with sanitation & $\begin{array}{c}0.0063 \\
(0.0064)\end{array}$ & $\begin{array}{c}0.0143 \\
(0.0148)\end{array}$ & $\begin{array}{c}0.0209 \\
(0.0262)\end{array}$ & $\begin{array}{l}-0.0235 \\
(0.0413)\end{array}$ & $\begin{array}{l}-0.0281 \\
(0.0492)\end{array}$ \\
\hline $\begin{array}{l}\text { Share of households with piped } \\
\text { water }\end{array}$ & $0.0133^{* * *}$ & 0.0192 & 0.0237 & -0.0146 & -0.0027 \\
\hline & $(0.0050)$ & $(0.0126)$ & $(0.0233)$ & $(0.0371)$ & $(0.0436)$ \\
\hline Share of households with electricity & $\begin{array}{c}0.0007 \\
(0.0056)\end{array}$ & $\begin{array}{c}0.0177 \\
(0.0130)\end{array}$ & $\begin{array}{l}0.0417^{*} \\
(0.0231)\end{array}$ & $\begin{array}{c}-0.0631^{*} \\
(0.0368)\end{array}$ & $\begin{array}{l}-0.0604 \\
(0.0438)\end{array}$ \\
\hline Share of pop. in poverty & $\begin{array}{l}-0.0041 \\
(0.0136)\end{array}$ & $\begin{array}{l}-0.0129 \\
(0.0316)\end{array}$ & $\begin{array}{l}-0.0324 \\
(0.0553)\end{array}$ & $\begin{array}{c}0.0453 \\
(0.0851)\end{array}$ & $\begin{array}{c}0.0465 \\
(0.0956)\end{array}$ \\
\hline Observations & 328 & 328 & 328 & 328 & 328 \\
\hline R-squared & 0.21 & 0.22 & 0.21 & 0.17 & 0.13 \\
\hline
\end{tabular}

Robust standard errors in parentheses: ${ }^{*} p<0.10,{ }^{* *} p<0.05,{ }^{* * *} p<0.01$ 


\subsection{Conclusions}

This chapter contributes to the political economy literature by studying the existence of capture at local levels of government, a question still underexplored in the body of empirical research, in the context of the Brazilian dictatorship. This is done by comparing measures of inequality between municipalities that had appointed mayors during the dictatorship with a set of municipalities where mayors were elected directly. The Brazilian dictatorship is an interesting context within which to study such a phenomenon for two reasons. First, it provides this unusual variation in political institutions at the local level. Second, this period was characterized by a large number of ambitious central government projects, implying a large amount of resources spent, which allows to investigate the presence of practices related to capture.

To overcome the clear issue of the selection of disenfranchised municipalities, this chapter combines a GRD design with matching techniques, relying on the hypothesis that the main source of selection is related to the geographic characteristics of the municipalities. Evidence is provided that the strategy employed results in a control group that is similar to the group of treated municipalities in a number of relevant predetermined (observable) characteristics.

The main findings are consistent with the hypothesis of elite capture at the local level, since they indicate an increase not only in income inequality in municipalities that had mayors appointed by the regime but also in the share of income earned by the richest. Nonetheless, the results are also consistent with other stories (i.e: stronger presence of military officials in municipalities that had appointed mayors, different incentives/preferences between elected and appointed mayors, non-continuous effects of geography). 


\section{MEDIA CAPTURE IN NON-DEMOCRATIC REGIMES: EVIDENCE FROM THE BRAZILIAN DICTATORSHIP}

\section{$2.1 \quad$ Introduction}

The question of how and to what extent media can affect voting behavior and political and economic outcomes has been extensively discussed in both the economics and political science literature ${ }^{22}$ An interesting related topic that has been studied in recent years is the extent to which media vehicles are prone to political capture. Theoretical evidence suggests that media capture depends on institutional characteristics and media market characteristics. $^{23}$

This chapter investigates this particular issue in the context of the Brazilian dictatorship (1964-1985). This context is interesting for two reasons. First, in non-democratic regimes, media vehicles are expected to be more prone to political capture. In fact, one theoretical result documented by Besley \& Prat (2006) and Prat \& Strömberg (2011) is that when the transaction costs between the government and media industry are lower, industry is more likely to be captured in equilibrium. Second, the period analyzed in this chapter is one characterized by low competition and large expansion of the television market. ${ }^{24} \mathrm{~A}$ second important theoretical result directly linked to this point and documented by the same authors is that media pluralism could provide protection against capture.

Capture is only an intermediate phenomenon and one that is difficult to measure directly. We are more interested in the effect of capture on key political outcomes Prat \& Strömberg (2011). Therefore, to address this issue, this chapter investigates the effects of Rede Globo (hereafter, Globo), the primary Brazilian television station, on electoral outcomes of mayoral elections during the Brazilian dictatorship, mainly on the share of votes obtained by Aliança Renovadora Nacional (hereafter, ARENA), the ruling party during the dictatorship. To identify such effects, this chapter exploits the timing of Globo's entry into different municipalities. The main empirical challenge for identifying if the presence of Globo in a municipality affects electoral outcomes is the possibility that its entry is correlated with political preferences at the municipality level. The results indicates that, conditional on a set of municipality-level controls and on municipality and year

\footnotetext{
${ }^{22}$ See Besley \& Burgess (2002), Dyck \& Zingales (2002) and Hamilton (2004).

${ }^{23}$ See Besley \& Prat (2006) and Prat \& Strömberg (2011).

${ }^{24}$ According to Straubhaar (1989), Globo had roughly $70 \%$ of the audience by the end of the $1980 \mathrm{~s}$.
} 
fixed-effects, there is no evidence of a politically driven entry of Globo.

The main effects documented in this chapter show that Globo has an average negative effect on ARENA's vote-share in the three mayoral elections between 1972 and 1982. In principle, this is not consistent with the hypothesis of media capture. Evaluating the results more deeply, however, shows that during the first years of the military dictatorship, Globo has a positive effect on ARENA's vote-share. In the latter years, however, the effect becomes negative and, on average, overlaps the positive result. These results are consistent with the theoretical result documented by Prat \& Strömberg (2011), according to which the presence of a news-related profit motive makes it more difficult for media vehicles to be captured. Anecdotal evidence discussed latter in this chapter suggests that this is the case. Straubhaar (1989) and Porto (2008) suggest that as a response to the new context of political and economic crisis, Globo assumed a critical role in the last years of the regime, ignoring censorship and incorporating problems and demands of the social reality in their shows.

In order to better understand this sudden break in Globo's effect, the content of Brazilian soap operas, known as novelas, were coded and used in the analysis presented here. The main results show that exposure to novelas with politically related content has a negative effect on ARENA's vote-share.

The literature focusing on media capture is scarce. Probably the most convincing evidence of the existence of media capture was provided by McMillan \& Zoido (2004). These authors use a data set to reconstruct a complex system of bribes created during Alberto Fujimori's presidency in Peru from 1990 to 2000. To keep democratic forces at bay, Fujimori needed to buy acquiescence from three classes: legislators, judges, and media vehicles. Therefore, their study offers a unique perspective on the process of subverting democracy. In particular, it investigates which of these three classes posed the strongest resistance to Fujimori. The study's main finding is that bribing the media is much more expensive than bribing individuals. According to the paper, Fujimori spent ten times more on bribes to television channels than bribes to politicians to secure a majority in Congress or for guaranteeing a friendly judiciary. Additional evidence on media capture was provided by Tella \& Franceschelli (2009), who analyzed each of the four major newspapers in Argentina between 1998 and 2007. The focus was on how much first-page coverage is devoted to corruption scandals and how much money each newspaper receives from government-related advertising. The authors found a strong negative correlation between 
these two variables.

A broader and more closely related literature documents the relationship between media freedom/media competition and economic and electoral outcomes. Using a panel data from India, Besley \& Burgess (2002) show that state governments are more responsive to decreases in food production and crop flood damage where newspaper circulation is higher and electoral accountability is greater. Strömberg (2004) shows a positive correlation between radio listeners and relief funds from the New Deal. In a cross-country study using data on media ownership in 97 countries, Djankov et al. (2001) documents that state ownership of the media is related to less press freedom, fewer political and economic rights, and inferior social outcomes in the areas of education and health. Gentzkow, Glaeser \& Goldin (2006) use historical data to study the long-term evolution of media independence and associate the reduction of corruption in the United States between 1870 and 1920 to changes in the American newspaper industry occurring in the same period.

This chapter also refers to the empirical literature on media bias (DellaVigna \& Kaplan (2006);Herman \& Chomsky (2010); Groseclose \& Milyo (2005) and Puglisi (2011)) and the broader literature discussing the effects of media on political outcomes (Gentzkow (2006); Gerber \& Green (2000); Gerber, Karlan \& Bergan (2006); George \& Waldfogel (2002) and Prior (2007)).

The remaining chapter sections are organized as follows. Section 2.2 discusses how mayoral elections were organized in Brazil during the dictatorship, the relationship between Globo and the dictatorship and the relevance of novelas. Section 2.3 describes the datasets on election outcomes, Globo's coverage, and novela content used in this chapter. Section 2.4 details the empirical strategy. Section 2.5 presents the main results. Section 2.6 concludes.

\subsection{Institutional Background}

\subsubsection{Elections during the Brazilian dictatorship}

The Brazilian military dictatorship began in March 1964 when President João Goulart was overthrown by a coup d'etat led by the Armed Forces. It lasted for more than 20 years and officially ended in 1985, when José Sarney, elected by indirect elections, took office as president. Besides a set of measures that characterize all dictatorships, including political 
violence, persecution of the opposition, and legislative casuistry, the Brazilian military dictatorship had a unique political system compared to other dictatorships. For example, when the head of government is in power without interruption, parties are forbidden to work, Congress is closed, and the elections are suspended. During most years of the military government, military-presidents and state governors were chosen by the National Congress and State Legislative Houses, respectively. Moreover, legislative representatives such as senators, congressmen, state legislators, and city councilors continued to be chosen by direct vote during the entire regime. In contrast, mayors were elected by direct vote during all years of the regime in most municipalities. ${ }^{25}$

The partisan system in Brazil during the period analyzed in this chapter should also be highlighted. The multi-party system created in 1946 was abolished in 1965 by Institutional Act Number 2, which created a two-party system, with ARENA (Aliança Renovadora Nacional), the ruling party, and MDB (Movimento Democrático Brasileiro) playing the role of the opposition. Until the end of the 1970s, these two political parties were the only ones officially registered and able to run for election. In 1979, however, law number 6767 extinguished both parties and created a multi-party system. ${ }^{26}$ Among other things, the law instituted in 1979 stated that political parties should have the word party - partido in Portuguese - in their names. Therefore, MDB became PMDB (Partido do Movimento Democrático Brasileiro). ARENA, in turn, was recreated by its leaders as the Partido Democrático Social (PDS). Three other parties that obtained registration to run in the 1982 elections, Partido Trabalhista Brasileiro, Partido Democrático Trabalhista and Partido dos Trabalhadores, comprised politicians whose political rights had been revoked during the early years of the dictatorship in addition to other politicians returning from exile.

Table 10 shows the elections during the military dictatorship, including four rounds of mayoral elections. The first round was not simultaneous in all states and occurred between 1965 and 1970. The other three rounds occurred in 1972, 1976, and 1982 in all states of the country simultaneously; these are the elections analyzed in this chapter.

Although the analysis focuses on mayoral elections, the general scenario of elections are es-

\footnotetext{
${ }^{25}$ State capitals, municipalities considered to be water resorts and municipalities located in national security areas had mayors appointed by the state governors. This chapter is not concerned with the reasons behind the government's determination that these municipalities would have mayors appointed. This issue only affects the external validity of this study's results.

${ }^{26}$ Available at <http://www.planalto.gov.br/ccivil_03/leis/1970-1979/L6767.htm>.
} 
sential to understand. Until 1973, the Brazilian economy underwent high rates of growth ${ }^{27}$ and as a result, ARENA fared well in both local and national elections Nicolau (2012). After 1973, with the onset of the oil crisis, economic growth slowed. Consequently, the opposition party started to grow and faced its first electoral win in the 1974 election. In response to this shifting political scenario, President Ernesto Geisel established a project of political openness that intended to be "slow, gradual and safe", in his own words (Porto (2008)). The creation of a multi-party system and the gubernatorial elections in 1982 listed in Table 10 can be understood as reflecting this process.

Table 10: Direct elections during the Brazilian military dictatorship

\begin{tabular}{|c|c|c|c|c|}
\hline & $\begin{array}{c}\text { Federal } \\
\text { Deputies and } \\
\text { Senators }\end{array}$ & Governor & State Deputy & $\begin{array}{l}\text { Mayors and } \\
\text { City Council }\end{array}$ \\
\hline 1965 & & October 3rd & & \\
\hline 1966 & November 15 th & & November 15 th & November 15 th \\
\hline 1968 & & & & November 15 th \\
\hline 1969 & & & & November 30 th \\
\hline 1970 & November 15 th & & November 15 th & November 15 th \\
\hline 1972 & & & & November 15 th \\
\hline 1974 & November 15 th & & November 15 th & \\
\hline 1976 & & & & $\begin{array}{l}\text { November } 15 \text { th } \\
\text { / December } \\
20 \text { th }\end{array}$ \\
\hline 1978 & November 15 th & & November 15 th & \\
\hline 1982 & November 15 th & November 15 th & November 15 th & November 15 th \\
\hline
\end{tabular}

Source: http://www.tse.jus.br/eleicoes/cronologia-das-eleicoes

${ }^{27}$ This period, known as the "Brazilian miracle", was discussed in the previous chapter. 


\subsubsection{Rede Globo and the military regime}

It is not possible to state that Globo's establishment in 1965 marks the beginning of the television history in Brazil, but it does mark the beginning of the history of mass media there. The story of television in Brazil began in 1950 with TV Tupi, but only after the middle of the $1960 \mathrm{~s}$, a period coinciding with the foundation of Globo, ${ }^{28}$ did television become a popular media instrument in Brazil. This is due to two main factors. The first factor involved Globo's strategy of aiming at the more general public by broadcasting popular shows (Almeida (1971)). Second, credit policies were implemented during the military regime, which were meant to provide incentives to buy durable goods such as televisions, the sales of which greatly increased during this period. ${ }^{29}$

Both Globo's geographical expansion and their audience increased rapidly over the decades. In 1970, only five years after its official establishment, around 200 municipalities were covered by Rede Globo. In 1980, this figure had increased to more than 2000 municipalities, more than half of all municipalities nationwide at that time. In addition, according to Straubhaar (1989), Globo had roughly $70 \%$ of the Brazilian audience by the end of the 1980s.

For the purpose of this chapter's identification strategy, understanding how the expansion of Rede Globo occurred is essential. Despite the conclusions of some studies that the concessions of televisions networks followed clientelistic, political and ideological criteria (Lima (2001)), results presented latter in this chapter show that this argument is not supported by the data. In fact, according to results documented here, the decision of Globo to enter a municipality can be explained more by measures of income and by the share of households with a television in the municipality.

Nonetheless, the role played by Globo during the military government cannot be ignored. In fact, this topic has been studied by many authors from many disciplines. ${ }^{30}$ The general understanding is that Globo was a main supporter of the coup d'etat and that it was used by the regime as a key vehicle for cultural, political, and economic integration of the

\footnotetext{
${ }^{28}$ Rede Globo the television company was founded in 1965. The company's newspaper $O$ Globo existed since 1925 .

${ }^{29}$ The sales of black-and-white televisions in Brazil grew 241\% between 1867 and 1979, whereas those of color televisions grew 1479\% between 1972 and 1979 (Mattos (1982)).

${ }^{30}$ For a detailed discussion on the relationship between television and the dictatorship regime, see Straubhaar (1989).
} 
country (Miguel (2001)). In an editorial published in September 2013, Rede Globo itself came to recognize many years after the end of the military regime the support that its newspaper, O Globo, provided for the 1964 coup:

Rede Globo, in fact, at the time, supported the military intervention. (...) Back then, the military intervention was justified for fear of another coup by President João Goulart, with broad support from unions and some segments the Armed Forces. (...) Through the light of the history, however, there is no reason not to recognize today, explicitly, that the support was a mistake as were other editorial decisions of the period. ${ }^{31}$

The role played by Globo during the dictatorship, however, changed over time. If in the beginning of the regime, Globo clearly supported the central government, the scenario changed in later years. According to Straubhaar (1989), in the last years of the regime, Globo assumed a critical role by ignoring censorship warnings and airing live coverage of demonstrations during days and evenings as well as in formal newscasts. In April 1984, for example, Globo covered a major rally for direct elections in Rio de Janeiro for one hour spread across the day, including during the prime-time novelas and newscasts. Porto (2008) suggests that the relationship between Globo and the dictatorship changed, with Globo incorporating problems and social demands in their shows, as a response to the new context of political and economic crisis.

\subsubsection{The importance of Globo Novelas}

In order to understand the results presented here, the importance of Globo Novelas should be emphasized. Faria \& Potter (1999) stress the role played by television for the function and presentation of contemporary Brazilian society and in the process of diffusing and institutionalizing new behavioral patterns nationwide. In fact, this has been documented empirically by Ferrara, Chong \& Duryea (2012) and by Chong \& Ferrara (2009) studying the effects of novelas on fertility and divorce rates, respectively.

One crucial reason for television's influence in Brazil is the strength of the country's oral tradition. This is especially relevant in the period discussed in this paper, in which the

\footnotetext{
${ }^{31}$ Source: <http://oglobo.globo.com/brasil/apoio-editorial-ao-golpe-de-64-foi-um-erro-9771604>
} 
illiteracy rate is very elevated. ${ }^{32}$ Another factor contributing to novelas' influence on Brazilian life is that the context and issues they commonly address always relate to the daily lives of the Brazilian population. Moreover, novelas use colloquial language that renders the shows accessible to more viewers and thus results in their enormous success (Ferrara, Chong \& Duryea (2012)).

The story of Globo's novelas during the dictatorship can be understood in two distinguished moments that coincided with the process of political opening and the shift in Globo's support to the military dictatorship. The first phase between 1964 and 1973 was strongly shaped by the military dictatorship. The novelas had to constrain their criticisms to political and economic issues, maintain conventional social behaviors and morals, and most importantly, they had to create and reinforce a positive image of the regime (Straubhaar (1988)). After 1973, however, as previously mentioned, the relationship between Globo and the dictatorship changed, and this had a reflect on the content of the novelas, with problems and demands of social reality being incorporated into them.

\subsection{Data}

\subsubsection{Municipal elections}

The main dependent variables used in this chapter were constructed from historical files of the Federal Electoral Authority, the Tribunal Regional Eleitoral (TSE). They contain outcomes of the 1972, 1976, and 1982 mayoral elections. As previously mentioned, not all municipalities had mayoral elections during the military dictatorship. This research is not concerned with the issue of selection in the choice of these municipalities, as this only affects the external validity of the results in the sense that they cannot be extrapolated to the entire country. In other words, the results are valid only for the subset of municipalities hosting mayoral elections between 1972 and 1982. These were typically smaller and more rural than the municipalities with appointed mayors, especially state capitals.

The variables obtained from the TSE files were ARENA's vote-share, voter turnout, the share of blanks and null votes, and MDB's vote-share. This analysis is focused on the first three variables, especially the vote-share of the ruling party, ARENA. Figure 6 shows the

\footnotetext{
${ }^{32}$ In 1970 , the adult illiteracy rate was $32.97 \%$. Despite programs of the central government to reduce adult illiteracy during the years of the regime, this rate had decreased to only $19.40 \%$ in 1990 .
} 


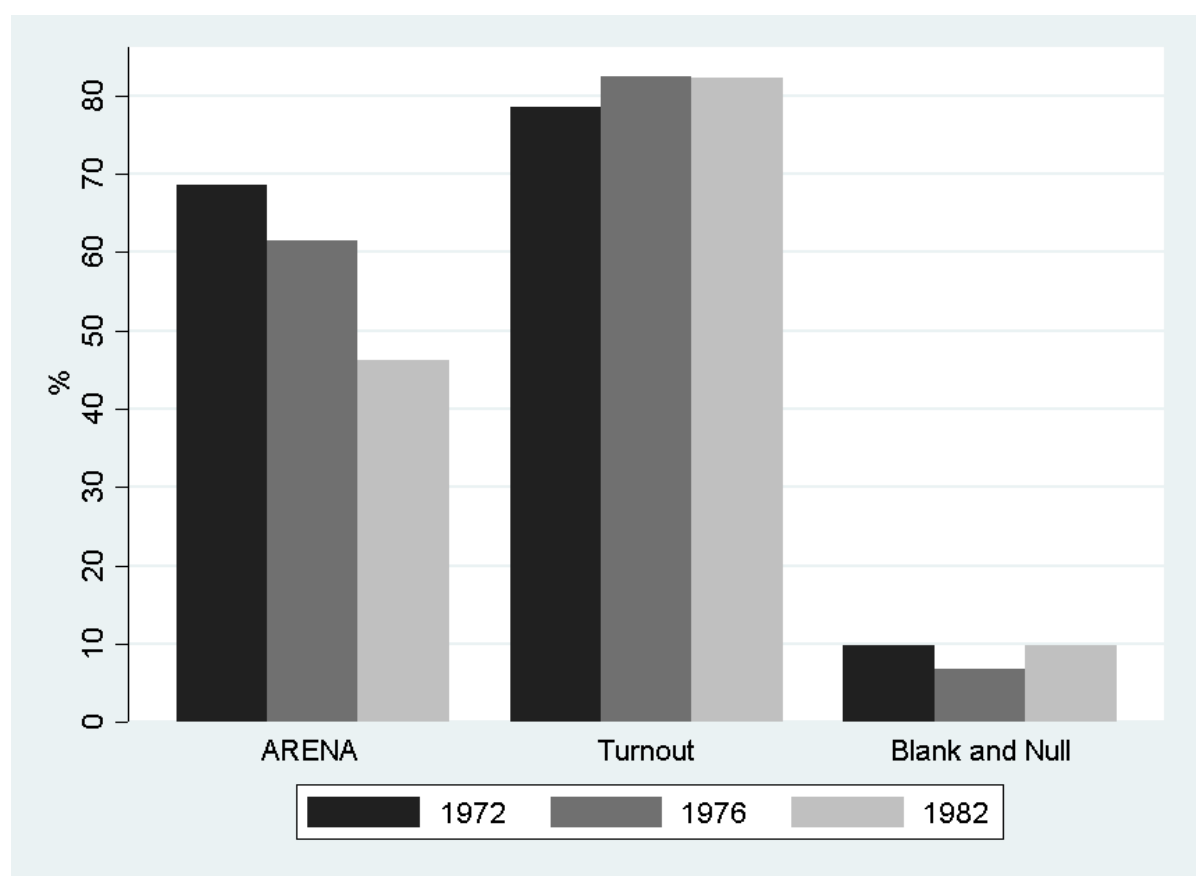

Figure 6: Electoral outcomes in 1972, 1976 and 1982 mayoral elections

average of the main variables of interest over time.

Voter turnout increases over time, from around $78.5 \%$ in 1972 to more than $82 \%$ in 1982 . In fact, this is a period with huge increases in both voter turnout and voter registration. Nicolau (2012) documents that between 1966 and 1982, the proportion of citizens registered to vote increased from $39 \%$ to $73 \%$. According to him, two factors might have played a significant role on this phenomenon. First, the Electoral Code approved in 1965 predicted a series of sanctions for voters who do not vote. Before approval of this code, the voter who failed to vote had only to pay a fine, but after its approval, voters could experience a series of difficulties such when they applied for a job in a state-managed company, had a passport issued, or obtained a loan from public banks, to name a few. ${ }^{33}$ Second, with the increase of children in schools in the 1940s and 1950s, the number of young literate people increased significantly after 1960: the share of illiterate adults decreased from $40 \%$ in 1970 to $26 \%$ in 1980, according to demographic censuses from that period. Besides these demographic and educational changes, Limongi, Cheidub \& Figueiredo (2015) also stress the role of urbanization in decreasing the cost of registering and the effort invested by MDB in convincing voters to participate in local elections.

ARENA's vote-share decreases over time. Between 1972 and 1976, the share of votes

\footnotetext{
${ }^{33}$ Available at <http://www.tse.jus.br/legislacao/codigo-eleitoral/codigo-eleitoral-1/sumarios/ sumario-codigo-eleitoral-lei-nb0-4.737-de-15-de-julho-de-1965>
} 
received by ARENA as a proportion of the total valid votes fell from $68.53 \%$ to $61.53 \%$. This result can be understood as a response to the changes in economic and social conditions discussed in the previous sections. In fact, recognizing this change in the political situation, a law was instituted in July 1976, known as Lei Falcão. It determined that in electoral propaganda, both on radio and television, parties were only allowed to mention the name of their own political party, their curriculum, and their registration number in the Electoral Court. The general understanding is that the law was created as a response to the 1974 election results, in which the MDB had 16 senators elected, while ARENA had only six. Therefore, the law avoided political debate and stopped the MDB's growth. ${ }^{34}$ The decrease between 1976 and 1982 can be understood as a continuation of this natural process of economic and social changes as well as a result of the change in the composition of political parties after $1979 .{ }^{35}$

Finally, the share of blank and null votes does not present a clear pattern during this period. Between 1972 and 1976, that amount decreases from $9.75 \%$ to $6.77 \%$, returning to $9.74 \%$ in the 1982 elections.

\subsubsection{Globo's coverage}

The second data source was partially provided by Rede Globo and partially obtained from Anatel's website (Agencia Nacional de Telecomunicações) and it contains information on the location, year of installation, and radial reach in kilometers of each broadcasting and retransmitting station. This allows to know which municipalities were reached by the signal of any particular antenna and in which year they first started receiving the signal. It also allows one to construct a variable Globo coverage $i t$ equal to 1 if municipality $i$ is within the signal radius of a Globo broadcasting or retransmitting station in municipal elections in year $t$, and 0 otherwise. As the 1972, 1976, and 1982 municipal elections were held on November 15th of each year, its required that the municipality was reached by Globo before November of that year. As a robustness check, the main regressions are estimated requiring coverage six months and one year before the elections. The results are reported in Tables 30 to 33 in appendix B.

\footnotetext{
${ }^{34}<$ http://www12.senado.gov.br/noticias/materias/2006/07/03/lei-falcao-faz-30-anos>

${ }^{35}$ As discussed in the last sections, ARENA was formally extinguished in 1979 and recreated by its leaders as the Partido Democrático Social (PDS). Therefore, for the 1982 elections, the PDS' vote-share is considered.
} 


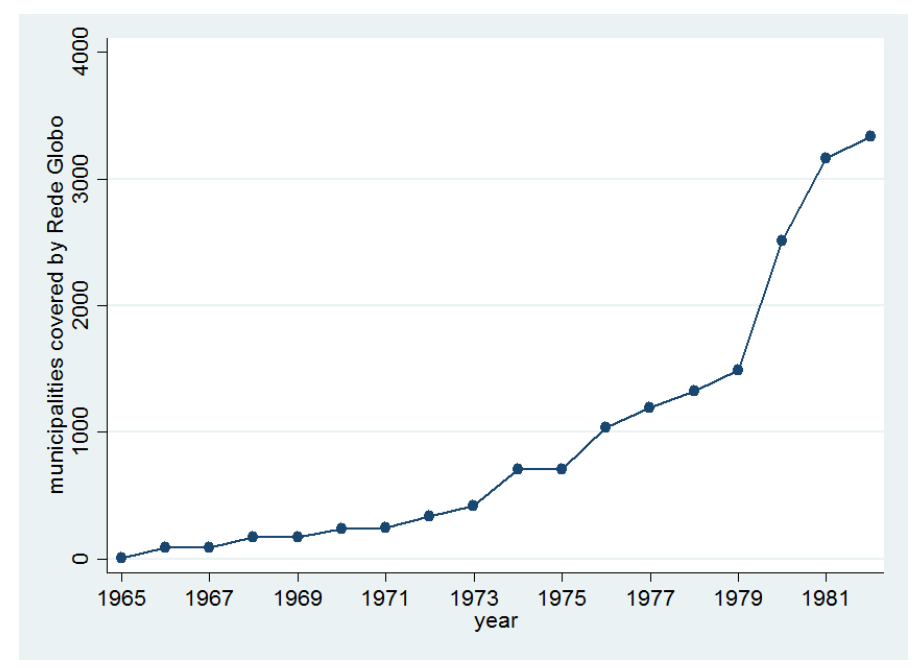

Figure 7: Increase of Rede Globo coverage over time

Figure 7 shows the increase over time in the number of municipalities reached by the Globo signal. In 1970, around 200 municipalities were receiving the Globo signal. By the end of 1976 and 1982, this number increased to over 1000 and 3000 municipalities, respectively.

Figure 8 shows the geographic expansion of the network between 1965 and 1982. Darker colors correspond to an earlier exposure to the signal. This figure suggests that the entry of Globo into different areas was not random, but it had a clear pattern: Globo reached the most developed parts of Brazil first, specifically in the southeast and the capitals of the northeast, which is potentially a concern for identifying the causal relation between Globo and electoral outcomes. Results of exercises presented in Section 2.5.1, however, show that after controlling for time-varying controls and municipality and year fixedeffects, no evidence of selection on unobservable characteristics correlated with electoral outcomes is found, especially with ARENA's vote-share, which represents the primary outcome of interest in this chapter. 


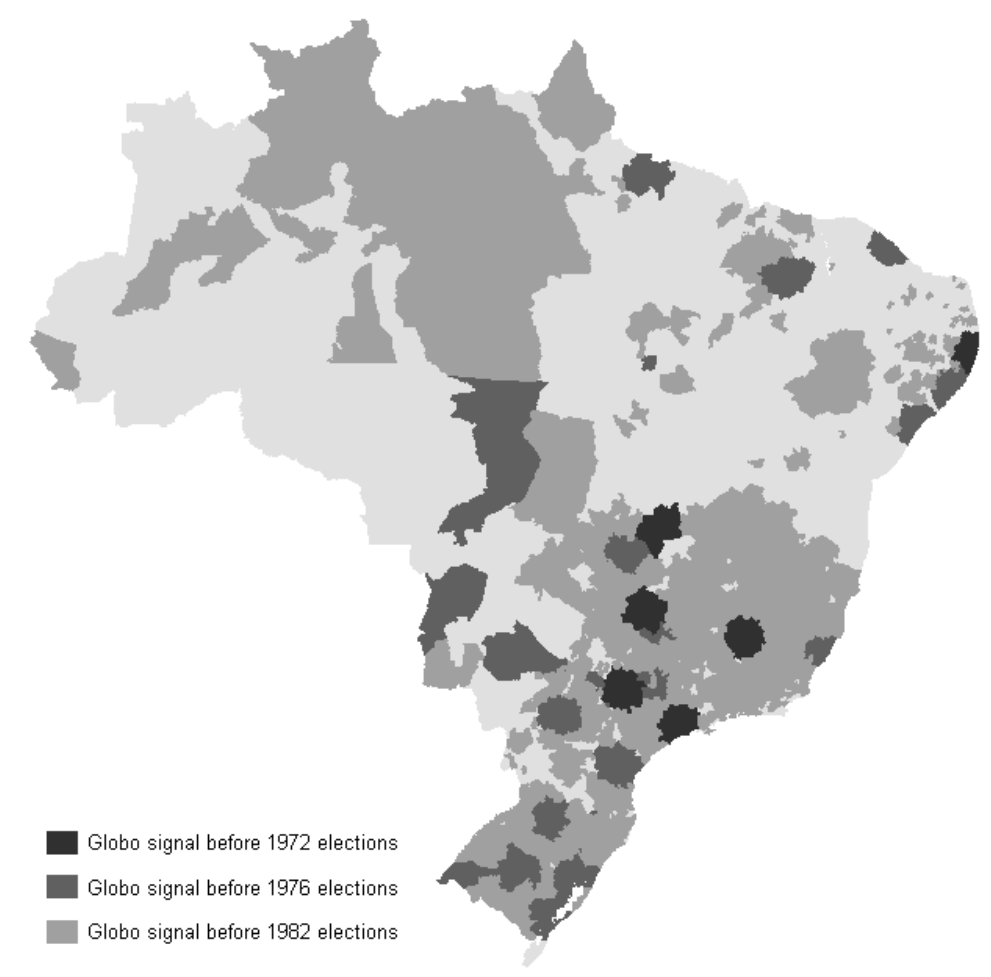

Figure 8: Geographical distribution of Rede Globo's coverage over time

\subsubsection{Novela content analysis}

To help understand the effect of Globo on electoral outcomes, the content of each novela broadcast by Rede Globo since the start of its operations and 1982 were coded. Based on a summary of plots obtained in the official website http://memoriaglobo.globo.com/, a dataset with a series of variables describing the content of each novela was constructed. Table 11 presents the description of each variable created from the summaries.

Table 12 presents the main results of the coding and summarizes the main characteristics of novelas aired in this period. Column (1) presents the share of novelas with a specific content aired between the beginning of Globo's operation and November 1972, the month of the first mayoral election studied here. Column (2) shows the same figures but for novelas aired between November 1972 and November 1976. Finally, column (3) presents novelas aired between November 1976 and November 1982.

Consistent with what was discussed in previous sections, Table 12 shows that the content of novelas change over time. The change in the contents, however, was not abrupt. As observed by Straubhaar (1989), this process was slowed by both official and internal censorship. The figures in Table 12 illustrate this fact. Comparing column (1) to column (2), 
Table 11: Novela content coding

\begin{tabular}{|c|c|c|}
\hline Variable & Description & Coding options \\
\hline Political Issues & Discussion of political issues & $\begin{array}{l}0=\text { does not discuss } \\
1=\text { discuss in the main plot } \\
2=\text { discuss in one of the secondary plots }\end{array}$ \\
\hline Nature of Political Issue & Nature of the political issues discussed & $\begin{array}{l}0=\text { does not discuss } \\
1=\text { Corruption } \\
2=\text { Elections } \\
3=\text { Allocation of public resources } \\
4=\text { Demand for democracy } \\
5=\text { Other Not clear in the summary }\end{array}$ \\
\hline Political Character & $\begin{array}{l}\text { Presence of a character that makes opposition } \\
\text { to the ruling party/to a powerful group }\end{array}$ & $\begin{array}{l}0=\text { does exist a character that makes opposi- } \\
\text { tion to the ruling party/to a powerful group } \\
1=\text { one of the main characters makes opposi- } \\
\text { tion to the ruling party/to a powerful group } \\
2=\text { one of the secondary characters makes } \\
\text { opposition to the ruling party/to a powerful } \\
\text { group }\end{array}$ \\
\hline Historical & $\begin{array}{l}\text { Main plot of the Soap Opera is not contempo- } \\
\text { raneous }\end{array}$ & $\begin{array}{l}0=\text { plot is contemporaneous } \\
1=\text { plot is not contemporaneous }\end{array}$ \\
\hline Rural & One of the Soap Opera's plots is rural & $\begin{array}{l}0=\text { No rural plot } \\
1=\text { Main plot or one of the secondary plots is } \\
\text { rural }\end{array}$ \\
\hline Periphery & $\begin{array}{l}\text { Discussion of daily issues of peripheral areas in } \\
\text { Brazilian cities }\end{array}$ & $\begin{array}{l}0=\text { does not discuss } \\
1=\text { discuss in the main plot } \\
2=\text { discuss in one of the secondary plots }\end{array}$ \\
\hline Prejudice & Discussion of social/racial prejudice & $\begin{array}{l}0=\text { does not discuss } \\
1=\text { discuss either in the main plot or in one } \\
\text { of the secondary plots } \\
1=\text { discuss either in the main plot or in one } \\
\text { of the secondary plots }\end{array}$ \\
\hline Slavery & Discussion of slavery & $\begin{array}{l}0=\text { does not discuss } \\
1=\text { discuss either in the main plot or in one } \\
\text { of the secondary plots }\end{array}$ \\
\hline
\end{tabular}


one can see an increase in the number of novelas discussing prejudice and periphery issues. The proportion of novelas discussing political issues, on the other hand, significantly increasing from column (1) to column (2), only reaches its highest value in 1982.

Table 12: Novela content analysis: Share of novelas aired

\begin{tabular}{lccc}
\hline \hline & $(1)$ & $(2)$ & $(3)$ \\
Plot & 1965 to 1972 & 1972 to 1976 & 1976 to 1982 \\
\hline Political Issues & 10.00 & 15.63 & 20.45 \\
Political Issues (main plot) & 5.00 & 12.50 & 18.18 \\
Political Issues (secondary plot) & 5.00 & 3.13 & 2.27 \\
Political Character (main) & 2.50 & 9.38 & 13.64 \\
Political Character (secondary) & 7.50 & 3.13 & 4.55 \\
Corruption & 2.50 & 9.38 & 2.27 \\
Elections & 2.50 & 9.38 & 6.82 \\
Public Resources & - & 6.25 & - \\
Democracy & - & 9.38 & 6.82 \\
Other political issues & 7.50 & 12.50 & 15.91 \\
Historical & 32.50 & 21.88 & 31.82 \\
Rural & 20.00 & 50.00 & 45.45 \\
Periphery & 15.00 & 31.25 & 13.64 \\
Prejudice & 20.00 & 37.50 & 50.00 \\
Slavery & 10.00 & 18.75 & 9.09 \\
Number of Soap Operas & 40 & 32 & 44 \\
\hline \hline
\end{tabular}

\subsection{Empirical Strategy}

\subsubsection{Identification}

The main empirical challenge for identifying if the presence of Globo in a municipality has a significant effect on electoral outcomes is endogeneity in the timing of Globo's entry. The key identification assumption underlying the approach used here is that Globo's entry in a market, although not random, was uncorrelated with pre-existing differences in electoral characteristics across municipalities, after controlling for time-varying controls, and year and municipalities invariant characteristics. To assess the plausibility of this assumption, a series of tests were conducted.

First, previous electoral outcomes (i.e. ARENA's vote-share, voter turnout, and the share of blank and null votes) are used as proxy of electoral characteristics. The probability of Globo's entry in a municipality is estimated as a function of these variables: 


$$
\text { Globo }_{i, t}=\mathbf{X}_{\mathbf{i t}} \beta+\gamma \cdot \text { electoral outcome } i, t-1+\mu_{i}+\lambda_{t}+\varepsilon_{i t}
$$

Where Globo $_{i, t}$ equals 1 if the municipality $i$ is covered by Globo in year $t$ and zero otherwise; electoral outcome $e_{i, t-1}$ is the electoral outcome in municipality $i$ in elections happened in $t-1 ; \mathbf{X}_{\mathbf{i t}}$ is a set of time-varying controls at the municipality level; $\mu_{i}$ and $\lambda_{t}$ are municipality and year fixed-effects respectively. Because data is available only from 1972 onwards and this strategy uses lagged electoral outcomes, only information about Globo's entry between the end of 1972 and 1982 is used to estimate this equation. If the assumption that Globo's entry in a market was uncorrelated with pre-existing differences in electoral characteristics across municipalities after controlling for time-varying controls and for municipality and year fixed--effects were to hold, one should expect to obtain a coefficient $\gamma$ statistically zero.

Another possibility is that although it is not (partially) correlated with pre-existing differences in electoral characteristics, Globo's entry in a municipality is partially correlated with pre-existing differences in trends in electoral characteristics. In order to test this hypothesis, an equation similar to equation 2.1 is estimated, but using the change in electoral outcomes between $t-2$ and $t-1$ :

$$
\text { Globo }_{i, t}=\mathbf{X}_{\mathbf{i t}} \beta+\gamma \cdot \Delta \text { electoral outcome } e_{i, t-1}+\mu_{i}+\varepsilon_{i t}
$$

Because in this case it is necessary to use two lagged electoral outcomes and electoral data is available only for three periods, the regression is run in a cross-section using data of Globo's entry between the end of 1976 and 1982. Year-fixed effects, therefore, cannot be used in this specification.

Finally, a placebo exercise is conducted based on the timing of Globo's entry. These regressions are analogous to those presented in the next section to access the effect of Globo on electoral outcomes. However, instead of only looking at the effects of Globo's past entry on current electoral outcomes, the effects of future entry are also evaluated.

$$
y_{i, t}=\mathbf{X}_{\mathbf{i t}} \beta+\gamma_{1} \cdot \text { Globo }_{i t}+\gamma_{2} \cdot \text { Globo }_{i, t+1}+\mu_{i}+\lambda_{t}+\varepsilon_{i t}
$$


The regressor of interest in this exercise is Globo's coverage in $t+1$, that is, a dummy equal to 1 if the municipality $i$ is reached by the Globo signal in year $t+1$. Because every municipality receiving the signal in $t$ maintains its coverage status in $t+1$, the coefficient on this variable captures the effect of future entry for areas not covered by the signal in $t$. The hypothesis for this placebo experiment is that electoral outcomes in places not receiving the Globo signal should not be affected by the possible future availability of the signal, that is, the coefficient $\gamma_{2}$ should not be statistically different from zero.

\subsubsection{Effect on electoral outcomes}

This chapter tests the hypothesis of media capture during the Brazilian dictatorship by testing the effect of Globo, the main television broadcaster, on electoral outcomes. This is done by estimating the effect of Globo in a given year as a function of time-varying, municipality-level controls and Globo's presence through the following model:

$$
y_{i, t}=\mathbf{X}_{\mathbf{i t}} \beta+\gamma \cdot \text { Globo }_{i t}+\mu_{i}+\lambda_{t}+\varepsilon_{i t}
$$

Where $y_{i t}$ is an electoral outcome (ARENA's vote-share, voter turnout, or the share of null and blank votes) in municipality $i$ and elections in year $t$; Globo $o_{i t}$ is a dummy equal to one if municipality was reached by Globo before elections happened in $t ; \mathbf{X}_{\mathbf{i t}}$ is a set of time-varying controls at the municipality level; $\mu_{i}$ and $\lambda_{t}$ are municipality and year fixedeffects. The addition of municipality fixed-effects allows us to control for time-invariant unobserved characteristics that affect electoral outcomes and may also be correlated with the timing of Globo's entry. The year fixed-effects instead capture particular trends in electoral outcomes that are common to all municipalities. The identifying assumption is that conditional on the vector $\mathbf{X}_{\mathbf{i t}}$ of time-varying controls and on municipality and time fixed-effects, the year of Globo's entry is orthogonal to the error term. The plausibility of this assumption was discussed in the previous section and is tested in Section 2.5.1.

The presence of heterogeneous effects of Globo according to socioeconomic characteristics at the municipality level is also tested. Namely, it is tested if the effect of Globo on electoral outcomes is stronger (weaker) in municipalities with different levels of average years of schooling and with different proportions of households with televisions. The following interacted specification is estimated: 


$$
y_{i, t}=\mathbf{X}_{\mathbf{i t}} \beta+\gamma G_{i t}+\delta\left(G_{i t} * x_{i t}\right)+\mu_{i}+\lambda_{t}+\varepsilon_{i t}
$$

where $x_{i t}$ is, alternatively, average years of schooling and share of households with television. Since it was argued that the one crucial reason for television's influence in Brazil is the strength of the country's oral tradition and that this is especially relevant in the period studied when the illiteracy rate is very elevated, the effect of Globo on electoral outcomes should be less accentuated in municipalities with higher average years of schooling. Alternatively, the effect should be more accentuated in municipalities with more households with televisions.

In order to better understand the main specifications, equations 2.4 and 2.5 are also estimated interacting the presence of Globo with year dummies to test for heterogeneous effects of Globo in each election.

Finally, to help understanding results of the estimates of previous equations, whether exposure to different contents leads to different electoral outcomes is also tested. For this purpose, the information coded about the novelas aired between 1965 and 1982 is used. The following equation is then estimated:

$y_{i, t}=\mathbf{X}_{\mathbf{i t}} \beta+\gamma \cdot$ Globo $_{i t}+\delta \cdot\left(\right.$ Globo $_{i t} \cdot$ Novela Content $\left._{t, i}\right)+\alpha \cdot$ Time $_{\text {Globo }}, t+\mu_{i}+\lambda_{t}+\varepsilon_{i t}$

where Novela Content $_{i t}$ is defined as the share of time between the elections in $t$ and the elections in $t-1$ that the municipality $i$ was exposed to an specific content. ${ }^{36}$ This measure considers not only the novela's time of beginning and end, but also when the municipality started receiving Globo's signal. Because all the variation in novela content comes from the time dimension, considering when the municipality was reached by Globo introduces some cross sectional variation and reduces the noise in the estimates.

This measure of Novela Content also might capture changes in the intensive margin

\footnotetext{
${ }^{36}$ The share of time exposed to an specific content is calculated considering the number of novelas aired at the same time. For instance, if in a given year three different novelas were aired simultaneously and only one discuss prejudice, then the share of time exposed to this particular content will be $1 / 3$ even though this novela was aired during the entire year.
} 
associated with Globo. In other words, if the effect of being exposed to Globo is increasing over time, then this measure of Novela Content should also capture this effect. In order to avoid this, the variable Time Globo $i t$, the number of days between elections in $t-1$ and elections in $t$ the municipality $i$ is exposed to Globo, is included in the regression.

Note that when estimating the effect of exposure on different contents, the only variation comes from the time dimension, as no cross-sectional variation is seen in the exposure to novelas. One might be concerned that the potential effects of novela contents on electoral outcomes might stem from co-movements of average electoral outcomes and contents of the novelas. In other words, as a reflection of changes in society, ARENA's vote-share decreases over time, whereas the share of novelas discussing political issues increases and this could drive the findings latter reported in this chapter. In fact, according to section 2.3, this is what happens during this period. Luckily, this is not a concern for identifying heterogeneous effects by different contents as year fixed-effects should absorb these common changes affecting both electoral outcomes and novela contents over time. The identification of parameters in equation 2.6, therefore, comes from the combination of: i) exogeneity of the year of Globo's entry conditional on the vector $\mathbf{X}_{\mathbf{i t}}$ of time-varying controls and on municipality and year fixed-effects; and ii) use of year fixed-effects to control for common trends on electoral outcomes across all municipalities that in the absence of year fixed-effects, could be absorbed by measures of television content.

\subsection{Results}

This section takes advantage of variation in the timing of Globo's entry into different municipalities to formally test the hypothesis of media capture by estimating the effect of Globo on electoral outcomes in the mayoral elections between 1972 and 1982. First, however, the results supporting the identification strategy are presented.

\subsubsection{Identification}

The key identification assumption behind the approach used in this chapter is that Globo's entry into a market was uncorrelated with pre-existing differences in political characteristics across municipalities, after controlling for time varying controls and time invariant municipality characteristics. This section reports the results of regressions explained in 
section 2.4.1 to provide evidence that the assumption is plausible.

Table 13 presents results of the estimates of equation 2.1 using ARENA's vote-share as the electoral outcome. The dependent variable is a dummy that takes the value 1 if the municipality was covered by Globo in year $t$. As explained in Section 2.4.1, because this specification uses lagged variables, only information between the end of 1972 and 1982 is used. Column (1) shows results of the baseline specification including only year fixedeffects without time--varying municipality level controls and municipality fixed-effects. Results show that Globo is more likely to enter municipalities that had lower ARENA vote-share in the previous election. An increase in ARENA's vote-share of 10 percentage points is associated with a decrease in the probability of Globo's entry of $2.9 \%$. Column (2) presents results with the inclusion of time-varying controls. As expected, the magnitude of the coefficient associated with ARENA's vote-share in elections in $t-1$ decreases, indicating that part of the effect was due to some previously omitted variables correlated with both political preferences (e.g., ARENA's vote-share in $t-1$ ) and with Globo's entry. The effect, however, is still significant. Column (3) presents results including also municipality fixed-effects, controlling for all fixed characteristics at the municipality level that may affect both Globo's entry and ARENA's vote-share. As a result, the effect of ARENA's vote-share on Globo's entry becomes statistically insignificant, indicating that the key identification assumption holds.

Columns (4) and (5) provide additional evidence that Globo's entry is (partially) uncorrelated with ARENA's vote-share in previous elections by showing results of the estimates of equation 2.2. This specification tests if Globo's entry into a municipality is partially correlated with pre-existing differences in trends in electoral characteristics, using the change in ARENA's vote-share between the elections in year $t-2$ and $t-1$. Again, the results without the inclusion of municipality-level controls ${ }^{37}$ shows that Globo's entry is negatively associated with ARENA's performance in previous elections. In particular, an increase in ARENA's vote-share of 10 percentage points between elections in 1972 and 1976 is associated with a 1.9\% decrease in the probability of Globo's entry. When municipality level-controls are included, however, the coefficient becomes non-significant, indicating that the key identification assumption holds.

Table 14 presents the results of similar exercises, but the main dependent variables are

\footnotetext{
${ }^{37}$ In this specification, municipality fixed-effects cannot be included as only one time period of data is available
} 
Table 13: Possible selection in Globo coverage (ARENA vote-share)

Dependent variable $=1$ if Globo coverage in year $t, t=1976,1982$

\begin{tabular}{|c|c|c|c|c|c|}
\hline & $(1)$ & $(2)$ & $(3)$ & $(4)$ & $(5)$ \\
\hline ARENA vote-share t-1 & $\begin{array}{c}-0.0029^{* * *} \\
(0.0003)\end{array}$ & $\begin{array}{c}-0.0007^{* * *} \\
(0.0003)\end{array}$ & $\begin{array}{l}-0.0001 \\
(0.0005)\end{array}$ & & \\
\hline$\Delta$ ARENA vote-sharet-2,t-1 & & & & $\begin{array}{c}-0.0019^{* * *} \\
(0.0004)\end{array}$ & $\begin{array}{l}-0.0005 \\
(0.0003)\end{array}$ \\
\hline $\log$ (population) & & $\begin{array}{c}-0.0418^{* * *} \\
(0.0066)\end{array}$ & $\begin{array}{c}-0.2728^{* * *} \\
(0.0429)\end{array}$ & & $\begin{array}{c}-0.0491^{* * *} \\
(0.0078)\end{array}$ \\
\hline Share of pop living in urban areas & & $\begin{array}{c}0.0001 \\
(0.0004)\end{array}$ & $\begin{array}{l}-0.0008 \\
(0.0013)\end{array}$ & & $\begin{array}{l}-0.0008 \\
(0.0005)\end{array}$ \\
\hline Income per capita (in min wages) & & $\begin{array}{l}-0.0163 \\
(0.0247)\end{array}$ & $\begin{array}{c}0.0701 \\
(0.0555)\end{array}$ & & $\begin{array}{c}-0.0676^{* *} \\
(0.0299)\end{array}$ \\
\hline Average years of schooling & & $\begin{array}{c}0.0669^{* * *} \\
(0.0173)\end{array}$ & $\begin{array}{l}0.0696^{*} \\
(0.0418)\end{array}$ & & $\begin{array}{c}0.1261^{* * *} \\
(0.0214)\end{array}$ \\
\hline Life expectancy & & $\begin{array}{c}0.0041 \\
(0.0028)\end{array}$ & $\begin{array}{c}0.0818^{* * *} \\
(0.0086)\end{array}$ & & $\begin{array}{c}-0.0232^{* * *} \\
(0.0041)\end{array}$ \\
\hline Infant mortality (per 1000) & & $\begin{array}{l}-0.0003 \\
(0.0003)\end{array}$ & $\begin{array}{c}0.0110^{* * * *} \\
(0.0011)\end{array}$ & & $\begin{array}{c}-0.0039^{* * *} \\
(0.0004)\end{array}$ \\
\hline Share of illiterate over 15 y.o. & & $\begin{array}{l}-0.0007 \\
(0.0008)\end{array}$ & $\begin{array}{l}-0.0010 \\
(0.0018)\end{array}$ & & $\begin{array}{l}0.0021^{*} \\
(0.0012)\end{array}$ \\
\hline Share of employed people & & $\begin{array}{c}0.0023^{*} \\
(0.0012)\end{array}$ & $\begin{array}{l}0.0040^{*} \\
(0.0024)\end{array}$ & & $\begin{array}{c}0.0038^{* *} \\
(0.0015)\end{array}$ \\
\hline Gini & & $\begin{array}{c}-0.4292^{* * *} \\
(0.0748)\end{array}$ & $\begin{array}{c}-0.5553^{* * *} \\
(0.1374)\end{array}$ & & $\begin{array}{c}-0.2565^{* *} \\
(0.1194)\end{array}$ \\
\hline Wealth index & & $\begin{array}{c}-0.0025 \\
(0.0104)\end{array}$ & $\begin{array}{c}-0.0916^{* * *} \\
(0.0278)\end{array}$ & & $\begin{array}{c}0.0295^{* *} \\
(0.0141)\end{array}$ \\
\hline Share of households with TV & & $\begin{array}{c}0.0052^{* * *} \\
(0.0006)\end{array}$ & $\begin{array}{l}-0.0010 \\
(0.0011)\end{array}$ & & $\begin{array}{c}0.0048^{* * *} \\
(0.0007)\end{array}$ \\
\hline year $==1982$ & $\begin{array}{c}0.3936^{* * *} \\
(0.0084)\end{array}$ & $\begin{array}{c}0.2030^{* * *} \\
(0.0146)\end{array}$ & $\begin{array}{c}0.3125^{* * *} \\
(0.0341)\end{array}$ & & \\
\hline Municipality FE & No & No & Yes & No & No \\
\hline Observations & 7428 & 7428 & 7428 & 3699 & 3699 \\
\hline R-squared & 0.18 & 0.31 & 0.79 & 0.01 & 0.27 \\
\hline Mean & 0.46 & 0.46 & 0.46 & 0.66 & 0.66 \\
\hline
\end{tabular}


voter turnout and the share of blank and null votes. Columns (1) and (3) present results of the estimates of equation 2.1 using municipality fixed-effects and time-varying controls for voter turnout and the share of blank and null votes, respectively. ${ }^{38}$ Results show that Globo's entry is (partially) uncorrelated to both variables.

Columns (2) and (4) present results of the estimates of equation 2.2 to the same set of variables. As in the case of ARENA's vote-share, the idea is to test if Globo's entry in a municipality is partially correlated with pre-existing differences in trends in electoral characteristics, using electoral outcomes in the elections from year $t-2$ and $t-1$. Different from the case of ARENA's vote-share, Globo's entry is correlated to changes in both voter turnout and share of blank and null votes. This is not a major concern for the strategy employed in this paper for two reasons. First, this specification does not allow the use of municipality fixed-effects and therefore, unobserved fixed characteristics that might be correlated with both electoral outcomes and Globo's entry are not absorbed and might be driving the results. Second, the magnitude of the effects is very small. An increase of 10 percentage points in voter turnout from $t-2$ to $t-1$, leads to a decrease of $1.9 \%$ in the probability of Globo's entry in the following period. A similar variation in the share of blank and null votes leads to an increase of $1.2 \%$ in the probability of Globo's entry.

Finally, Table 15 reports estimates of the placebo exercise described in Section 2.4.1. This exercise investigates not only the effect of Globo's past entry on current electoral outcomes, but the effects of its future entry. The regressor of interest in this case is Globo's coverage in $t+1$ that captures the effect of its future entry for areas not covered by its signal in $t$. The hypothesis is that electoral outcomes in places lacking the Globo signal should not be affected if the signal becomes available in the future. Columns (1)-(3) present the estimates when the dependent variable is ARENA's vote-share. The estimates reported in column (1) do not include neither municipality fixed-effects nor time-varying controls and show a significant effect of Globo in $t+1$ on current electoral outcomes. Column (2) includes time-varying controls, and the effect of the coefficient of interest remains significant. In column (3), however, municipality fixed-effects are included. ${ }^{39}$ In this specification, the significance of Globo's effect in $t+1$ on current ARENA vote-share disappears.

\footnotetext{
${ }^{38}$ Results of the estimates without time-varying controls and without municipality fixed effects are reported in Tables 34 and 35 in appendix B.

${ }^{39}$ Because this specification uses variables in $t+1$, the only elections available for use are from 1972 and 1976. As the data is not interpolated, using time-varying controls with municipality fixed-effects is impossible.
} 
Table 14: Possible selection in Globo coverage (Turnout and Share of blank and null votes)

Dependent variable $=1$ if Globo coverage in year $\mathrm{t}, \mathrm{t}=1976,1982$

\begin{tabular}{|c|c|c|c|c|}
\hline & \multicolumn{2}{|c|}{ Turnout } & \multicolumn{2}{|c|}{ Share of blank and null votes } \\
\hline & (1) & (2) & (3) & (4) \\
\hline Turnoutt-1 & $\begin{array}{c}0.0013 \\
(0.0011)\end{array}$ & & & \\
\hline$\Delta$ Turnout $_{\mathrm{t}-1, \mathrm{t}-2}$ & & $\begin{array}{c}-0.0019^{* *} \\
(0.0008)\end{array}$ & & \\
\hline Share of blank votes $\mathrm{t}_{\mathrm{t}-1}$ & & & $\begin{array}{c}0.0005 \\
(0.0009)\end{array}$ & \\
\hline$\Delta$ Blank + Null votest $t-2, \mathrm{t}-1$ & & & & $\begin{array}{c}0.0012^{* *} \\
(0.0006)\end{array}$ \\
\hline $\log$ (population) & $\begin{array}{c}-0.2748^{* * *} \\
(0.0429)\end{array}$ & $\begin{array}{c}-0.0486^{* * *} \\
(0.0078)\end{array}$ & $\begin{array}{c}-0.2744^{* * *} \\
(0.0430)\end{array}$ & $\begin{array}{c}-0.0491^{* * *} \\
(0.0078)\end{array}$ \\
\hline Share of pop living in urban areas & $\begin{array}{c}-0.0007 \\
(0.0013)\end{array}$ & $\begin{array}{l}-0.0007 \\
(0.0005)\end{array}$ & $\begin{array}{l}-0.0007 \\
(0.0013)\end{array}$ & $\begin{array}{c}-0.0008^{*} \\
(0.0005)\end{array}$ \\
\hline Income per capita (in min wages) & $\begin{array}{c}0.0705 \\
(0.0554)\end{array}$ & $\begin{array}{c}-0.0658^{* *} \\
(0.0298)\end{array}$ & $\begin{array}{c}0.0707 \\
(0.0555)\end{array}$ & $\begin{array}{c}-0.0629^{* *} \\
(0.0297)\end{array}$ \\
\hline Average years of schooling & $\begin{array}{l}0.0718^{*} \\
(0.0418)\end{array}$ & $\begin{array}{c}0.1245^{* * *} \\
(0.0214)\end{array}$ & $\begin{array}{c}0.0713^{*} \\
(0.0418)\end{array}$ & $\begin{array}{c}0.1238^{* * *} \\
(0.0214)\end{array}$ \\
\hline Life expectancy & $\begin{array}{c}0.0815^{* * *} \\
(0.0086)\end{array}$ & $\begin{array}{c}-0.0236^{* * *} \\
(0.0041)\end{array}$ & $\begin{array}{c}0.0812^{* * *} \\
(0.0087)\end{array}$ & $\begin{array}{c}-0.0235^{* * *} \\
(0.0041)\end{array}$ \\
\hline Infant mortality (per 1000) & $\begin{array}{c}0.0110^{* * *} \\
(0.0011)\end{array}$ & $\begin{array}{c}-0.0040^{* * *} \\
(0.0004)\end{array}$ & $\begin{array}{c}0.0110^{* * *} \\
(0.0011)\end{array}$ & $\begin{array}{c}-0.0040^{* * *} \\
(0.0004)\end{array}$ \\
\hline Share of illiterate over 15 y.o. & $\begin{array}{l}-0.0009 \\
(0.0018)\end{array}$ & $\begin{array}{l}0.0021^{*} \\
(0.0012)\end{array}$ & $\begin{array}{l}-0.0010 \\
(0.0018)\end{array}$ & $\begin{array}{c}0.0019 \\
(0.0012)\end{array}$ \\
\hline Share of employed people & $\begin{array}{c}0.0039 \\
(0.0024)\end{array}$ & $\begin{array}{c}0.0038^{* *} \\
(0.0015)\end{array}$ & $\begin{array}{l}0.0042^{*} \\
(0.0024)\end{array}$ & $\begin{array}{c}0.0037^{* *} \\
(0.0015)\end{array}$ \\
\hline Gini & $\begin{array}{c}-0.5512^{* * *} \\
(0.1372)\end{array}$ & $\begin{array}{c}-0.2477^{* *} \\
(0.1198)\end{array}$ & $\begin{array}{c}-0.5749^{* * *} \\
(0.1378)\end{array}$ & $\begin{array}{c}-0.2450^{* *} \\
(0.1196)\end{array}$ \\
\hline Wealth index & $\begin{array}{c}-0.0921^{* * *} \\
(0.0278)\end{array}$ & $\begin{array}{c}0.0316^{* *} \\
(0.0140)\end{array}$ & $\begin{array}{c}-0.0939^{* * *} \\
(0.0278)\end{array}$ & $\begin{array}{c}0.0287^{* *} \\
(0.0141)\end{array}$ \\
\hline Share of households with TV & $\begin{array}{c}-0.0009 \\
(0.0011)\end{array}$ & $\begin{array}{c}0.0047^{* * *} \\
(0.0007)\end{array}$ & $\begin{array}{l}-0.0010 \\
(0.0011)\end{array}$ & $\begin{array}{c}0.0047^{* * * *} \\
(0.0007)\end{array}$ \\
\hline year $==1982$ & $\begin{array}{c}0.3061^{* * *} \\
(0.0347)\end{array}$ & & $\begin{array}{c}0.3168^{* * *} \\
(0.0344)\end{array}$ & \\
\hline Municipality FE & Yes & No & Yes & No \\
\hline Observations & 7429 & 3700 & 7421 & 3692 \\
\hline R-squared & 0.79 & 0.27 & 0.79 & 0.27 \\
\hline Mean & 0.46 & 0.66 & 0.46 & 0.66 \\
\hline
\end{tabular}


Columns (4)-(6) present estimates of the same set of regressions for voter turnout and the results are similar. The significance of the coefficient associated with Globo's coverage in $t+1$ disappears after the inclusion of municipality fixed-effects. Finally, columns (7)-(9) report estimates using the share of blank and null votes as a dependent variable. In this case, the effect of Globo's coverage in $t+1$ is not significant in any specification.

This section provided evidence that the key assumption (i.e., Globo's entry in a municipality is uncorrelated with pre-existing differences in political characteristics across municipalities) holds after controlling for time-varying controls and time-invariant characteristics of the municipality.

\subsubsection{Main results}

This section reports results of the main estimates of this chapter, the effect of Globo on mayoral elections in 1972, 1976, and 1982. If the hypothesis holds that Globo was captured during the military regime, then one should expect to see a positive effect of Globo on the ruling party's vote-share.

Table 16 reports estimates of Equation 2.4 using ARENA's vote-share as the dependent variable. The first three columns report the average effect of having Globo's signal on ARENA's vote-share in the three municipal elections between 1972 and 1982. Estimates in column (1) show a strong and highly significant negative effect on ARENA vote-share of having Globo's signal. This specification does not include time-varying controls and municipality fixed-effects. Therefore, as discussed in the previous section, is not free of the selection effects. Column (2) shows the estimates including time-varying controls. As expected, the effects associated with having Globo's signal decrease substantially. Column (3), finally, presents estimates of the more complete specification, including time-varying controls and municipality fixed-effects - replicating the specification used in the previous section to provide evidence that Globo's entry is partially uncorrelated to ARENA's previous vote-share. The results showing a negative effect of Globo on the ruling party's vote-share contradict the hypothesis that Globo was captured and being used by the central government to broadcast political propaganda in favor of the regime, at least during the entire period.

To better understand these results, columns (4) - (6) present results of estimates testing 


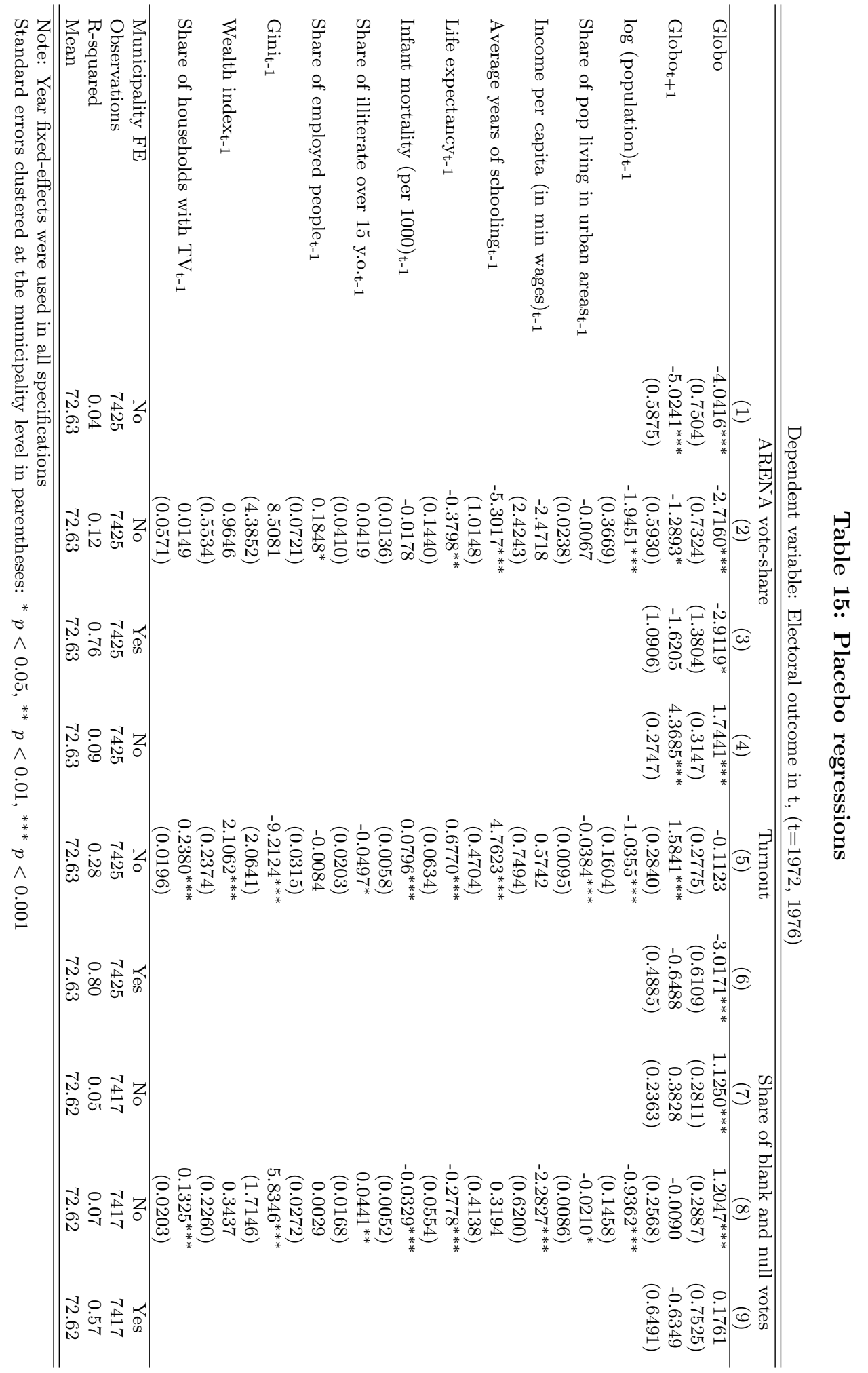


the hypothesis that the effect of Globo differs each year. Columns (4) and (5) repeat the specifications used in columns (1) and (2) and are therefore not completely free of the selection effect. Column (6) shows the more complete specification, similar to that shown in column (4), and shows that the effect on ARENA's vote-share of having Globo's signal differs in the three elections. In particular, the effect on the 1972 mayoral election is positive and highly significant. ARENA's vote-share in a municipality having Globo's signal in this election was $4.15 \%$ higher than in a municipality where Globo's signal was not yet available. In the 1976 and 1982 mayoral elections, the presence of Globo's signal in a municipality is associated with a vote-share around $2.3 \%$ lower for ARENA. These results suggest that the bias of Globo changed between 1972 and 1976. Although this is consistent with the discussion of previous sections, it warrants a deeper investigation.

Table 16: Effect of Globo on ARENA's vote-share

\begin{tabular}{|c|c|c|c|c|c|c|}
\hline & $(1)$ & $(2)$ & $(3)$ & (4) & $(5)$ & $(6)$ \\
\hline Globo & $\begin{array}{c}-9.2289^{* * *} \\
(0.5742)\end{array}$ & $\begin{array}{c}-2.5551^{* * *} \\
(0.5599)\end{array}$ & $\begin{array}{c}-1.5995^{* *} \\
(0.7433)\end{array}$ & & & \\
\hline Globo $*$ year $==1972$ & & & & $\begin{array}{c}-3.1095^{* *} \\
(1.3042)\end{array}$ & $\begin{array}{c}1.9316 \\
(1.3189)\end{array}$ & $\begin{array}{c}4.1509^{* * *} \\
(1.5807)\end{array}$ \\
\hline Globo $*$ year $==1976$ & & & & $\begin{array}{c}-8.3788^{* * *} \\
(0.7808)\end{array}$ & $\begin{array}{c}-4.4782^{* * *} \\
(0.7371)\end{array}$ & $\begin{array}{c}-2.3052^{* * *} \\
(0.8633)\end{array}$ \\
\hline Globo $*$ year $==1982$ & & & & $\begin{array}{c}-11.9582^{* * *} \\
(0.7389)\end{array}$ & $\begin{array}{c}-2.3898^{* * *} \\
(0.7273)\end{array}$ & $\begin{array}{c}-2.3496^{* *} \\
(1.0572)\end{array}$ \\
\hline $\log$ (population) & & $\begin{array}{c}-2.1326^{* * *} \\
(0.2890)\end{array}$ & $\begin{array}{c}-6.1464^{* * *} \\
(1.5433)\end{array}$ & & $\begin{array}{c}-2.1327^{* * *} \\
(0.2900)\end{array}$ & $\begin{array}{c}-5.9652^{* * *} \\
(1.5486)\end{array}$ \\
\hline Share of pop living in urban areas & & $\begin{array}{c}-0.0311^{*} \\
(0.0177)\end{array}$ & $\begin{array}{c}-0.1896^{* * *} \\
(0.0512)\end{array}$ & & $\begin{array}{c}-0.0338^{*} \\
(0.0178)\end{array}$ & $\begin{array}{c}-0.1911^{* * *} \\
(0.0510)\end{array}$ \\
\hline Income per capita (in min wages) & & $\begin{array}{c}-5.4077^{* * *} \\
(1.3805)\end{array}$ & $\begin{array}{l}-3.1165 \\
(2.1199)\end{array}$ & & $\begin{array}{c}-5.3800^{* * *} \\
(1.3821)\end{array}$ & $\begin{array}{l}-2.7707 \\
(2.1111)\end{array}$ \\
\hline Average years of schooling & & $\begin{array}{c}-5.7188^{* * *} \\
(0.7575)\end{array}$ & $\begin{array}{c}-6.2016^{* * *} \\
(1.5759)\end{array}$ & & $\begin{array}{c}-5.6901^{* * *} \\
(0.7576)\end{array}$ & $\begin{array}{c}-6.1356^{* * *} \\
(1.5729)\end{array}$ \\
\hline Life expectancy & & $\begin{array}{c}0.0171 \\
(0.1232)\end{array}$ & $\begin{array}{c}-0.6596^{* *} \\
(0.3355)\end{array}$ & & $\begin{array}{c}0.0342 \\
(0.1231)\end{array}$ & $\begin{array}{c}-0.6573^{*} \\
(0.3386)\end{array}$ \\
\hline Infant mortality (per 1000) & & $\begin{array}{c}0.0137 \\
(0.0122)\end{array}$ & $\begin{array}{l}-0.0461 \\
(0.0464)\end{array}$ & & $\begin{array}{c}0.0140 \\
(0.0122)\end{array}$ & $\begin{array}{l}-0.0471 \\
(0.0469)\end{array}$ \\
\hline Share of illiterate over 15 y.o. & & $\begin{array}{c}0.0242 \\
(0.0332)\end{array}$ & $\begin{array}{l}-0.0133 \\
(0.0722)\end{array}$ & & $\begin{array}{c}0.0246 \\
(0.0333)\end{array}$ & $\begin{array}{l}-0.0145 \\
(0.0721)\end{array}$ \\
\hline Share of employed people & & $\begin{array}{l}0.1154^{* *} \\
(0.0542)\end{array}$ & $\begin{array}{c}0.0542 \\
(0.0918)\end{array}$ & & $\begin{array}{l}0.1155^{* *} \\
(0.0541)\end{array}$ & $\begin{array}{c}0.0532 \\
(0.0918)\end{array}$ \\
\hline Gini & & $\begin{array}{c}9.3351^{* * *} \\
(3.5158)\end{array}$ & $\begin{array}{c}5.1441 \\
(5.5809)\end{array}$ & & $\begin{array}{l}8.9672^{* *} \\
(3.5159)\end{array}$ & $\begin{array}{c}4.0623 \\
(5.5825)\end{array}$ \\
\hline Wealth index & & $\begin{array}{l}-0.5772 \\
(0.4434)\end{array}$ & $\begin{array}{l}-0.8268 \\
(1.0294)\end{array}$ & & $\begin{array}{l}-0.6881 \\
(0.4437)\end{array}$ & $\begin{array}{l}-0.6910 \\
(1.0303)\end{array}$ \\
\hline Share of households with TV & & $\begin{array}{l}-0.0407 \\
(0.0264)\end{array}$ & $\begin{array}{c}-0.0947^{* *} \\
(0.0411)\end{array}$ & & $\begin{array}{l}-0.0451^{*} \\
(0.0267)\end{array}$ & $\begin{array}{c}-0.0861^{* *} \\
(0.0416)\end{array}$ \\
\hline year $==1976$ & $\begin{array}{c}-3.6512^{* * *} \\
(0.3672)\end{array}$ & $\begin{array}{c}-4.7784^{* * *} \\
(0.3637)\end{array}$ & $\begin{array}{c}-4.8821^{* * *} \\
(0.4525)\end{array}$ & $\begin{array}{c}-3.3562^{* * *} \\
(0.4075)\end{array}$ & $\begin{array}{c}-3.9239^{* * *} \\
(0.4001)\end{array}$ & $\begin{array}{c}-4.2266^{* * *} \\
(0.4856)\end{array}$ \\
\hline year $==1982$ & $\begin{array}{c}-12.5453^{* * *} \\
(0.5434)\end{array}$ & $\begin{array}{c}-8.4356^{* * *} \\
(0.7195)\end{array}$ & $\begin{array}{c}-4.5448 * * * \\
(1.4619)\end{array}$ & $\begin{array}{c}-10.2406^{* * *} \\
(0.6555)\end{array}$ & $\begin{array}{c}-8.1615^{* * *} \\
(0.7562)\end{array}$ & $\begin{array}{c}-4.0020^{* * *} \\
(1.4999)\end{array}$ \\
\hline Municipality FE & No & No & Yes & No & No & Yes \\
\hline Observations & 11206 & 11206 & 11206 & 11206 & 11206 & 11206 \\
\hline R-squared & 0.14 & 0.26 & 0.69 & 0.14 & 0.26 & 0.69 \\
\hline Mean & 67.48 & 67.48 & 67.48 & 67.48 & 67.48 & 67.48 \\
\hline
\end{tabular}

Before moving to better understanding the previous findings, however, the effects of Rede Globo on other electoral outcomes should be evaluated; Results of the estimates of the 
complete specification of equation 2.4 using voter turnout and the share of blank and null votes as dependent variables are presented in Table $17 .{ }^{40}$ The average effect of Globo on these voter outcomes is statistically zero, as seen in the coefficients in columns (1) and (3). However, as Globo's role over time changed dramatically, testing for heterogeneous effects across different elections for these variables is also required. These results are reported in columns (2) and (4). The effect of Globo on voter turnout changes greatly over different elections. In 1972, the point estimate is negative, but the effect is not significant, probably due to the small number of municipalities with Globo's signal at the time. In 1976, the point estimate is still negative, but smaller and significant. In 1982, the effect becomes positive and highly significant, suggesting the influence of television in the political process increased over time. The effects on the share of blank and null votes are zero in the three elections studied.

Table 17: Effect of Globo on turnout and share of blank and null votes

\begin{tabular}{|c|c|c|c|c|}
\hline & Tur & out & Share of blank and null votes & \\
\hline & $(1)$ & $(2)$ & $(3)$ & (4) \\
\hline Globo & $\begin{array}{c}0.1308 \\
(0.3110)\end{array}$ & & $\begin{array}{l}-0.1048 \\
(0.3239)\end{array}$ & \\
\hline Globo $*$ year $==1972$ & & $\begin{array}{l}-0.9373 \\
(0.5757)\end{array}$ & & $\begin{array}{l}-0.2052 \\
(0.8041)\end{array}$ \\
\hline Globo $*$ year $==1976$ & & $\begin{array}{c}-0.7704^{* *} \\
(0.3254)\end{array}$ & & $\begin{array}{l}-0.0504 \\
(0.3922)\end{array}$ \\
\hline Globo $*$ year $==1982$ & & $\begin{array}{c}1.2665^{* * *} \\
(0.4466)\end{array}$ & & $\begin{array}{l}-0.1323 \\
(0.4088)\end{array}$ \\
\hline $\log$ (population) & $\begin{array}{c}-2.8995^{* * *} \\
(0.6664)\end{array}$ & $\begin{array}{c}-2.7589^{* * *} \\
(0.6614)\end{array}$ & $\begin{array}{c}2.2367^{* * *} \\
(0.5525)\end{array}$ & $\begin{array}{c}2.2264^{* * *} \\
(0.5538)\end{array}$ \\
\hline Share of pop living in urban areas & $\begin{array}{l}-0.0276 \\
(0.0191)\end{array}$ & $\begin{array}{l}-0.0285 \\
(0.0189)\end{array}$ & $\begin{array}{c}0.0210 \\
(0.0175)\end{array}$ & $\begin{array}{c}0.0211 \\
(0.0175)\end{array}$ \\
\hline Income per capita (in min wages) & $\begin{array}{c}1.9884^{* * *} \\
(0.5792)\end{array}$ & $\begin{array}{c}1.7987^{* * *} \\
(0.5832)\end{array}$ & $\begin{array}{c}-2.0102^{* * *} \\
(0.5920)\end{array}$ & $\begin{array}{c}-2.0111^{* * *} \\
(0.5933)\end{array}$ \\
\hline Average years of schooling & $\begin{array}{l}-0.7347 \\
(0.6424)\end{array}$ & $\begin{array}{l}-0.7005 \\
(0.6394)\end{array}$ & $\begin{array}{c}0.8541 \\
(0.6209)\end{array}$ & $\begin{array}{c}0.8511 \\
(0.6209)\end{array}$ \\
\hline Life expectancy & $\begin{array}{c}0.3350^{* *} \\
(0.1345)\end{array}$ & $\begin{array}{c}0.2791^{* *} \\
(0.1352)\end{array}$ & $\begin{array}{c}-0.2930^{* *} \\
(0.1336)\end{array}$ & $\begin{array}{c}-0.2908^{* *} \\
(0.1349)\end{array}$ \\
\hline Infant mortality (per 1000) & $\begin{array}{c}0.0432^{* *} \\
(0.0188)\end{array}$ & $\begin{array}{l}0.0359^{*} \\
(0.0189)\end{array}$ & $\begin{array}{c}-0.0442^{* *} \\
(0.0180)\end{array}$ & $\begin{array}{c}-0.0438^{* *} \\
(0.0182)\end{array}$ \\
\hline Share of illiterate over 15 y.o. & $\begin{array}{l}-0.0569^{*} \\
(0.0318)\end{array}$ & $\begin{array}{l}-0.0569^{*} \\
(0.0318)\end{array}$ & $\begin{array}{l}0.0532^{*} \\
(0.0296)\end{array}$ & $\begin{array}{l}0.0532^{*} \\
(0.0296)\end{array}$ \\
\hline Share of employed people & $\begin{array}{c}0.0295 \\
(0.0375)\end{array}$ & $\begin{array}{c}0.0273 \\
(0.0376)\end{array}$ & $\begin{array}{l}-0.0335 \\
(0.0332)\end{array}$ & $\begin{array}{l}-0.0333 \\
(0.0332)\end{array}$ \\
\hline Gini & $\begin{array}{c}-8.4621^{* * *} \\
(2.2927)\end{array}$ & $\begin{array}{c}-7.7513^{* * *} \\
(2.2978)\end{array}$ & $\begin{array}{l}-0.4997 \\
(2.2002)\end{array}$ & $\begin{array}{l}-0.5011 \\
(2.1951)\end{array}$ \\
\hline Wealth index & $\begin{array}{l}-0.0521 \\
(0.3978)\end{array}$ & $\begin{array}{l}-0.1358 \\
(0.3971)\end{array}$ & $\begin{array}{c}1.0406^{* * *} \\
(0.3754)\end{array}$ & $\begin{array}{c}1.0406^{* * *} \\
(0.3770)\end{array}$ \\
\hline Share of households with TV & $\begin{array}{c}-0.0466^{* * *} \\
(0.0148)\end{array}$ & $\begin{array}{c}-0.0601^{* * *} \\
(0.0153)\end{array}$ & $\begin{array}{c}0.0095 \\
(0.0144)\end{array}$ & $\begin{array}{c}0.0098 \\
(0.0149)\end{array}$ \\
\hline year $==1976$ & $\begin{array}{c}3.9650^{* * *} \\
(0.2012)\end{array}$ & $\begin{array}{c}4.1023^{* * *} \\
(0.2218)\end{array}$ & $\begin{array}{c}-4.2058^{* * *} \\
(0.2624)\end{array}$ & $\begin{array}{c}-4.2278^{* * *} \\
(0.2851)\end{array}$ \\
\hline year $==1982$ & $\begin{array}{c}4.9059^{* * *} \\
(0.5816) \\
\end{array}$ & $\begin{array}{c}4.4822^{* * *} \\
(0.5956) \\
\end{array}$ & $\begin{array}{c}-1.4751^{* *} \\
(0.5734)\end{array}$ & $\begin{array}{c}-1.4715^{* *} \\
(0.5819) \\
\end{array}$ \\
\hline Municipality FE & Yes & Yes & Yes & Yes \\
\hline Observations & 11209 & 11209 & 11200 & 11200 \\
\hline R-squared & 0.72 & 0.72 & 0.43 & 0.43 \\
\hline Mean & 79.91 & 79.91 & 8.45 & 8.45 \\
\hline
\end{tabular}

\footnotetext{
${ }^{40}$ The complete set of results is presented in appendix B, Tables 36 and 37.
} 


\subsubsection{Heterogeneity by socioeconomic characteristics}

This subsection analyzes the possibility that the effects of exposure to Globo may be heterogeneous along the dimensions of education - measured by average years of schooling - and the share of households with televisions in the municipality. The idea behind this tests is to provide more clear evidence that the effects documented in the previous tables are indeed related to the presence of Globo. As already discussed, if one crucial reason behind television's influence in Brazil is the strength of the country's oral tradition, the effect of Globo should be more accentuated in municipalities with lower average years of schooling. Also, if the effect is indeed related to television, it should also be more accentuated in municipalities with a higher share of households with television.

Because the effect of Globo is heterogeneous on the year dimension, Equation 2.5 is estimated with interaction with year dummies. Time-varying control, municipality and year fixed-effects and all relevant interactions, though not reported, are included in the regressions. Results are shown in Table 18. Column (1) presents the estimates interacting average years of schooling at the municipality with the presence of Globo. According to what has been discussed, Globo's effect is expected to be less emphasized in municipalities with higher average years of schooling. However, whether this is true is not clear. The effect in 1972, for instance, is stronger in municipalities with higher average of years of schooling.

Column (2) shows estimates interacting the share of households with televisions with the presence of Globo. In this case, the coefficients associated with the interactions should go in the same direction as the coefficients associated with the Globo effect itself. Again, this may not be the case. The effect in 1982 is weaker in municipalities with a higher share of households with televisions.

One possible reason for these unclear results might be that average years of schooling at the municipality level and the share of households with televisions are highly positively correlated $^{41}$ but are expected to have different effects in the interaction with Globo. To overcome this possible issue of omitted variable bias, the estimation is done including the interactions with both observables. The results shown in column (3) are much more intuitive, even though most coefficients are not statistically significant when tested indi-

\footnotetext{
${ }^{41}$ In fact, the correlation between these two variables is 0.825 in the estimating sample.
} 
vidually due to low power. These results, therefore, reinforce the idea that the findings documented in the previous section are related to the presence of Globo in the municipality.

Table 18: Heterogeneous effect (Share of households with televisions and average schooling)

\begin{tabular}{|c|c|c|c|}
\hline & (1) & $(2)$ & $(3)$ \\
\hline \multirow[t]{2}{*}{ Globo * 1972} & 0.0063 & 0.4786 & 1.9636 \\
\hline & $(3.1638)$ & $(2.0678)$ & $(3.3443)$ \\
\hline \multirow[t]{2}{*}{ Globo * 1976} & -2.3499 & -1.6705 & -2.7116 \\
\hline & $(1.6366)$ & $(1.2484)$ & $(1.6830)$ \\
\hline \multirow[t]{2}{*}{ Globo * 1982} & $-5.3251^{* * *}$ & $-2.9365^{* *}$ & $-6.0251^{* * *}$ \\
\hline & $(1.5559)$ & $(1.2286)$ & $(1.6569)$ \\
\hline \multirow[t]{2}{*}{ Globo * schooling * 1972} & 2.3124 & & -2.1285 \\
\hline & $(2.1432)$ & & $(3.2173)$ \\
\hline \multirow[t]{2}{*}{ Globo * schooling * 1976} & 0.4370 & & 1.4842 \\
\hline & $(0.9239)$ & & $(1.5640)$ \\
\hline \multirow[t]{2}{*}{ Globo * schooling * 1982} & $3.4517^{* * *}$ & & $5.4372^{* * *}$ \\
\hline & $(1.0399)$ & & $(1.8749)$ \\
\hline \multirow[t]{2}{*}{ Globo * \% tv * 1972} & & $0.2181^{* *}$ & $0.3003^{* *}$ \\
\hline & & $(0.1004)$ & $(0.1521)$ \\
\hline \multirow[t]{2}{*}{ Globo * \% tv * 1976} & & -0.0032 & -0.0704 \\
\hline & & $(0.0524)$ & $(0.0889)$ \\
\hline \multirow[t]{2}{*}{ Globo $* \%$ tv $* 1982$} & & $0.0902^{*}$ & -0.1084 \\
\hline & & $(0.0472)$ & $(0.0859)$ \\
\hline Mean & 67.45 & 79.95 & 8.45 \\
\hline Observations & 11101 & 11101 & 11101 \\
\hline R-squared & 0.69 & 0.69 & 0.69 \\
\hline
\end{tabular}

\subsubsection{Heterogeneity by television content (novelas)}

This section proceeds to investigate more closely the reasons for the heterogeneous effects by year documented in the previous sections. As discussed at the start of the chapter, the literature suggests that the posture adopted by Globo over the years toward the dictatorship changed and therefore, the content of its daily programs changed as well. In order to formally test the hypothesis that the change in television content led to different media effects on electoral outcomes, the content of all novelas aired between 1965 and 1982 were coded.

As a first piece of evidence, Figure 9 plots the estimated effect of Globo on ARENA's vote-share in each election and the share of novelas with political content in each period. The effect of Globo on ARENA's vote-share clearly moves in an opposite direction than the number of novelas having political issues discussed in the main plot.

The hypothesis that the content of the novelas explains the heterogeneous effects associated with Globo is formally tested by estimating equation 2.6. The results are shown 


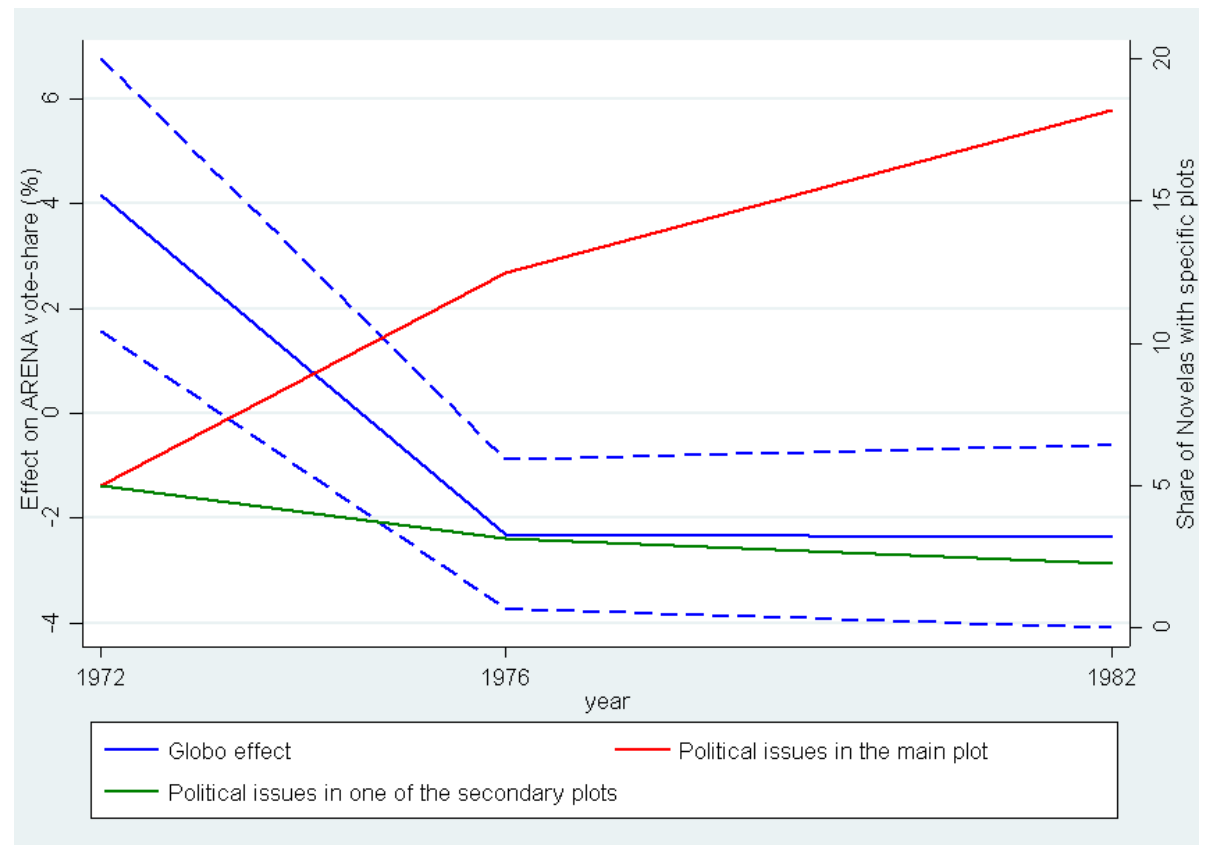

Figure 9: Effect of Globo on ARENA's vote-share vs share of novelas with political content

in Table 19. In all regressions, time-varying controls, year and municipality fixed-effects are included. For convenience, only the coefficients associated with the Globo dummy, with the share of days exposed to Globo in each electoral cycle and with the share of time exposed to an specific content are presented. ${ }^{42}$ Panel A and B present the results of estimates for political-related content, while Panel $\mathrm{C}$ presents the results for non-political contents.

As seen in Panel A, being exposed to the majority of political related contents has a negative effect on ARENA's vote-share. Column (1) reports the effect of being exposed to a novela that discusses political issues, regardless doing it in the main or in the secondary plot. Conditional on having Globo's signal in the municipality, an increase of 10 percentage points in the share of time exposed to a novela discussing political issues decreases ARENA's vote-share by $3.44 \%{ }^{43}$ Considering only novelas discussing political issues in the main plot, the effect is similar. An increase in 10 percentage points corresponds to a decrease of $3.03 \%$ in ARENA's vote-share. The estimated effect of being exposed to novelas discussing political issues in the secondary plot is negative but this coefficient is estimated with impression due to small variation in this measure. ${ }^{44}$

\footnotetext{
${ }^{42}$ Table 38, in appendix B reports the estimates using a different measure of novela content, the number of novelas with specific plots between elections in $\mathrm{t}-1$ and $\mathrm{t}$.

${ }^{43}$ According to the figures presented in Table 12, 10 percentage points is roughly the increase in the share of novelas discussing political issues between the period preceding 1972 elections and the period preceding 1982 elections.

${ }^{44}$ The share of novelas discussing political issues in the secondary plot changes from $5 \%$ to $2.27 \%$
} 
Still in Panel A, the results of being exposed to a novela with a character in opposition to the ruling party or to a political powerful group are presented in columns (4) and (5). If the novela have a main character of this type, the effect on ARENA's vote-share is negative; an increase of 10 percentage points in the share of time exposed reduces ARENA's vote-share by $4.41 \%$. On the other hand, if the novela has a "political character" who is not its main character, the same variation in exposure time is associated with an increase of $7.15 \%$ on ARENA's vote-share. Although counterintuitive, this result can be easily understand by looking at Figure 9 and at Table 12. Over time, a substitution clearly occurred in which the number of novelas discussing political issues in the main plot increased, and the number of novelas discussing political issues in their seconday plots decreased. The result in column (5), therefore, can be understand as been a result of omitting the measure of exposure used in column (4).

Panel B shows the effects of exposure to novelas discussing specific political issues. Exposure to all the listed issues have a negative and significant effect on ARENA's vote-share. Interestingly, novelas that discuss demand for democracy are among the ones with higher (negative) effect on ARENA's vote-share.

Panel C, in turn, shows the effects of exposure to issues that are not necessarily connected to politics. Excluding novelas that have rural plots and those discussing slavery, exposure to other issues have no significant effects on ARENA's vote-share. Note that the interaction of measures of novela content with Globo are estimated separately; therefore, the negative effects of non-political-related issues do not necessarily mean that novelas with rural plots per se are directly causing a negative effect on ARENA's vote-share. It may be the case that a relevant part of the novelas discussing political issues took place in a rural setting. ${ }^{45}$

\subsection{Conclusion}

This chapter investigated the presence of media capture during the Brazilian dictatorship. This was accomplished by evaluating the effects of Globo, the main Brazilian television station, on mayoral electoral outcomes during in the 1970s and 1980s.

\footnotetext{
between the period preceding 1972 elections and the one preceding 1982 elections.

${ }^{45}$ Indeed, this is the case of some of novelas that discussed political issues; for example, the case of $O$ Bem Amado and Irmãos Coragem.
} 


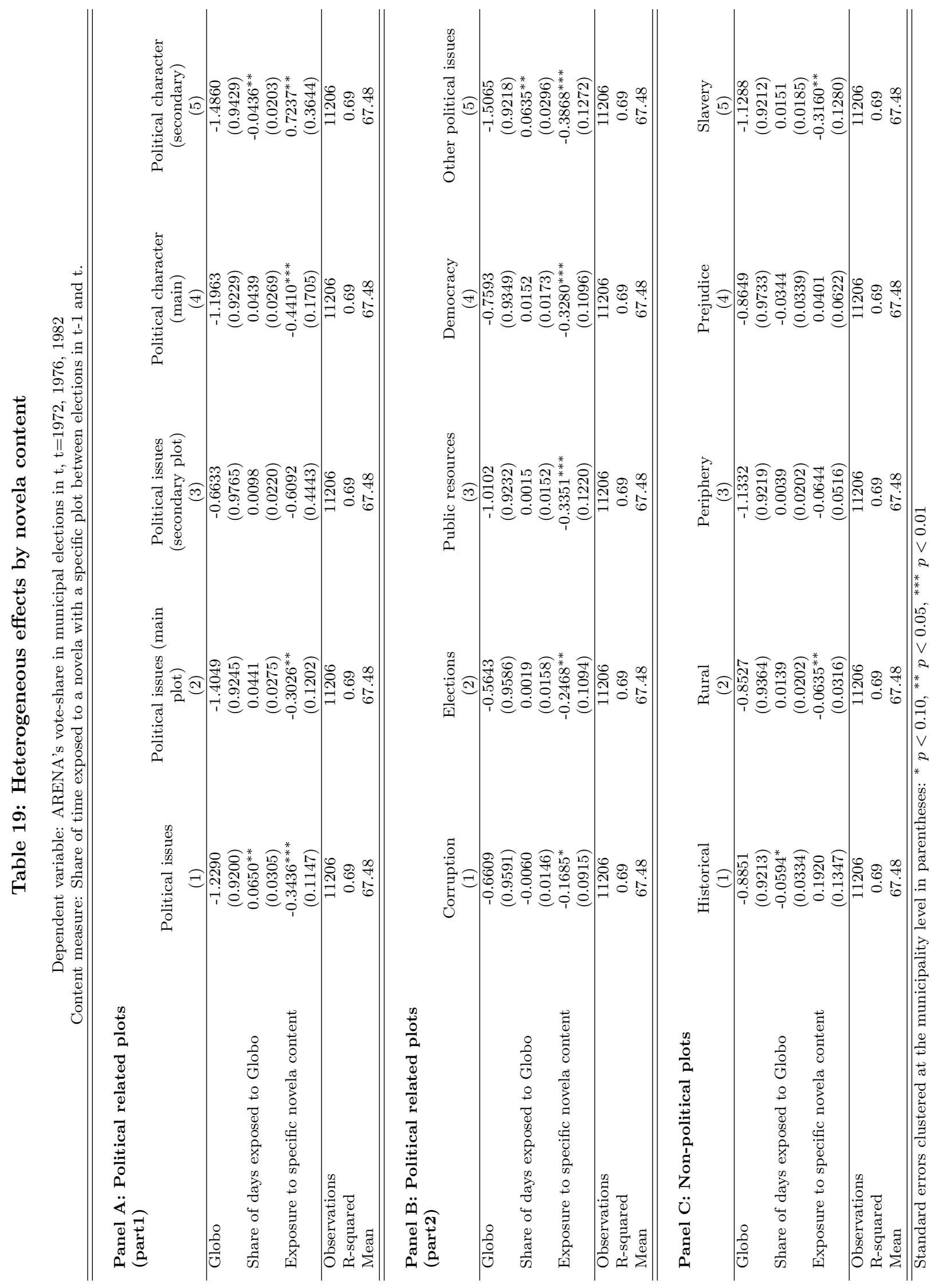


To identify such effects, this chapter explored differences in the timing of Globo's entry into different municipalities. The main empirical challenge is that Globo's entry could be correlated with political preferences at the municipality level. Evidence provided in this chapter shows that conditional on a set of municipality-level controls as well as municipality and year fixed-effects, there is no evidence of a politically driven entry of Globo.

The main results show that Globo has an average negative effect on ARENA's voteshare in the three mayoral elections occurring between 1972 and 1982 . This effect is heterogeneous in the year dimension. Globo has a positive effect on ARENA's vote-share in the first elections studied in this chapter, in 1972, and then in the later years, the effect becomes negative. In order to better understand this shifting in the effect of Globo, the content of Brazilian novelas were coded and used in the analysis. The result of the regressions using this data show that exposure to novelas with politically-related content has a negative effect on ARENA's vote-share.

These results are consistent with the anecdotal evidence suggesting that in response to the new context of political and economic crisis, Globo assumed a critical role in the last years of the regime. They are also consistent with a theoretical result by Prat \& Strömberg (2011), according to which the presence of a news-related profit motive makes political capture of media vehicles more difficult to happen. 


\section{POLITICAL PREACHING IN THE CLASSROOM: EVIDENCE FROM TEACHERS' PARTY AFFILIATION IN BRAZILIAN PUBLIC SCHOOLS}

\subsection{Introduction}

Frequently regarded as one of the crucial inputs in the educational process (Rockoff (2004)), teachers commonly stand among the politically engaged groups with the most influence on shaping essential public policies and on promoting economic and social development. ${ }^{46}$ However, a seemingly underappreciated topic by both the economics and political science literatures has been the role that politically active teachers might perform in political environments and especially the influence they may exert on the electoral process. Despite the suggestion by contemporary observers that faculty would be indoctrinating students with certain politically bent education (Horowitz (2006)), the literature on political behavior has focused on exploring the effect on students' political attitudes stemming from education acquisition as a whole (Persson (2014), Kam \& Palmer (2008a)), with no special regard for the particular influence of partisan political preaching by teachers with strong political views. It seems natural to think, though, that while facing great audiences of recently registered voters and individuals that just got into political questioning, teachers may play a unique and important part not only in their students' political (and partisan) stances, but also in the configuration of electoral outcomes. At the very least, they hold a prime position to discuss political matters with their students; however, they could also present themselves as self-appointed party delegates trying to deliver their students' votes, or even as political power brokers involved in clientelistic relationships $^{47}$ - especially in the developing world, where these practices tend to be widespread. ${ }^{48}$ Notwithstanding, little has been reported on the extent to which teachers are able to influence voting behavior.

This chapter investigates this issue by looking at the effects of the presence of partyaffiliated teachers on certain regions' electoral outcomes. Merging a unique individual level database of public high school teachers in São Paulo, Brazil, with an individual level database of party-affiliated voters, it is possible to identify high school teachers' politi-

\footnotetext{
${ }^{46}$ In the context of teachers' unionisation, for instance, it has been argued that the acquisition of bargaining power by such agents may have important consequences on resource allocation in public schools (Hoxby (1996); Moe (2011)).

${ }^{47}$ The case for contexts of education provision as particularly prone for the flourishing of patronage is made by Corrales (2006), for instance.

${ }^{48}$ See, for instance, Kitschelt \& Wilkinson (2007) and Schaffer (2007).
} 
cal affiliations. Furthermore, a very rich database of electoral outcomes and electorate characteristics is exploited to investigate the relationship between the density of affiliated teachers and the electoral outcomes at a highly disaggregated geographic level, which allows to get high precision estimates and avoid certain endogeneity issues.

The matter of such an influence by teachers poses as a very relevant question for two main reasons. First, while it may be hard to believe that teachers alone are able to change the outcome of a plurality election by influencing their students' voting behaviour, the same is not true for proportional elections, in which the number of votes necessary for being elected might be much smaller, especially in small municipalities. The second reason relies on the fact that evidence on such influence would be a sign that teachers are diverging from the curriculum content standards, which may not only affect electoral outcomes, but also have deleterious effects on education outcomes. ${ }^{49}$

This research is presented with important empirical challenges, especially concerning the matter of selection in the assignment of teachers to schools. To overcome this issue, the varying intensity of the hypothesized effect according to electorate characteristics at the polling station level, the specific place in the polling district where each voter is designed to cast his or her vote, is exploited. The underlying hypothesis is that teachers - or voters in general - are not able to select themselves at that level in any manner, and thus controlling for specific characteristics of regions where selection may yet occur should render estimates free of that kind of selection bias. Evidence of a positive and significant effect of the presence of affiliated teachers on the electoral performance of the corresponding party through influencing their voting-aged students is found. Moreover, the results show this effect is more pronounced in plurality elections and appear to be restricted to teachers affiliated to the Workers' Party. For that party, it is also found evidence that affiliated teachers do not have an impact on electoral turnout by students; rather, these teachers are suggested to alter the political preferences of students that would vote for another party.

This paper communicates with at least two different strands of the political economy and political science literatures, as well as to the education literature. First, it is closely related to studies focused on exploring the relationship between education and political participation. Extensive research on this topic has traditionally documented a strong and

\footnotetext{
${ }^{49}$ In the context of unionisation, deleterious effects on student performance have been documented by Hoxby (1996) and Eberts \& Stone (1987).
} 
positive relationship between schooling and political participation: Hillygus (2005), Nie, Junn \& Stehlik-Barry (1996) and Wolfinger \& Rosenstone (1980), for instance, suggest the connection of higher education to an enhanced voter turnout, political knowledge and civic engagement. ${ }^{50}$ On the other hand, a more rigid exploration of the corresponding causal link has only been developed by more recent work, with mixed findings. While Dee (2004) and Milligan, Moretti \& Oreopoulos (2004) find a positive effect using U.S. and U.K. data, Persson (2014) and Kam \& Palmer (2008b) using data from the same countries, and Solis (2013) using data from Chile suggest that the relationship between education and political participation is spurious.

Differently from that literature, however, this paper aims to study the influence of specific behavior by a particular group of teachers, namely the political indoctrination of students by their party-affiliated teachers. In this sense, this work is also related to the literature on education as fundamentally a political process and on teachers' behavior in classroom situations. ${ }^{51}$ Under a comparative education approach, Hahn (1998) and Westheimer \& Kahne (2008) argue that diversified practices of citizenship education arguably the subject area most favorable to engagement with political issues - are highly influenced by national political scenarios and driven by different beliefs about democracy, while Schugurensky \& Myers (2003) stress teachers' political participation as an important consideration for understanding such practices. In a case study of Brazilian and Canadian secondary teachers, Myers (2007) illustrates the influence of political participation - measured according to involvement in teachers' unions, political parties and social movements - on both pedagogical and curricular approaches.

Lastly, the present work is also related to the political clientelism literature, which explores how and under what conditions certain agents - voters or political power brokers trade their political support during elections, as well as the inefficiencies stemming from their corresponding rewards. In the context of developing countries, for instance, Finan (2004) presents an example of that practice by arguing that federal deputies in Brazil reward municipalities based on their political support. Regarding the Brazilian educational context, Mainwaring (1999) reports that, as a result of clientelism, in the state of Bahia about 37,000 teachers who were on the public payroll in 1987 had never taught a single class. On the other hand, the more specific analysis of the situations in which political brokers may arise - and what kind of individuals are more likely to play that role

\footnotetext{
${ }^{50}$ This hypothesized effect of educational attainment has sometimes been used to advocate government intervention in the education market (Hanushek (2002)).

${ }^{51}$ See also Ginsburg et al. (1992).
} 
- and act to influence electoral outcomes as middlemen between political parties and large groups of voters seems not yet thoroughly developed nor fully understood. One exception is provided by Larreguy (2013), where the establishment of clientelistic networks by communal land leaders in Mexico serves as the basis for an investigation of the monitoring capabilities presented by political parties in securing their votes.

The remainder of this chapter is organized as follows. Section 3.2 describes voting procedures in Brazilian elections and the assignment of teachers and students to public schools in São Paulo. Section 3.3 describes the data and the empirical strategy. Sections 3.4 and 3.5 discuss the main results, and Section 3.6 concludes.

\subsection{Institutional Background}

This section highlights the main features of the Brazilian electoral system and characterize the public education system in the state of São Paulo ${ }^{52}$ - for which data on teachers are available - placing particular emphasis on the rules governing student and teacher placement in public schools.

\subsubsection{Voting in Brazil}

Brazilian states and municipalities have autonomous administrations, and both executive leaders and local legislatures are elected by direct elections. Voting is mandatory for literate citizens aged 18-70 and facultative for citizens between 16 and 17 or over 70, and for illiterate people. Elections in Brazil are held every four years. Elections for president, senators, deputies and governors are held jointly while elections for mayors and city councilmen are staggered by two years relative to general elections.

In order to better organize election procedures, each state is divided into polling districts (Zona Eleitoral) which are, in their turn, composed of several polling stations (Seção Eleitoral). Polling districts have their limits defined according to geographical and demographic characteristics and are managed by electoral offices charged with taking care of electoral registers; Figures 12 and 13 in the appendix illustrate the distribution of mu-

\footnotetext{
${ }^{52}$ São Paulo is the wealthiest and most developed state in Brazil, with a population of over 44 million people and a territorial area close to $250,000 \mathrm{~km}^{2}$, equivalent to the area of the state of Michigan or to the United Kingdom.
} 
nicipalities within the state of São Paulo and the distribution of polling districts within the city of São Paulo. A polling station, on the other hand, consists of a very specific place in the polling district where each voter is designated to cast his or her vote, usually a specific room in a school or public service center. Buildings (polling places) with one of such polling stations tend, of course, to contain several ones. As such, polling stations represent a highly disaggregated level of observation. Figures 14 and 15 in appendix C provide a depiction of a polling place and a polling station, respectively, and Figure 10 below sums up the administrative hierarchy of electoral procedures in Brazil.

Figure 10: Administrative Hierarchy of Electoral Procedures in Brazil

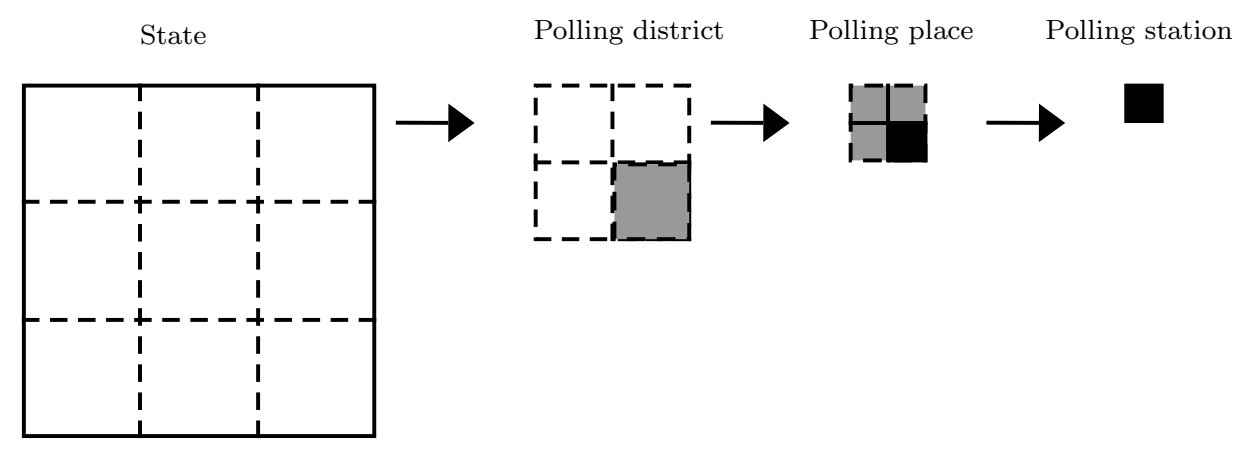

In addition, Brazilian legislation (Código Eleitoral, art. 117) dictates that polling stations have at most 400 voters in the states' capital cities or 300 voters in other cities, and at least 50 voters. ${ }^{53}$ Electoral laws also depict an effort of minimizing the distance between voters' places of residence and the polling stations to which they are assigned: at the time of electoral registration, voters are able to express their preferences over polling places (but not over specific polling stations) in the polling district of their residence, and they are also prohibited from choosing a polling place from a different polling district (Resolução TSE 21,538/2003, art. 9). ${ }^{54}$

\subsubsection{The Brazilian Public Educational System}

Public education in Brazil is free of charge to all Brazilian citizens and can be provided by municipalities, states or the federal government, depending on the level of education. The pre-college educational system is arranged into four levels: preschool (attended by 6 year-olds), primary school (attended by 7 to 10 year-olds), secondary school (attended

\footnotetext{
${ }^{53}$ However, the same legislation also authorizes the regional electoral courts to surpass these limits in exceptional circumstances.

${ }^{54}$ In private communications, a former employee of a regional electoral authority has stated that each voter is automatically allocated to the polling station with the lower number of voters among those stations in the polling place chosen by the voter.
} 
by 11 to 14 year-olds) and high school (attended by 15 to 17 year-olds). Since the main goal of this research is to investigate the influence teachers may present on students' voting patterns, the analysis is focused on the high school level, which comprises students qualified for voting. ${ }^{55}$

Even though São Paulo's public education system is one of the best in Brazil, it is far from the quality level presented in developed countries, which induces wealthier families to obtain education services from private schools. Nonetheless, the cost of education in private schools is extremely prohibitive for Brazilian standards; thus, around $85 \%$ of the students that achieve high school completion in Brazil do so in public schools. ${ }^{56}$

\subsubsection{Student and Teacher Placement in São Paulo's Public Schools}

The assignment of students to state high schools is regulated by state laws which fundamentally determine that students residing in a given school's area of influence ${ }^{57}$ receive priority in filling that school's class vacancies. The minimum distance criterion is naturally also the first to be considered in the placement of students that do not get to be enrolled in the school that is closest to their homes.

Teacher assignment to these schools, in its turn, occurs on the basis of tests conducted at the state level and specific to the school subject the applicant desires to teach. Applicants must achieve a pre-established minimum score in order to be considered apt for teaching, and those that do so are ranked according to their final score. ${ }^{58}$ A first group of top ranked candidates are then summoned for a session where they select their most preferred school among those with positions still available. School choice is made by one candidate at a time, and priority in that procedure follows the candidates' ranking (better ranked candidates get to pick their schools first). In the event that not all teacher positions are filled, new groups of lower ranked candidates are summoned for new school choice sessions

\footnotetext{
${ }^{55}$ High school education is usually provided by the state government, as directed by the Brazilian Constitution.

${ }^{56}$ Source: INEP. Available at <http://portal.inep.gov.br/rss $\backslash$ censo-escolar/-/asset $\backslash$ publisher/oV0H/ content/id/19910>.

${ }^{57}$ The area of influence of a given public (high) school is defined to be (roughly) the region to which the school consists of the closest public (high) school.

${ }^{58}$ Applicants must hold an academic degree called a license, obtained through the completion of specific college courses with a stronger emphasis on teaching methods and pedagogy than those leading to a bachelor's degree. Additional academic degrees like master's or doctorate degrees also contribute to the candidate's final score.
} 
until all positions have been filled or all ranked candidates have been summoned. From 2004 to 2008, more than 26,000 positions were opened for basic education (i.e. secondary and high school level) teachers in public schools managed by the state.

\subsection{Data and Estimation Framework}

The present analysis relies on several sources of data. In order to obtain information on teachers' political affiliation, individual level data - from the São Paulo State Department of Education - on public high school teachers in São Paulo's state-managed schools from 2008 to 2010 is combined with individual level information on politically affiliated voters for the same years, provided by the federal electoral authority (TSE). It is possible thus to identify, for each of those years, which of those teachers are affiliated, as well as the political party to which they are affiliated. In particular, a teacher is defined to be affiliated if it is possible to match his or her name to that of an affiliated voter who appears in the affiliated voter list for the corresponding year. Moreover, it is also used data - also provided by the TSE - on parties' electoral outcomes at the polling station level and on characteristics of voters allocated to each polling station.

The study of the relationship between the density of teachers affiliated to a given party and electoral outcomes for that party is made through the construction of measures of political affiliation at the level of regions consisting of intersections between polling districts and municipalities. ${ }^{59}$ This is done in order to gain more variation in the main independent variable, since there are 423 polling districts in the State of São Paulo as defined by the electoral authorities, whereas considering the intersection between polling districts and municipalities results in 790 units of observation. For brevity, such intersections will henceforth be referred to as polling districts, and originally-defined districts will be referred to as "TSE districts" should that need arise. This strategy also allows to have a more reasonable measure of the density of party-affiliated teachers as it imposes the restriction that students voting in a given municipality are most likely influenced by teachers in that municipality (but not by teachers in the same TSE district and in other municipalities). A deeper description of the relationship between the distributions of TSE districts and municipalities in the state of São Paulo is given in Tables 39 and 40 in appendix C.

\footnotetext{
${ }^{59}$ Each originally-defined district may either cover more than one municipality, have its area coincide with one, or be a smaller part of a municipality. Source: http://www.tse.jus.br/eleitor/zonas-eleitorais.
} 
The construction of measures of density of politically affiliated teachers would be a simple task if information on geographic limits of each of the TSE polling districts were available. Unfortunately, this is not the case. To circumvent this problem georeferencing algorithms are used to match each state school to its closest polling place in the same municipality. Then, each school is associated to the polling district corresponding to the matched polling place. Finally, for each district the proportion of teachers affiliated to each political party is computed.

Although the polling district is not the most disaggregated level at which it is possible to explore regional variation in the density of affiliated teachers, it is the most disaggregated level at which it is possible to credibly match that variation to the variation in electoral outcomes. For instance, an alternative approach would be to consider only those (statemanaged) schools that are used as polling places during elections and associate partyaffiliated teachers with electoral outcomes at the school level. This approach, however, imposes the strong restriction that students vote at the school where they study. As not all polling places are state-managed high schools, restricting the analysis to such schools would impose a selection problem that could compromise the interpretation of the estimated coefficients.

Before describing the empirical strategy, it is convenient to present some statistics related to the main independent variables, namely the share of high school teachers that are affiliated to each political party. The corresponding figures are displayed in Table 20.

The analysis is restricted to the four parties with the highest numbers of affiliated teachers at the state level: the Workers Party (PT), the Brazilian Social Democratic Party (PSDB), the Brazilian Labour Party (PTB) and the Brazilian Democratic Movement Party (PMDB). The PT is currently one of the most important parties in the Brazilian political scenario, governing at the federal level since 2003. The PSDB has been the PT's main opposition in the federal government and has been ruling the state of São Paulo since 1995, having PT as one of its main rivals at that state. The PTB has not shown great representation in the chamber of deputies and neither has it elected any governor in the last general election, but its relatively high number of affiliated teachers might be explained by its association with unions and labor organizations. In its turn, the PMDB is currently one of the biggest political parties in Brazil, being the second with more elected members in the chamber of deputies. 
Table 20: Share of Teachers Affiliated to Each Party

\begin{tabular}{lcc}
\hline \hline Political Party & 2008 & 2010 \\
\hline PT & $1.98 \%$ & $2.03 \%$ \\
PSDB & $0.99 \%$ & $0.93 \%$ \\
PTB & $0.67 \%$ & $0.65 \%$ \\
PMDB & $0.62 \%$ & $0.62 \%$ \\
PV & $0.43 \%$ & $0.45 \%$ \\
PSB & $0.37 \%$ & $0.35 \%$ \\
PPS & $0.37 \%$ & $0.32 \%$ \\
PP & $0.35 \%$ & $0.32 \%$ \\
DEM & $0.35 \%$ & $0.31 \%$ \\
PDT & $0.33 \%$ & $0.32 \%$ \\
PR & $0.32 \%$ & $0.31 \%$ \\
Others & $1.39 \%$ & $1.50 \%$ \\
\hline Number of High School Teachers & 94,277 & 98,594 \\
\hline \hline
\end{tabular}

Note: the shares of affiliated teachers are relative to the total of high school teachers in São Paulo's public schools.

The identification strategy resembles the approaches taken by Duflo (2001) and Card (1992) as variation in two dimensions that jointly determine the exposure of voters to affiliated teachers is exploited, in a difference-in-differences (DD) setup. As mentioned above, the first dimension, regarding "treatment intensity", consists of the share of teachers affiliated to a given party in each polling district. In turn, the second dimension exploited is related to voter demographic characteristics and amounts to the share of voters registered in each polling station that are likely - or intended - to be treated (i.e. to be high school students under the influence of affiliated teachers). If it is true that the presence of affiliated teachers has a significant effect on electoral outcomes (as a result of indoctrination in the classroom), this effect should be stronger in polling stations with higher shares of students. In order to identify those voters that are high school students, information on age and educational attainment reported by voters at the moment of electoral registration is used (information on whether voters are indeed enrolled at each electoral year is not available). It is important to note, however, that information on voter education is measured with some imprecision, since it is very unlikely to be updated after voter registration. ${ }^{60}$ For this reason, using solely the data on educational attainment to infer

\footnotetext{
${ }^{60}$ Voters are not required to keep this information updated with the electoral authorities. Rather, this information is usually updated only when the voter moves to a different city or a different district and decides to change his/her polling place.
} 
whether voters are enrolled in high school would possibly lead to a very imprecise measure of the actual proportion of enrolled voters, as middle-aged voters (for instance) could possibly still be suggested as currently enrolled in high school according to that information. On the other hand, unlike the data on education, information on voters' ages is based on voters' dates of birth and are constantly (automatically) updated by electoral authorities. The group of voters to be most likely affected by high school teachers is then defined to be that of voters aged between 16 and 17 and that are listed as having completed primary education but not high school (this subset of voters will also be referred to as the "target group"). ${ }^{61}$ In particular, since voters aged 16-17 have necessarily just registered, it is far less likely that the information on education listed in their registry is imprecise.

In essence, the approach employed in this chapter differs from the archetypical DD example in applied econometrics only in the sense that the variables representing treatment intensity and treatment status are both continuous rather than dummy variables. For each given political party, the following model is considered:

$$
\begin{gathered}
\text { vote_share }_{s, d}=\beta_{0}+\beta_{1} \text { teachers_party }{ }_{d} * \text { target_group }_{s, d}+\beta_{2} \text { target_group }_{s, d}+ \\
+\beta_{3} \text { teachers_party }{ }_{d}+\varepsilon_{s, d}
\end{gathered}
$$

where vote_share s,$d_{\text {is }}$ is the party's vote share at polling station $s$ in polling district $d$ concerning a given elective position, teachers_party $y_{d}$ is the percentage of high school teachers in public schools located in district $d$ who are affiliated to the given party, and target_group $_{s, d}$ is the share of voters registered in station $s$ (in polling district $d$ ) belonging to the target group. Summary statistics for these variables (as well as for other main variables presented throughout the chapter) are displayed in Tables 41-43 in the appendix C.

Naturally, a major concern in interpreting the estimates concerns the assignment of teachers and (student) voters to schools and polling stations. For instance, if teachers' decision processes regarding schools contemplated characteristics of the schools' neighborhoods that were correlated with electoral outcomes, the estimated coefficients would likely not be limited to capturing the hypothesized effects, but would rather be plagued by endogeneity issues. Thus, polling place fixed effects are introduced in the above model to particularly avoid such kinds of selection problems. In other words, it is assumed that

\footnotetext{
${ }^{61}$ Since not all voters in the target group are exposed to affiliated teachers in the corresponding polling district, the effect estimated is analogous to an intent-to-treat (ITT) effect.
} 
controlling for polling place fixed effects, teacher and voter assignment becomes (partially) uncorrelated to political characteristics of polling station cohorts, and that $\beta_{1}$ indeed captures the effect of the interaction between party-affiliated teachers and the segment of the electorate that is more likely to be politically influenced by them. It is important to note that introducing polling place fixed effects should not pose issues to the estimates as the average number of stations within a polling place in the sample is fairly high. ${ }^{62}$

Ultimately, then, the following model is estimated:

$$
\begin{aligned}
\text { vote_share }_{s, d}=\beta_{0} & +\beta_{1} \text { teachers_party }{ }_{d} * \text { target_group }_{s, d}+\beta_{2} \text { target_group }_{s, d}+ \\
& +\gamma_{b}+\varepsilon_{s, d}
\end{aligned}
$$

where $\gamma_{b}$ denotes a polling place fixed effect, which in particular absorbs all kinds of variation at the polling district level, such as that from teachers_partyd. Aside from separately estimating model (3.2) for each of the four parties listed above, the effect of interest is also estimated by pooling the observations for these parties. In that case, the model may be rewritten as:

$$
\begin{aligned}
\text { vote_share }_{p, s, d}=\beta_{0} & +\beta_{1} \text { teachers_party } \text { ted }_{\text {_t }} * \text { target_group }_{s, d}+\beta_{2} \text { target_group }_{s, d}+ \\
& +\gamma_{b, p}+\varepsilon_{s, d, p}
\end{aligned}
$$

where vote_share $e_{s, d, p}$ is the vote share obtained by party $p$ at polling station $s$ in polling district $d$, teachers_party $y_{d, p}$ is the percentage of high school teachers in public schools located in district $d$ who are affiliated to party $p$, and $\gamma_{b, p}$ denotes a party-polling place fixed effect.

\subsection{Main Results}

To illustrate the specifications considered above, this section begins by focusing on discussing the estimates obtained for the effect of teachers affiliated to the PT on that party's vote share at the 2010 presidential election. The corresponding results are presented in Table 21. Column (1) of that table presents the baseline specification of equation (3.1),

\footnotetext{
${ }^{62}$ Polling places had an average of 7.93 stations in 2008 and 8.27 stations in 2010 .
} 
while column (3) introduces polling place fixed effects, as described by model (3.2). Also, column (2) considers a slight modification of model (3.2) wherein we replace polling place fixed effects with district fixed effects.

Table 21: Effect of Teachers Affiliated to the PT on the Vote Share at the 2010 Presidential Election

\begin{tabular}{lccc}
\hline \hline Dep. Variable: vote_share $_{s, d}$ & $(1)$ & $(2)$ & $(3)$ \\
\hline \multicolumn{1}{c}{ teachers_party $*$ target_group,$d$} & -0.0058 & $0.0173^{* * *}$ & $0.0061^{*}$ \\
& $(0.0112)$ & $(0.0054)$ & $(0.0033)$ \\
target_group $_{s, d}$ & $0.2610^{* * *}$ & $0.0350^{* *}$ & $-0.0254^{* *}$ \\
& $(0.0348)$ & $(0.0141)$ & $(0.0108)$ \\
\multicolumn{1}{c}{ teachers_party } & $1.5683^{* * *}$ & & \\
& $(0.3719)$ & & \\
Observations & 75,591 & 75,591 & 75,591 \\
R-squared & 0.0480 & 0.6849 & 0.9263 \\
District FE & No & Yes & No \\
Polling Place FE & No & No & Yes \\
\hline \hline
\end{tabular}

Standard errors (in parenthesis) are robust to clustering at the polling district level. $*, * *$, and ${ }^{* * *}$ indicate significance at the $10 \%, 5 \%$ and $1 \%$ levels, respectively.

In particular, the coefficient $\beta_{3}$, associated with teachers_party , in column (1) shows, as possibly expected, that the assignment of affiliated teachers across districts is highly (and positively) correlated with the electoral performance of the corresponding party. This research, however, is primarily interested in the signal and magnitude of the coefficient $\beta_{1}$, associated with the interaction between the share of affiliated high school teachers and the share of voters in the target group. We first note that the omission of important variables would seriously compromise inferences based on the baseline specification (model (3.1)): while $\beta_{1}$ is estimated to be negative (but statistically insignificant) in column (1), the introduction of district and polling place fixed effects in columns (2) and (3), respectively, leads to positive (and significant) estimates of that coefficient. The corresponding estimate in column (3), for instance, indicates that once polling place specific characteristics are accounted for, the correlation between the density of teachers affiliated to the PT and that party's vote share in the 2010 presidential election is stronger in polling stations with higher shares of high school students aged between 16 and 17.

To better understand the magnitude of the estimate of $\beta_{1}$ presented in column (3), consider a polling station wherein $20 \%$ of the voters belong to the target group. Then, the corresponding estimate indicates that an increase by one percentage point (p.p.) in the 


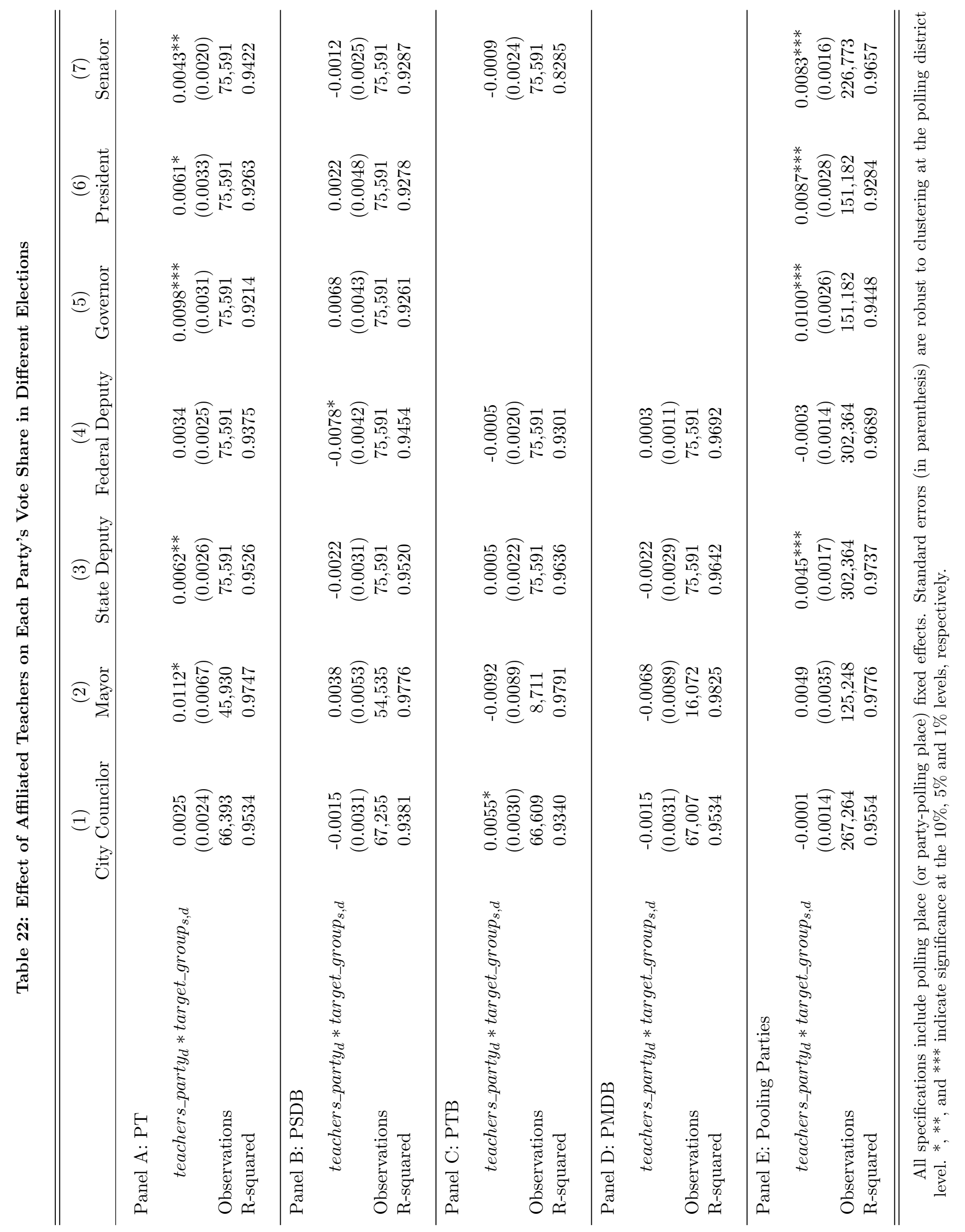


share of high school teachers affiliated to the PT (in the related polling district) is associated with an increase by 0.12 p.p. in the PT's vote share at that polling station in the 2010 presidential election as a result of their influence over voting-aged students. Were that polling station to contain 400 voters, for instance, such an effect would correspond to an average increase by approximately 0.5 in the number of votes received by the PT at that station. Such a magnitude may become even more relevant upon the observation that these estimates may be understood as intent-to-treat effects, since not all voters in the target group are guaranteed to be exposed to affiliated teachers. In that sense, the effect would be more important the smaller the share of voters actually exposed to affiliated teachers.

Next, the corresponding results for the four considered political parties and for each elective position disputed in 2008 and 2010 are presented. Such presentation, however, is restricted to the estimates obtained upon the estimation of models (3.2) and (3.3), wherein polling place fixed effects are included. Panels A through D of Table 22 present the results for the PT, the PSDB, the PTB, and the PMDB, whereas Panel E of that table shows the estimates obtained upon polling the observations of these parties. It is important to observe from the latter panel that, aside from the positions of city councilor and federal deputy (which are associated with negative and insignificant coefficients very close to zero), the presence of teachers affiliated to a "generic" party is associated with a positive effect on the vote share exhibited by such a party in all other elections. Moreover, this seems particularly true for elective positions filled under plurality rules - i.e. mayor, governor, president, and senator - for which the magnitude of the coefficients is higher (although the estimate corresponding to the position of mayor is statistically insignificant). The larger effect in Panel $\mathrm{E}$ is found for the position of governor, and indicates that in a polling station wherein $20 \%$ of the voters belong to the target group, a share of $1 \%$ of teachers affiliated to a party is responsible for 0.2 p.p. of the corresponding vote share as a result of the interaction with voting-aged high school students.

The contrast between the magnitude of the estimates obtained for elections under plurality rules and those for elections under a proportional representation system goes in line with the possibility that teachers opt to configure their propaganda in order to praise not their party as a whole, but rather the figure of specific candidates. Arguably, this kind of behavior would surely be harder in the occasions where multiple candidates from a single party could run for the same office, such as elections under proportional representation systems (but not those under plurality rules). 
However, as indicated by the inspection of Panels A-D, it should be noted that the results found by using the polling sample are possibly (entirely) driven by the corresponding results verified for the PT (Panel A), ${ }^{63}$ since the related estimates for the other three parties are usually statistically insignificant. This observation might suggest that the PT is somehow more capable or more effective than other parties in motivating their affiliated advocates towards engaging in partisan propaganda. Alternatively, it is possible that public manifestations of identification with some political ideologies are more easily conducted (and tolerated) than the defense of others. For instance, teachers affiliated to more rightist parties may be related to insignificant effects as a result of the tendency verified in Brazil since the late 1980s - known as "direita envergonhada", or embarrassed right - consisting of a certain reluctance or even shame by right-wing politicians as well as their voters to openly state their political positions and to be ideologically labeled as conservatives. ${ }^{64}$ As some authors have argued, this event is most likely reinforced by the link between rightist ideologies and the legacy of the Brazilian military dictatorship of 1964-85 (Pierucci (1987); Power \& Zucco (2012)). Hence, it is possible that the results are stronger for the PT as a consequence of that party being arguably the leftmost one among the four parties considered. ${ }^{65}$

\subsection{Further Exercises}

\subsubsection{Robustness Checks}

While the results presented in the last section are aligned with the hypothesis of partisan indoctrination in the classroom, they are also coherent with alternative explanations. In particular, the estimates reported in the previous sections may be driven by the influence that teachers might present on different but correlated audiences, under the condition of mere party-affiliated individuals outside the classroom environment - i.e. without employ-

\footnotetext{
${ }^{63}$ This event is most likely to be true for the elections of governor, president, and senator, which were not disputed by all four considered parties.

${ }^{64}$ See, for instance, Pierucci (1987), Rodrigues (1987), Power (2000). Power (2000) states in particular that a common political marketing strategy followed by candidates of conservative parties is to omit their party label from their campaign advertising.

${ }^{65}$ Power \& Zucco (2012) develop a continuous ideology index that places Brazilian political parties in a left-right political spectrum. Their measure is constructed from survey responses of almost eight hundred federal legislators from 1990 to 2009 and ranks parties in a scale from one to ten, with larger numbers being associated with right-wing ideologies. These authors argue that, for instance, more rightist positions in their scale are associated with a higher propensity to display more promarket economic preferences and to support the armed forces' right to intervene in order to guarantee internal order. Their index assumes the value of 3.08 for the PT, 5.56 for the PMDB, 5.65 for the PSDB, and 6.43 for the PTB.
} 
ing their teacher status to broaden their audience - and thus be affected by an omitted variable problem.

In order to explore whether this is the case, a similar exercise to that presented above, consisting of replacing the target group with a demographic group that is far less likely to interact with high school teachers (at least in a teacher-pupil relationship), is conducted. Namely, it is considered voters aged 16-17 that either had not initiated basic education, or that had already completed high school at the time of electoral registration (this group will henceforth be referred to as the "placebo group"). Specifically, models (3.2) and (3.3) are reestimated after replacing target_group $s_{s, d}$ with the share of voters in station $s$ (in polling district $d$ ) belonging to that placebo group (denoted placebo_group ${ }_{s, d}$ ).

The particular choice for voters aged 16-17 is made for two main reasons. First, as previously stated, considering such an age cohort allows to avoid imprecisions in voters' actual educational status at the time of election, as the corresponding voters are likely to have just registered for voting. Thus, voters aged 16-17 that are indicated by their electoral registers not to be enrolled in high school are expected to effectively be in that situation at the time of election. Also, should the previous estimates be driven by affiliated teachers influencing all voters aged 16-17 alike - i.e. regardless of being their high school students - one should expect to find estimates of a similar impact of those teachers on voting patterns of the placebo group. On the other hand, the absence of significant effects in that case could serve as further indication that the previously found evidence is indeed related to intraclassroom interactions between affiliated teachers and their pupils.

The corresponding results of that exercise are presented in Table 23. The estimates related to the PT and to the sample that pools the four considered parties (Panels A and E) are overall statistically insignificant, with the exception of the coefficients regarding the presidential election. Since these panels were the ones for which significant estimates were found in the main results, further confidence is gained on the hypothesis of political indoctrination in the classroom. The same event (of statistical insignificance) applies to the coefficients related to the PTB (Panel C) and to the PMDB (Panel D). On the other hand, some statistically significant estimates are found regarding the electoral influence of teachers affiliated to the PSDB on the placebo group. 


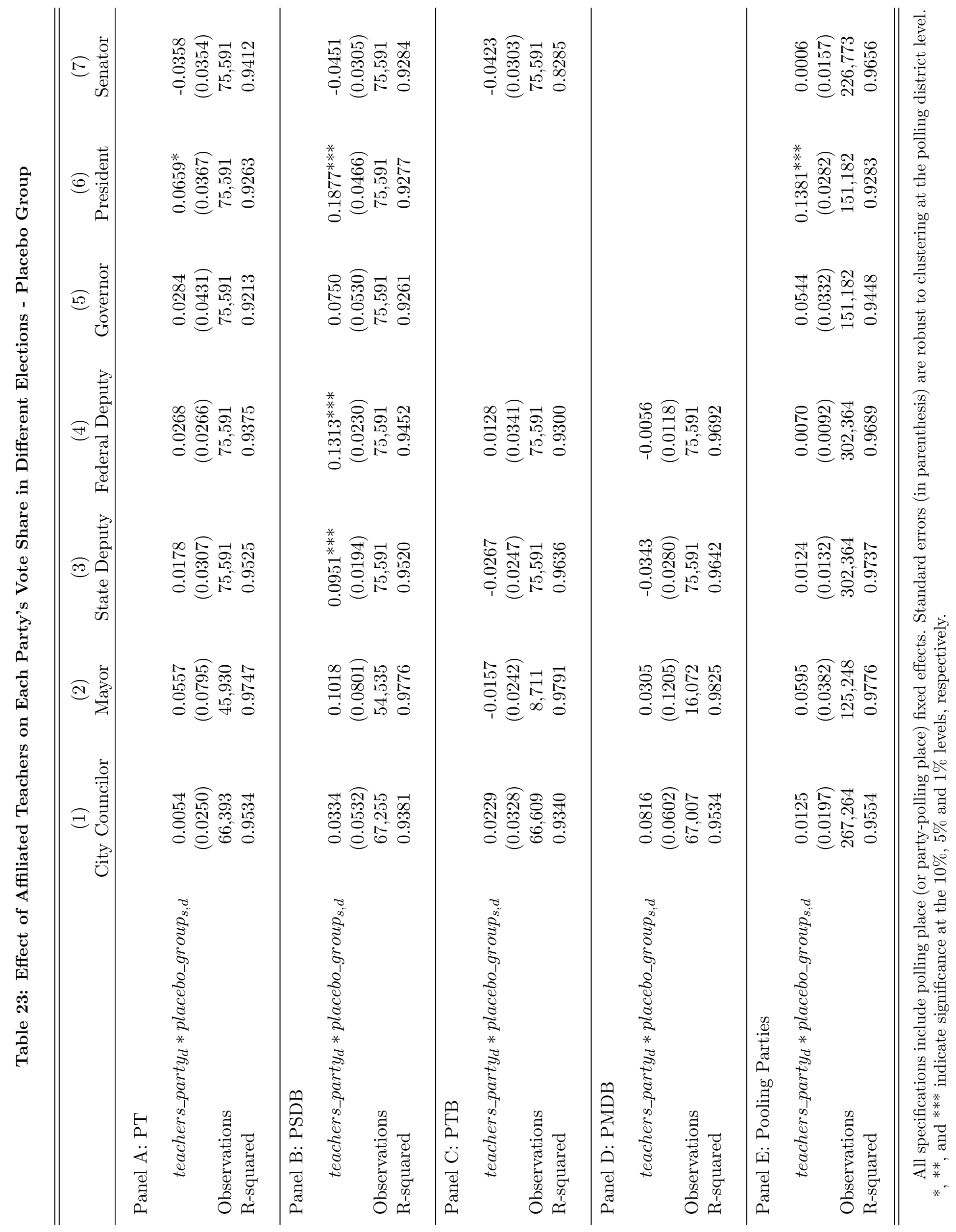




\subsubsection{Effects on Turnout}

Next, it is exploited whether affiliated teachers have an impact on their pupils' electoral turnout. In other words, this section tests whether the positive influence - evidenced in Section 3.4 - of such teachers on parties' vote shares specifically consists in convincing students that would otherwise not vote. In particular, confronting that hypothesis with the alternative possibility that the effect of affiliated teachers on vote shares is actually driven by shifting students' political preferences from one party to another could lead to a better understanding of the effectiveness of political indoctrination by teachers as well as of political participation among the young, for instance.

For each of the four considered parties and for each election year, the following model is estimated:

$$
\begin{aligned}
\text { turnout }_{s, d}=\beta_{0} & +\beta_{1} \text { teachers_party } \\
& * \text { target_group }_{s, d}+\beta_{2} \text { target_group }_{s, d}+ \\
& +\varepsilon_{s, d}
\end{aligned}
$$

where turnout $_{s, d}$ denotes the turnout rate (ranging from 0 to 100) at polling station $s$ in polling district $d$. Unlike the preceding regressions, however, in estimating model (3.4) observations on all polling stations (at the given election year) are used rather than only those on stations in administrative units (municipalities) wherein the given party effectively ran for election (and had a well defined vote share). As before, model (3.4) is also estimated by pooling observations on the four parties after replacing polling place fixed effects with party-polling place fixed effects.

The corresponding results are presented in Table 24. Panel A of that table presents estimates regarding the effect on turnout at the 2008 local elections, whereas Panel B considers turnout at the 2010 general elections. First, it is possible to observe from Panel A that the density of teachers affiliated to the PSDB or to the PTB has a positive effect (as a result of their interactions with voting-aged students) on turnout at local elections. For instance, the coefficient associated with the PTB indicates that, regarding a polling station wherein $20 \%$ of the voters belong to the target group, a share of 1 p.p. of teachers affiliated to that party is responsible for almost 0.3 p.p. of the turnout rate at such a polling station in 2008. However, as previously shown in Table 22, such an effect on turnout was not (significantly) translated into positive effects on these two parties' vote 
shares in the corresponding elections. Similarly, despite having presented a significant impact on vote shares, teacher affiliation to the PT is not suggested to influence student turnout. Thus, for that party it may be the case that affiliated teachers are actually able to change the political leanings of students that would vote for another party. On the other hand, the estimates associated with turnout at the 2010 general elections are overall statistically insignificant. An exception is made for the coefficient related to the PMDB, which is negative and significant at the $10 \%$ level. We conjecture, though, that the significance of that coefficient may be related to the fact that there was no candidate running under the PMDB for the positions of governor, senator, or president in 2010.

Table 24: Effect of Affiliated Teachers on Voter Turnout

\begin{tabular}{lccccc}
\hline \hline & $(1)$ & $(2)$ & $(3)$ & $(4)$ & $(5)$ \\
& PT & PSDB & PTB & PMDB & Pooling \\
\hline Panel A: 2008 Local Elections & & & & & \\
$\quad$ teachers_party $*$ target_group,$d$ & -0.0036 & $0.0087^{* *}$ & $0.0144^{* *}$ & 0.0002 & $0.0033^{*}$ \\
& $(0.0038)$ & $(0.0036)$ & $(0.0058)$ & $(0.0048)$ & $(0.0019)$ \\
Observations & 67,355 & 67,355 & 67,355 & 67,355 & 269,420 \\
R-squared & 0.6866 & 0.6867 & 0.6867 & 0.6866 & 0.6866 \\
& & & & & \\
\hline Panel B: 2010 General Elections & & & & & \\
$\quad$ teachers_party $*$ target_group $p_{s, d}$ & -0.0059 & -0.0060 & -0.0100 & $-0.0092^{*}$ & $-0.0065^{* *}$ \\
& $(0.0052)$ & $(0.0062)$ & $(0.0079)$ & $(0.0050)$ & $(0.0028)$ \\
Observations & 75,591 & 75,591 & 75,591 & 75,591 & 302,364 \\
R-squared & 0.6608 & 0.6608 & 0.6608 & 0.6608 & 0.6608 \\
\hline \hline
\end{tabular}

All specifications include polling place (or party-polling place) fixed effects. Standard errors (in parenthesis) are robust to clustering at the polling district level. ${ }^{*}, * *$, and $* * *$ indicate significance at the $10 \%, 5 \%$ and $1 \%$ levels, respectively.

\subsection{Conclusion}

This paper investigated the influence that politically active teachers may present in the electoral process through shaping their students' voting behavior by means of partisan propaganda in the classroom environment. This analysis is achieved by exploiting very rich databases on public high school teachers and on party-affiliated voters - through which it was possible to identify high school teachers' political affiliations - and by considering the relationship between the density of affiliated teachers and electoral outcomes for the corresponding party in a given region. 
To overcome the matter of selection in the assignment of teachers to schools and of voters to polling places (which would likely bias the estimates), it was exploited variation in the intensity of the hypothesized effect according to characteristics of the electorate at a level (polling stations) into which, arguably, neither teachers nor voters are able to select themselves.

Evidence consistent with the hypothesis of political indoctrination in the classroom was found. Moreover, the effect of the presence of party-affiliated teachers on a party's vote share seems to be more pronounced for elections based on plurality voting systems. However, it was found evidence that such an effect is apparently driven by teachers affiliated to the Workers' Party. In addition, such teachers do not appear to have an effect on electoral turnout by their students, so their impact on vote shares is suggested to take place through altering the political leanings of students that would turn out to vote regardless of their interference.

The findings indicating party-affiliated teachers may play such a role raise very important questions, especially regarding what kind of teaching is ultimately being performed in their classes, and whether the suggested diversion from curriculum content standards is deleterious to educational outcomes of their students. In this sense, it would be worthwhile to also investigate whether teachers of certain subjects have relatively more leeway to define their courses' contents (and their ways of presenting them), and thus a greater ability to influence electoral outcomes. Moreover, another interesting topic concerns the reasons why teachers would be engaging in that kind of behavior, and particularly whether party-affiliated teachers are being paid to politically influence their pupils. Such questions are left as agenda for future research. 


\section{BIBLIOGRAPHY}

ACEMOGLU, D.; JOHNSON, S.; ROBINSON, J. A. Reversal of fortune: Geography and institutions in the making of the modern world income distribution. The Quarterly Journal of Economics, v. 117, n. 4, p. 1231-1294, November 2002. Disponível em: < http: //ideas.repec.org/a/tpr/qjecon/v117y2002i4p1231-1294.html>.

ACEMOGLU, D.; ROBINSON, J. A. Persistence of power, elites, and institutions. American Economic Review, v. 98, n. 1, p. 267-93, March 2008.

ACEMOGLU, D.; ROBInSON, J. A.; SANTOS, R. J. The monopoly of violence: Evidence from colombia. Journal of the European Economic Association, Blackwell Publishing Inc, v. 11, p. 5-44, 2013. ISSN 1542-4774. Disponível em: <http://dx.doi.org/10. $1111 / \mathrm{j} .1542-4774.2012 .01099 . \mathrm{x}>$.

ALESINA, A.; TABELLINI, G. Bureaucrats or politicians? part i: A single policy task. American Economic Review, v. 97, n. 1, p. 169-179, 2007. Disponível em: <http://www. aeaweb.org/articles.php?doi=10.1257/aer.97.1.169>.

ALMEIDA, M. L. de. Comunicação de massa no Brasil. [S.l.]: Edições Júpiter;[distribuidor: Cultura Representações], 1971.

ARAUJO, M. C. et al. Local inequality and project choice: Theory and evidence from ecuador. Journal of Public Economics, Elsevier, v. 92, n. 5, p. 1022-1046, 2008.

ARULAMPALAM, W. et al. Electoral goals and center-state transfers: A theoretical model and empirical evidence from india. Journal of Development Economics, Elsevier, v. 88, n. 1, p. 103-119, 2009.

BARDHAN, P.; MOOKHERJEE, D. Capture and governance at local and national levels. American Economic Review, JSTOR, p. 135-139, 2000.

BESLEY, T.; BURGESS, R. The political economy of government responsiveness: Theory and evidence from india. The Quarterly Journal of Economics, v. 117, n. 4, p. 1415-1451, 2002. Disponível em: <http://qje.oxfordjournals.org/content/117/4/1415.abstract>.

BESLEY, T.; COATE, S. Elected versus appointed regulators: Theory and evidence. Journal of the European Economic Association, Blackwell Publishing Ltd, v. 1, n. 5, p. 1176-1206, 2003. ISSN 1542-4774. Disponível em: <http://dx.doi.org/10.1162/ $154247603770383424>$.

BESLEY, T.; PRAT, A. Handcuffs for the grabbing hand? the role of the media in political accountability. American Economic Review, Citeseer, v. 96, n. 3, p. 720-736, 2006.

BO, E. D.; TELLA, R. D. Capture by threat. Journal of Political Economy, v. 111, n. 5, p. 1123-1152, October 2003. Disponível em: < http://ideas.repec.org/a/ucp/jpolec/ v111y2003i5p1123-1152.html>.

BROLLO, F.; NANNICINI, T. Tying your enemy's hands in close races: The politics of federal transfers in brazil. American Political Science Review, Cambridge Univ Press, v. 106, n. 04, p. 742-761, 2012. 
CARD, D. Using regional variation in wages to measure the effects of the federal minimum wage. Industrial and Labor Relations Review, v. 46, n. 1, p. 22-37, 1992.

CASTRO, A. B. d.; SOUZA, F. P. d. A economia brasileira em marcha forçada. 3. ed. [S.1.]: Paz e Terra, 2004.

CASTRO, L. B. d. Esperança, frustração e aprendizado: a história da nova república. In: GIAMBIAGI, F.; VILlELA, A. (Ed.). Economia Brasileira Contemporânea: 1945-2004. [S.1.]: Elsevier, 2005.

CHONG, A.; FERRARA, E. L. Television and divorce: Evidence from brazilian novelas. Journal of the European Economic Association, Wiley Online Library, v. 7, n. 2-3, p. 458-468, 2009.

CORRALES, J. Political obstacles to expanding and improving schooling in developing countries. Educating all children: A global agenda, MIT Press, p. 231-299, 2006.

DEE, T. S. Are there civic returns to education? Journal of Public Economics, Elsevier, v. 88, n. 9, p. 1697-1720, 2004.

DELlaVIGNA, S.; KAPLAN, E. The Fox News effect: Media bias and voting. [S.l.], 2006.

DJANKOV, S. et al. Who owns the media? [S.l.], 2001.

DUFLO, E. Schooling and labor market consequences of school construction in indonesia: Evidence from an unusual policy experiment. American Economic Review, v. 91, n. 4, p. 795, 2001.

DYCK, A.; ZINGALES, L. The right to tell: the role of the media in development, chap. The corporate governance role of the media. The World Bank, 2002.

EBERTS, R. W.; STONE, J. A. Teacher unions and the productivity of public schools. Industrial and Labor Relations Review, Sage Publications, Inc., v. 40, n. 3, p. pp. 354-363, 1987. ISSN 00197939. Disponível em: <http://www.jstor.org/stable/2523492>.

FARIA, V.; POTTER, J. Television, Telenovelas, and Fertility Change in North-East Brazil" a Richard Leete,(ed.) Dynamic of Values in Fertility Change, Nueva York: IUSSP. [S.l.]: Oxford University Press, 1999.

FERRARA, E. L.; CHONG, A.; DURYEA, S. Soap operas and fertility: Evidence from brazil. American Economic Journal: Applied Economics, JSTOR, p. 1-31, 2012.

FINAN, F. Political patronage and local development: A brazilian case study. ARE, UC Berkeley, 2004.

GALASSO, E.; RAVALLION, M. Decentralized targeting of an antipoverty program. Journal of Public economics, Elsevier, v. 89, n. 4, p. 705-727, 2005.

GENTZKOW, M. Television and voter turnout. The Quarterly Journal of Economics, JSTOR, p. 931-972, 2006.

GENTZKOW, M.; GLAESER, E. L.; GOLDIN, C. The rise of the fourth estate. how newspapers became informative and why it mattered. In: Corruption and Reform: Lessons from America's Economic History. [S.l.]: University of Chicago Press, 2006. p. 187-230. 
GEORGE, L.; WALDFOGEL, J. Does the new york times spread ignorance and apathy? American Economic Review, forthcoming, 2002.

GERBER, A.; KARLAN, D. S.; BERGAN, D. Does the media matter? a field experiment measuring the effect of newspapers on voting behavior and political opinions. A Field Experiment Measuring the Effect of Newspapers on Voting Behavior and Political Opinions (February 15, 2006). Yale Economic Applications and Policy Discussion Paper, n. 12, 2006.

GERBER, A. S.; GREEN, D. P. The effects of canvassing, telephone calls, and direct mail on voter turnout: A field experiment. American Political Science Review, Cambridge Univ Press, v. 94, n. 03, p. 653-663, 2000.

GINSBURG, M. B. et al. Educators/politics. Comparative education review, JSTOR, p. 417-445, 1992.

GROSECLOSE, T.; MILYO, J. A measure of media bias. The Quarterly Journal of Economics, JSTOR, p. 1191-1237, 2005.

HAHN, C. Becoming political: Comparative perspectives on citizenship education. [S.l.]: Suny Press, 1998.

HAMILTON, J. All the news that's fit to sell: How the market transforms information into news. [S.l.]: Princeton University Press, 2004.

HANUSHEK, E. Publicly provided education. in: Auerbach, a., feldstein, m. (eds.), the handbook of public economics, volume 4, elsevier, amsterdam. p. 2045-2141, 2002.

HERMAN, E. S.; CHOMSKY, N. Manufacturing consent: The political economy of the mass media. [S.l.]: Random House, 2010.

HERMAN, J. Reformas, endividamento e o "milagre" econômico. In: GIAMBIAGI, F.; VILlELA, A. (Ed.). Economia Brasileira Contemporânea: 1945-2004. [S.l.]: Elsevier, 2005 .

HILLYGUS, D. S. The missing link: Exploring the relationship between higher education and political engagement. Political Behavior, Springer, v. 27, n. 1, p. 25-47, 2005.

HOROWITZ, D. The professors: The 101 most dangerous academics in America. [S.l.]: Regnery Publishing, 2006.

HOXBY, C. M. How teachers' unions affect education production. The Quarterly Journal of Economics, v. 111, n. 3, p. 671-718, 1996. Disponível em: <http://qje.oxfordjournals. org/content/111/3/671.abstract>.

IMBENS, G. W.; LEMIEUX, T. Regression discontinuity designs: A guide to practice. Journal of Econometrics, v. 142, n. 2, p. 615 - 635, 2008. ISSN 0304-4076. The regression discontinuity design: Theory and applications. Disponível em: <http: //www.sciencedirect.com/science/article/pii/S0304407607001091>.

KAM, C. D.; PALMER, C. L. Reconsidering the effects of education on political participation. The Journal of Politics, Cambridge Univ Press, v. 70, n. 03, p. 612-631, 2008. 
KAM, C. D.; PALMER, C. L. Reconsidering the effects of education on political participation. The Journal of Politics, v. 70, p. 612-631, 7 2008. ISSN 1468-2508.

KEEFER, P. Clientelism, credibility, and the policy choices of young democracies. American Journal of Political Science, Blackwell Publishing Inc, v. 51, n. 4, p. 804-821, 2007. ISSN 1540-5907. Disponível em: <http://dx.doi.org/10.1111/j.1540-5907.2007.00282.x>.

KEELE, L.; TITIUNIK, R.; ZUBIZARRETA, J. R. Enhancing a geographic regression discontinuity design through matching to estimate the effect of ballot initiatives on voter turnout. Journal of the Royal Statistical Society: Series A (Statistics in Society), v. 178, n. 1, p. 223-239, 2015. ISSN 1467-985X. Disponível em: < http://dx.doi.org/10.1111/rssa. $12056>$.

KHEMANI, S. Does delegation of fiscal policy to an independent agency make a difference? evidence from intergovernmental transfers in india. Journal of Development Economics, Elsevier, v. 82, n. 2, p. 464-484, 2007.

KITSCHELT, H.; WILKINSON, S. I. Patrons, clients and policies: Patterns of democratic accountability and political competition. [S.l.]: Cambridge University Press, 2007.

LARREGUY, H. Monitoring political brokers: Evidence from clientelistic networks in méxico. 2013.

LARREGUY, H.; MARSHALL, J.; SNYDER, J. M. Political advertising in consolidating democracies: Locally dominant parties and the equalization of media access in mexico. APSA 2014 Annual Meeting Paper, 2014. Disponível em: < http://ssrn.com/abstract= $2454757>$.

LEãO, S. Essays on Banking. Tese (Doutorado) — Pontifícia Universidade Católica do Rio de Janeiro, 2011.

LIMA, V. A. d. Comunicação e política. São Paulo: Hacker Editores, 2001.

LIMONGI, F.; CHEIDUB, J. A.; FIGUEIREDO, A. C. Participação política no brasil. In: ARRETCHE, M. (Ed.). Trajetórias das Desigualdades: Como o Brasil Mudou nos Últimos Cinquenta Anos. [S.l.]: Editora Unesp, 2015.

MAINWARING, S. Rethinking party systems in the third wave of democratization: the case of Brazil. [S.l.]: Stanford University Press, 1999.

MARTINEZ-BRAVO, M. The role of local officials in new democracies: Evidence from indonesia. American Economic Review, v. 104, n. 4, p. 1244-87, 2014. Disponível em: <http://www.aeaweb.org/articles.php?doi=10.1257/aer.104.4.1244>.

MARTINEZ-BRAVO, M.; MUKHERJEE, P. An empirical investigation of the legacies of non-democratic regimes: The case of soeharto's mayors in indonesia. Working paper, 2015.

MARTINEZ-BRAVO, M. et al. Do local elections in non-democracies increase accountability? Evidence from rural China. [S.l.], 2011.

MATTOS, S. A. S. Domestic and foreign advertising in television and mass media growth: a case study of Brazil. Tese (Doutorado) — University of Texas at Austin, 1982. 
MCMILlAN, J.; ZOIDO, P. How to subvert democracy: Montesinos in peru. CEPR Discussion Paper, 2004.

MIGUEL, L. F. Meios de comunicação de massa e política no brasil. Diálogos latinoamericanos, Aarhus Universitet, v. 3, p. 43-70, 2001.

MILLIGAN, K.; MORETTI, E.; OREOPOULOS, P. Does education improve citizenship? evidence from the united states and the united kingdom. Journal of Public Economics, Elsevier, v. 88, n. 9, p. 1667-1695, 2004.

MOE, T. M. Special Interest: Teachers Unions and America's Public Schools. [S.l.]: Brookings Institution Press, 2011. ISBN 0815722729.

MYERS, J. P. Citizenship education practices of politically active teachers in porto alegre, brazil and toronto, canada. Comparative Education Review, JSTOR, v. 51, n. 1, p. 1-24, 2007.

NICOLAU, J. Eleições No Brasi: do Império aos Dias Atuais. [S.l.]: Zahar, 2012.

NIE, N.; JUNN, J.; STEHLIK-BARRY, K. Education and citizenship in America. [S.1.]: Chicago: Cambridge University Press, 1996.

PERSSON, M. Testing the relationship between education and political participation using the 1970 british cohort study. Political Behavior, Springer, p. 1-21, 2014.

PIERUCCI, A. F. As bases da nova direita. Novos Estudos Cebrap, v. 19, p. 26-45, 1987.

PORTO, M. P. Telenovelas and national identity in brazil. In: IX International Congress of the Brazilian Studies Association (BRASA), New Orleans. [S.l.: s.n.], 2008.

POWER, T. J. The Political Right in Postauthoritarian Brazil: Elites, Institutions, and Democratization. [S.l.]: University Park: Pennsylvania State University Press, 2000.

POWER, T. J.; ZUCCO, C. Elite preferences in a consolidating democracy: the brazilian legislative surveys, 1990-2009. Latin American Politics and Society, Wiley Online Library, v. 54, n. 4, p. 1-27, 2012.

PRAT, A.; STRÖMBERG, D. The political economy of mass media. CEPR Discussion Paper No. DP8246, 2011.

PRIOR, M. Post-broadcast democracy: How media choice increases inequality in political involvement and polarizes elections. [S.l.]: Cambridge University Press, 2007.

PUGLISI, R. Being the new york times: the political behaviour of a newspaper. The $B E$ Journal of Economic Analysis $\&$ Policy, v. 11, n. 1, 2011.

ROCKOFF, J. E. The impact of individual teachers on student achievement: Evidence from panel data. American Economic Review, JSTOR, p. 247-252, 2004.

RODRIGUES, L. M. Quem é quem na Constituinte: uma análise sócio-política dos partidos e deputados. [S.l.]: OESP, 1987.

SCHAFFER, F. C. Elections for sale: the causes and consequences of vote buying. [S.1.]: Lynne Rienner Publishers Londres, 2007. 
SCHUGURENSKY, D.; MYERS, J. A framework to explore lifelong learning: The case of the civic education of civics teachers. International Journal of Lifelong Education, Taylor \& Francis, v. 22, n. 4, p. 325-352, 2003.

SINGER, P. O processo econômico. In: DANIEL, A. R. (Ed.). Modernização, Ditadura e Democracia: 1964-2012-. 1. ed. [S.1.]: Objetiva, 2014. v. 5, p. 320.

SOLÉ-OLLÉ, A.; SORRIBAS-NAVARRO, P. The effects of partisan alignment on the allocation of intergovernmental transfers. differences-in-differences estimates for spain. Journal of Public Economics, Elsevier, v. 92, n. 12, p. 2302-2319, 2008.

SOLIS, A. Does higher education cause political participation? Evidence from a regression discontinuity design. [S.l.], 2013.

STRAUBHAAR, J. D. The reflection of the brazilian political opening in the telenovela [soap opera], 1974-1985. Studies in Latin American Popular Culture, STUDIES LATIN AMER POPULAR CULTURE C/O CHARLES TATUM, CO-EDITOR, UNIV ARIZONA, FACULTY HUMANITIES, TUCSON, AZ 85721, v. 7, p. 59-76, 1988.

STRAUBHAAR, J. D. Television and video in the transition from military to civilian rule in brazil. Latin American Research Review, JSTOR, p. 140-154, 1989.

STRÖMBERG, D. Radio's impact on public spending. The Quarterly Journal of Economics, JSTOR, p. 189-221, 2004.

TELLA, R. D.; FRANCESCHELLI, I. Government advertising and media coverage of corruption scandals. [S.l.], 2009.

WESTHEIMER, J.; KAHNE, J. What kind of citizen? political choices and educational goals. Encounters on education, v. 4, 2008.

WOLFInGER, R. E.; ROSENSTONE, S. J. Who votes? [S.l.]: New Haven: Yale University Press, 1980. 


\section{Appendix A}

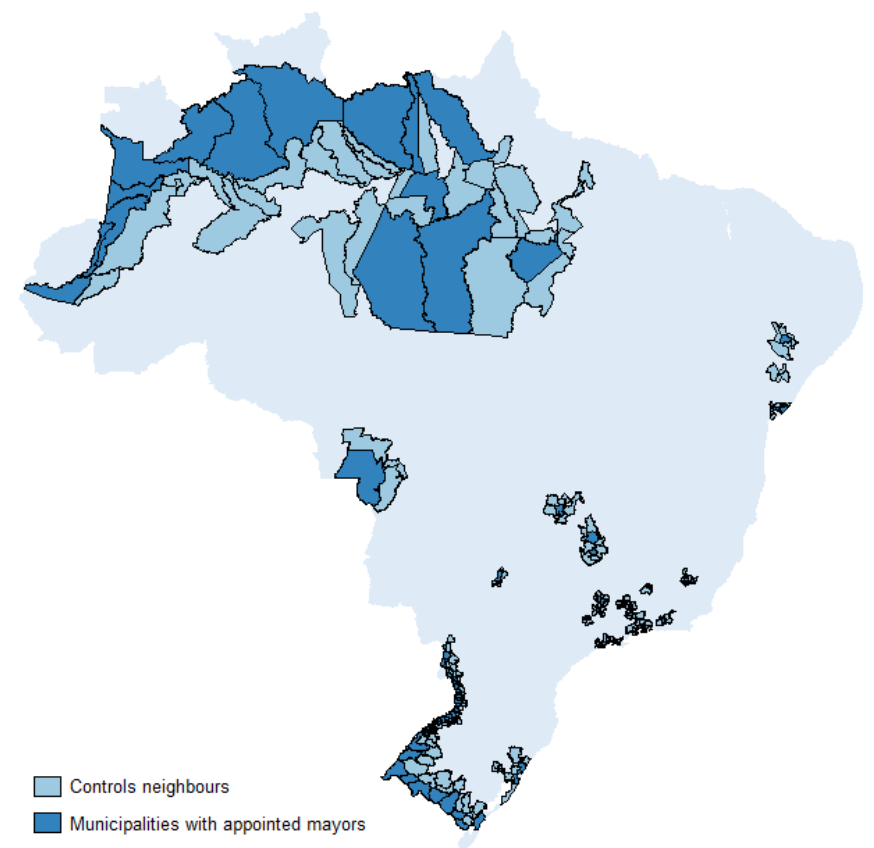

Figure 11: Municipalities with appointed mayors in the sample and neighbors used as the control group (without matching)

Table 25: Balance check of the baseline characteristics between municipalities with appointed mayors and the control group (without matching)

(1)

Mun. with

appointed mayors
$(2)$

Control municipalities p-value

\begin{tabular}{lccc}
\hline Inequality (Theil index) & 38.04 & 36.54 & 0.28 \\
Share of pop. living in urban areas & 32.69 & 31.34 & 0.62 \\
$\log$ (population) & 9.98 & 9.55 & 0.00 \\
Population density (inhabitants/km 2 ) & 65.24 & 117.33 & 0.49 \\
Share of illiteracy & 29.65 & 33.81 & 0.03 \\
Average years of schooling & 2.15 & 1.84 & 0.01 \\
Income per capita (in minimum wages) & 0.49 & 0.45 & 0.32 \\
Log(number of households) & 8.27 & 7.86 & 0.00 \\
Life expectancy & 54.07 & 53.04 & 0.05 \\
Share of pop. occupied & 32.70 & 31.39 & 0.06 \\
Share of households with sanitation & 8.91 & 7.87 & 0.59 \\
Share of households with piped water & 22.98 & 21.37 & 0.58 \\
Share of households with electricity & 31.48 & 31.38 & 0.98 \\
Share of pop. living in poverty & 73.70 & 76.16 & 0.29 \\
\hline Number of municipalities & 81 & 197 & \\
\hline
\end{tabular}


Table 26: Effect on the Theil index (without matching)

Dependent variable: Theil index in year $t$; covariates measured in $t=1970$

\begin{tabular}{|c|c|c|c|c|}
\hline & \multicolumn{2}{|c|}{$\mathrm{t}=1980$} & \multicolumn{2}{|c|}{$\mathrm{t}=1991$} \\
\hline & $(1)$ & $(2)$ & $(3)$ & $(4)$ \\
\hline \multirow[t]{2}{*}{ Appointed mayor } & $3.5216^{* *}$ & 2.2897 & $5.6973^{* * *}$ & $3.7464^{* *}$ \\
\hline & $(1.5104)$ & $(1.4551)$ & $(1.7448)$ & $(1.6491)$ \\
\hline \multirow[t]{2}{*}{ Inequality (Theil index) } & $0.5810^{* * *}$ & $0.5965^{* * *}$ & $0.2439^{* * *}$ & $0.3033^{* * *}$ \\
\hline & $(0.0695)$ & $(0.0959)$ & $(0.0809)$ & $(0.1079)$ \\
\hline \multirow[t]{2}{*}{ Share of pop. living in urban areas } & & -0.0042 & & -0.0361 \\
\hline & & $(0.0606)$ & & $(0.0780)$ \\
\hline \multirow[t]{2}{*}{ Log(population) } & & -10.9123 & & $23.4167^{* *}$ \\
\hline & & $(11.0938)$ & & $(11.2136)$ \\
\hline \multirow[t]{2}{*}{ Population density } & & -0.0016 & & -0.0009 \\
\hline & & $(0.0010)$ & & $(0.0007)$ \\
\hline \multirow[t]{2}{*}{ Share of illiteracy } & & -0.1758 & & 0.1183 \\
\hline & & $(0.1198)$ & & $(0.1278)$ \\
\hline \multirow[t]{2}{*}{ Average years of schooling } & & -1.9276 & & $4.5600^{*}$ \\
\hline & & $(2.4069)$ & & $(2.3955)$ \\
\hline \multirow[t]{2}{*}{ Income per capita (in minimum wages) } & & 1.1827 & & 9.1653 \\
\hline & & $(6.5794)$ & & $(5.9550)$ \\
\hline \multirow[t]{2}{*}{ Log(number of households) } & & 12.2541 & & $-22.2124^{* *}$ \\
\hline & & $(11.1329)$ & & $(11.1984)$ \\
\hline \multirow[t]{2}{*}{ Life expectancy } & & $0.7802^{* * *}$ & & $0.8159^{* * *}$ \\
\hline & & $(0.2714)$ & & $(0.2785)$ \\
\hline \multirow[t]{2}{*}{ Share of pop. occupied } & & -21.4805 & & $-35.8878^{* *}$ \\
\hline & & $(14.9620)$ & & $(17.4987)$ \\
\hline \multirow[t]{2}{*}{ Share of households with sanitation } & & 0.0879 & & 0.0425 \\
\hline & & $(0.0691)$ & & $(0.0785)$ \\
\hline \multirow[t]{2}{*}{ Share of households with piped water } & & 0.0049 & & -0.0330 \\
\hline & & $(0.0707)$ & & $(0.0831)$ \\
\hline \multirow[t]{2}{*}{ Share of households with electricity } & & $-0.1956^{* *}$ & & -0.1042 \\
\hline & & $(0.0984)$ & & $(0.0870)$ \\
\hline \multirow[t]{2}{*}{ Share of pop. in poverty } & & 0.0166 & & $0.2216^{*}$ \\
\hline & & $(0.1663)$ & & $(0.1254)$ \\
\hline Observations & 278 & 278 & 278 & 278 \\
\hline R-squared & 0.22 & 0.35 & 0.07 & 0.26 \\
\hline
\end{tabular}


Table 27: Effect on income distribution in 1991 (without matching)

\begin{tabular}{|c|c|c|c|c|c|}
\hline & $\begin{array}{c}(1) \\
\text { Share of } \\
\text { income } \\
\text { earned by } \\
\text { the } 20 \% \\
\text { poorest }\end{array}$ & $\begin{array}{c}(2) \\
\text { Share of } \\
\text { income } \\
\text { earned by } \\
\text { the } 40 \% \\
\text { poorest }\end{array}$ & $\begin{array}{c}(3) \\
\text { Share of } \\
\text { income } \\
\text { earned by } \\
\text { the } 60 \% \\
\text { poorest }\end{array}$ & $\begin{array}{c}(4) \\
\text { Share of } \\
\text { income } \\
\text { earned by } \\
\text { the } 20 \% \\
\text { richest }\end{array}$ & $\begin{array}{c}(5) \\
\text { Share of } \\
\text { income } \\
\text { earned by } \\
\text { the } 10 \% \\
\text { richest }\end{array}$ \\
\hline Appointed mayor & $\begin{array}{c}-0.3058^{* *} \\
(0.1304)\end{array}$ & $\begin{array}{c}-0.7845^{* * *} \\
(0.2789)\end{array}$ & $\begin{array}{c}-1.3161^{* * *} \\
(0.4677)\end{array}$ & $\begin{array}{c}1.8190^{* * *} \\
(0.6794)\end{array}$ & $\begin{array}{l}1.9555^{* *} \\
(0.7714)\end{array}$ \\
\hline Inequality (Theil index) & $\begin{array}{l}-0.0135^{*} \\
(0.0079)\end{array}$ & $\begin{array}{c}-0.0465^{* *} \\
(0.0188)\end{array}$ & $\begin{array}{c}-0.0891^{* * *} \\
(0.0331)\end{array}$ & $\begin{array}{c}0.1495^{* * *} \\
(0.0475)\end{array}$ & $\begin{array}{c}0.1576^{* * *} \\
(0.0520)\end{array}$ \\
\hline Share of pop. living in urban areas & $\begin{array}{c}0.0021 \\
(0.0058)\end{array}$ & $\begin{array}{c}0.0049 \\
(0.0144)\end{array}$ & $\begin{array}{c}0.0011 \\
(0.0254)\end{array}$ & $\begin{array}{l}-0.0032 \\
(0.0364)\end{array}$ & $\begin{array}{l}-0.0018 \\
(0.0400)\end{array}$ \\
\hline Log(population) & $\begin{array}{c}-2.0149^{* *} \\
(0.9183)\end{array}$ & $\begin{array}{c}-4.5017^{* *} \\
(2.0291)\end{array}$ & $\begin{array}{c}-7.6109^{* *} \\
(3.3288)\end{array}$ & $\begin{array}{c}10.6552^{* *} \\
(4.7070)\end{array}$ & $\begin{array}{c}10.5188^{* *} \\
(5.2533)\end{array}$ \\
\hline Population density & $\begin{array}{c}0.0001 \\
(0.0001)\end{array}$ & $\begin{array}{l}0.0002^{*} \\
(0.0001)\end{array}$ & $\begin{array}{c}0.0004^{*} \\
(0.0002)\end{array}$ & $\begin{array}{l}-0.0006^{*} \\
(0.0004)\end{array}$ & $\begin{array}{c}-0.0007^{*} \\
(0.0004)\end{array}$ \\
\hline Share of illiteracy & $\begin{array}{c}-0.0224^{*} \\
(0.0116)\end{array}$ & $\begin{array}{c}-0.0446^{*} \\
(0.0228)\end{array}$ & $\begin{array}{c}-0.0744^{* *} \\
(0.0370)\end{array}$ & $\begin{array}{l}0.0921^{*} \\
(0.0537)\end{array}$ & $\begin{array}{c}0.0778 \\
(0.0612)\end{array}$ \\
\hline Average years of schooling & $\begin{array}{c}-0.5359^{* * *} \\
(0.1774)\end{array}$ & $\begin{array}{c}-1.0948^{* * * *} \\
(0.3921)\end{array}$ & $\begin{array}{r}-1.6934^{* *} \\
(0.6846)\end{array}$ & $\begin{array}{c}1.7382^{*} \\
(1.0389)\end{array}$ & $\begin{array}{c}1.1854 \\
(1.2054)\end{array}$ \\
\hline $\begin{array}{l}\text { Income per capita (in minimum } \\
\text { wages) }\end{array}$ & -0.4102 & -1.4877 & -2.6028 & 3.2687 & 2.8243 \\
\hline & $(0.4690)$ & $(1.0566)$ & $(1.7942)$ & $(2.5776)$ & $(2.7736)$ \\
\hline Log(number of households) & $\begin{array}{l}1.8295^{* *} \\
(0.9195)\end{array}$ & $\begin{array}{l}4.1080^{* *} \\
(2.0253)\end{array}$ & $\begin{array}{l}6.9994^{* *} \\
(3.3191)\end{array}$ & $\begin{array}{c}-10.0123^{* *} \\
(4.7084)\end{array}$ & $\begin{array}{c}-9.9541^{*} \\
(5.2645)\end{array}$ \\
\hline Life expectancy & $\begin{array}{c}-0.0576^{* * *} \\
(0.0218)\end{array}$ & $\begin{array}{c}-0.1336^{* * *} \\
(0.0485)\end{array}$ & $\begin{array}{c}-0.2311^{* * *} \\
(0.0816)\end{array}$ & $\begin{array}{c}0.3326^{* * *} \\
(0.1162)\end{array}$ & $\begin{array}{c}0.3254^{* *} \\
(0.1269)\end{array}$ \\
\hline Share of pop. occupied & $\begin{array}{c}2.3384^{*} \\
(1.3620)\end{array}$ & $\begin{array}{l}5.2997^{*} \\
(2.9758)\end{array}$ & $\begin{array}{l}8.6168^{*} \\
(5.0028)\end{array}$ & $\begin{array}{c}-14.1938^{* *} \\
(7.2054)\end{array}$ & $\begin{array}{c}-17.8625^{* *} \\
(8.2101)\end{array}$ \\
\hline Share of households with sanitation & $\begin{array}{c}0.0004 \\
(0.0056)\end{array}$ & $\begin{array}{l}-0.0021 \\
(0.0129)\end{array}$ & $\begin{array}{l}-0.0132 \\
(0.0228)\end{array}$ & $\begin{array}{c}0.0276 \\
(0.0352)\end{array}$ & $\begin{array}{c}0.0363 \\
(0.0407)\end{array}$ \\
\hline $\begin{array}{l}\text { Share of households with piped } \\
\text { water }\end{array}$ & 0.0054 & 0.0087 & 0.0155 & -0.0164 & -0.0202 \\
\hline & $(0.0055)$ & $(0.0141)$ & $(0.0255)$ & $(0.0384)$ & $(0.0437)$ \\
\hline Share of households with electricity & $\begin{array}{c}0.0053 \\
(0.0064)\end{array}$ & $\begin{array}{c}0.0173 \\
(0.0150)\end{array}$ & $\begin{array}{c}0.0324 \\
(0.0262)\end{array}$ & $\begin{array}{l}-0.0342 \\
(0.0392)\end{array}$ & $\begin{array}{l}-0.0200 \\
(0.0448)\end{array}$ \\
\hline Share of pop. in poverty & $\begin{array}{l}-0.0102 \\
(0.0112)\end{array}$ & $\begin{array}{l}-0.0343 \\
(0.0236)\end{array}$ & $\begin{array}{r}-0.0639^{*} \\
(0.0383)\end{array}$ & $\begin{array}{c}0.0929^{*} \\
(0.0544)\end{array}$ & $\begin{array}{l}0.1053^{*} \\
(0.0587)\end{array}$ \\
\hline Observations & 278 & 278 & 278 & 278 & 278 \\
\hline R-squared & 0.24 & 0.28 & 0.28 & 0.26 & 0.22 \\
\hline
\end{tabular}

Robust standard errors in parentheses: ${ }^{*} p<0.10,{ }^{* *} p<0.05,{ }^{* * *} p<0.01$ 


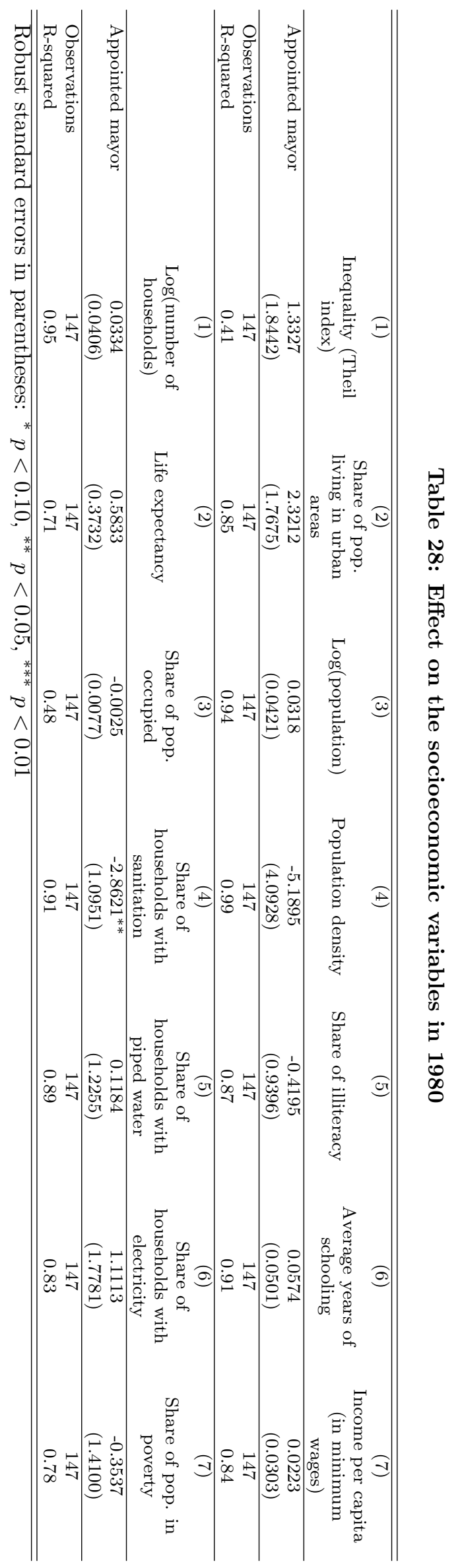




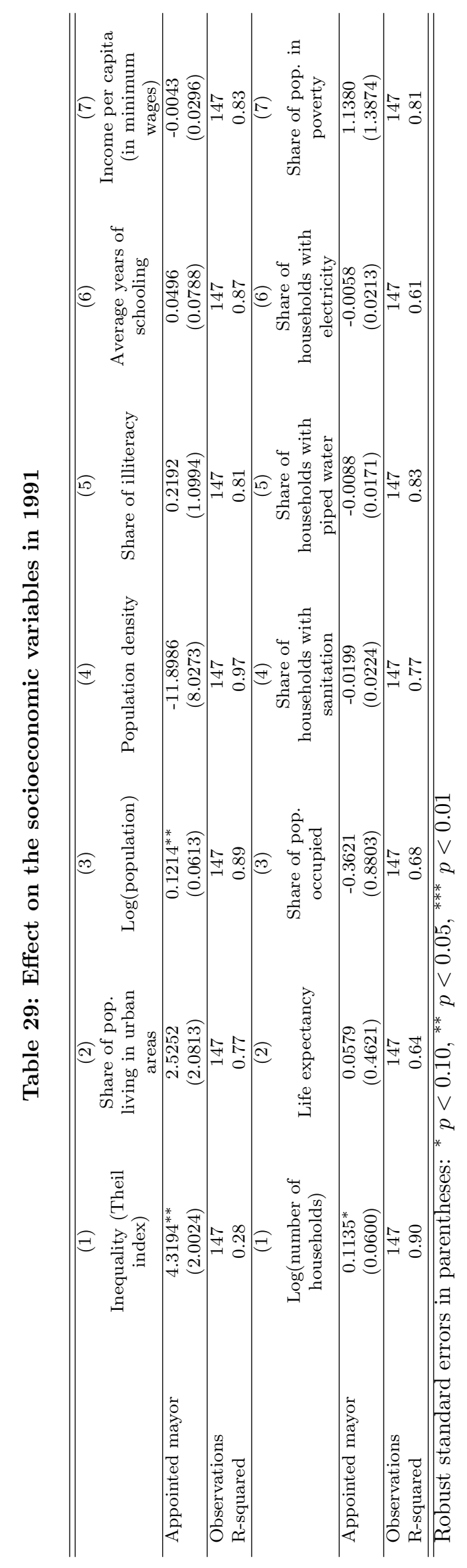




\section{Appendix B}

Table 30: Possible selection in Globo's coverage

Dependent variable $=1$ if Globo coverage in year $\mathrm{t}$

Globo coverage $=1$ if municipality receives Globo signal 6 months before the election

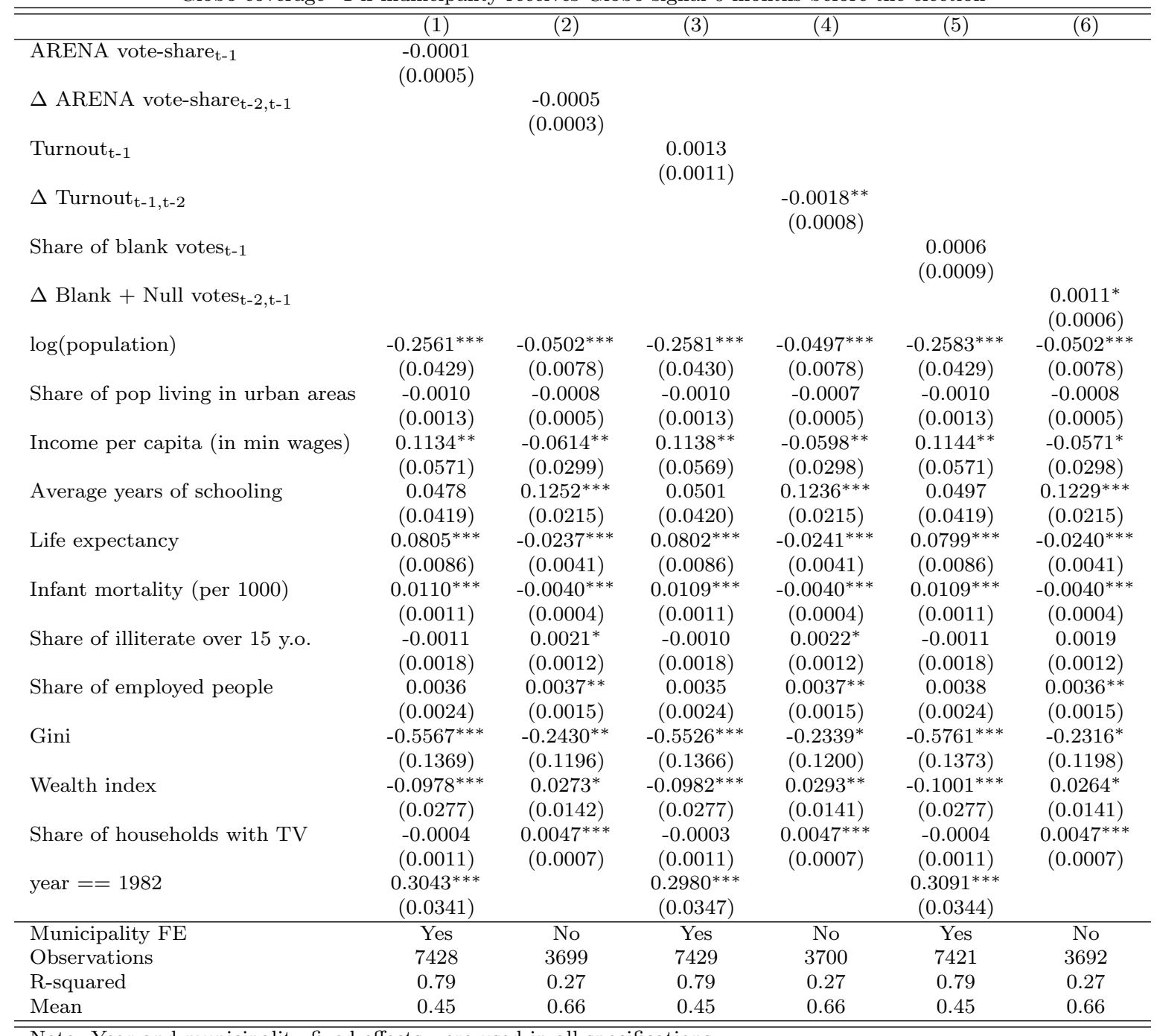

Note: Year and municipality fixed-effects were used in all specifications

Standard errors clustered at the municipality level in parentheses: ${ }^{*} p<0.10,{ }^{* *} p<0.05,{ }^{* * *} p<0.01$ 
Table 31: Possible selection in Globo's coverage

Dependent variable $=1$ if Globo coverage in year $t$

Globo coverage $=1$ if municipality receives Globo's signal 1 year before the election

\begin{tabular}{|c|c|c|c|c|c|c|}
\hline & (1) & $(2)$ & (3) & (4) & (5) & (6) \\
\hline ARENA vote-share t-1 $_{\text {. }}$ & $\begin{array}{l}-0.0002 \\
(0.0005)\end{array}$ & & & & & \\
\hline$\Delta$ ARENA vote-sharet-2,t-1 & & $\begin{array}{l}-0.0005 \\
(0.0003)\end{array}$ & & & & \\
\hline Turnout $_{\mathrm{t}-1}$ & & & $\begin{array}{c}0.0008 \\
(0.0011)\end{array}$ & & & \\
\hline$\Delta$ Turnout $_{\mathrm{t}-1, \mathrm{t}-2}$ & & & & $\begin{array}{c}-0.0019^{* *} \\
(0.0008)\end{array}$ & & \\
\hline Share of blank votest-1 & & & & & $\begin{array}{c}0.0009 \\
(0.0009)\end{array}$ & \\
\hline$\Delta$ Blank + Null votest-2,t-1 & & & & & & $\begin{array}{c}0.0012^{* *} \\
(0.0006)\end{array}$ \\
\hline $\log ($ population) & $\begin{array}{c}-0.3239^{* * *} \\
(0.0428)\end{array}$ & $\begin{array}{c}-0.0490^{* * *} \\
(0.0081)\end{array}$ & $\begin{array}{c}-0.3248^{* * *} \\
(0.0428)\end{array}$ & $\begin{array}{c}-0.0483^{* * *} \\
(0.0081)\end{array}$ & $\begin{array}{c}-0.3268^{* * *} \\
(0.0427)\end{array}$ & $\begin{array}{c}-0.0488^{* * *} \\
(0.0082)\end{array}$ \\
\hline Share of pop living in urban areas & $\begin{array}{l}0.0027^{*} \\
(0.0014)\end{array}$ & $\begin{array}{l}-0.0006 \\
(0.0005)\end{array}$ & $\begin{array}{l}0.0027^{*} \\
(0.0014)\end{array}$ & $\begin{array}{l}-0.0005 \\
(0.0005)\end{array}$ & $\begin{array}{l}0.0027^{*} \\
(0.0014)\end{array}$ & $\begin{array}{l}-0.0007 \\
(0.0005)\end{array}$ \\
\hline Income per capita (in min wages) & $\begin{array}{c}0.0487 \\
(0.0527)\end{array}$ & $\begin{array}{l}-0.0402 \\
(0.0317)\end{array}$ & $\begin{array}{c}0.0495 \\
(0.0526)\end{array}$ & $\begin{array}{l}-0.0373 \\
(0.0316)\end{array}$ & $\begin{array}{c}0.0509 \\
(0.0527)\end{array}$ & $\begin{array}{l}-0.0344 \\
(0.0315)\end{array}$ \\
\hline Average years of schooling & $\begin{array}{c}0.0296 \\
(0.0415)\end{array}$ & $\begin{array}{c}0.1042^{* * *} \\
(0.0226)\end{array}$ & $\begin{array}{c}0.0316 \\
(0.0415)\end{array}$ & $\begin{array}{c}0.1024^{* * *} \\
(0.0225)\end{array}$ & $\begin{array}{c}0.0319 \\
(0.0414)\end{array}$ & $\begin{array}{c}0.1016^{* * *} \\
(0.0226)\end{array}$ \\
\hline Life expectancy & $\begin{array}{c}0.0740^{* * *} \\
(0.0085)\end{array}$ & $\begin{array}{c}-0.0233^{* * *} \\
(0.0042)\end{array}$ & $\begin{array}{c}0.0739^{* * *} \\
(0.0085)\end{array}$ & $\begin{array}{c}-0.0235^{* * *} \\
(0.0042)\end{array}$ & $\begin{array}{c}0.0736^{* * *} \\
(0.0086)\end{array}$ & $\begin{array}{c}-0.0235^{* * *} \\
(0.0042)\end{array}$ \\
\hline Infant mortality (per 1000) & $\begin{array}{c}0.0103^{* * *} \\
(0.0011)\end{array}$ & $\begin{array}{c}-0.0042^{* * *} \\
(0.0004)\end{array}$ & $\begin{array}{c}0.0103^{* * *} \\
(0.0011)\end{array}$ & $\begin{array}{c}-0.0042^{* * *} \\
(0.0004)\end{array}$ & $\begin{array}{c}0.0103^{* * *} \\
(0.0011)\end{array}$ & $\begin{array}{c}-0.0042^{* * *} \\
(0.0004)\end{array}$ \\
\hline Share of illiterate over 15 y.o. & $\begin{array}{l}-0.0006 \\
(0.0018)\end{array}$ & $\begin{array}{c}0.0020 \\
(0.0012)\end{array}$ & $\begin{array}{l}-0.0005 \\
(0.0018)\end{array}$ & $\begin{array}{l}0.0020^{*} \\
(0.0012)\end{array}$ & $\begin{array}{l}-0.0006 \\
(0.0018)\end{array}$ & $\begin{array}{c}0.0018 \\
(0.0012)\end{array}$ \\
\hline Share of employed people & $\begin{array}{c}0.0017 \\
(0.0024)\end{array}$ & $\begin{array}{c}0.0029^{*} \\
(0.0015)\end{array}$ & $\begin{array}{c}0.0016 \\
(0.0024)\end{array}$ & $\begin{array}{l}0.0029^{*} \\
(0.0015)\end{array}$ & $\begin{array}{c}0.0019 \\
(0.0024)\end{array}$ & $\begin{array}{l}0.0028^{*} \\
(0.0015)\end{array}$ \\
\hline Gini & $\begin{array}{c}-0.5026^{* * *} \\
(0.1375)\end{array}$ & $\begin{array}{c}-0.3538^{* * *} \\
(0.1210)\end{array}$ & $\begin{array}{c}-0.4978^{* * *} \\
(0.1373)\end{array}$ & $\begin{array}{c}-0.3421^{* * *} \\
(0.1213)\end{array}$ & $\begin{array}{c}-0.5189^{* * *} \\
(0.1379)\end{array}$ & $\begin{array}{c}-0.3395^{* * *} \\
(0.1211)\end{array}$ \\
\hline Wealth index & $\begin{array}{c}-0.0720^{* *} \\
(0.0280)\end{array}$ & $\begin{array}{c}-0.0008 \\
(0.0150)\end{array}$ & $\begin{array}{c}-0.0729^{* * *} \\
(0.0280)\end{array}$ & $\begin{array}{c}0.0011 \\
(0.0149)\end{array}$ & $\begin{array}{c}-0.0755^{* * *} \\
(0.0280)\end{array}$ & $\begin{array}{c}-0.0018 \\
(0.0149)\end{array}$ \\
\hline Share of households with TV & $\begin{array}{c}0.0008 \\
(0.0011)\end{array}$ & $\begin{array}{c}0.0045^{* * *} \\
(0.0007)\end{array}$ & $\begin{array}{c}0.0009 \\
(0.0011)\end{array}$ & $\begin{array}{c}0.0044^{* * *} \\
(0.0007)\end{array}$ & $\begin{array}{c}0.0008 \\
(0.0011)\end{array}$ & $\begin{array}{c}0.0044^{* * *} \\
(0.0007)\end{array}$ \\
\hline year $==1982$ & $\begin{array}{c}0.3385^{* * *} \\
(0.0347)\end{array}$ & & $\begin{array}{c}0.3334^{* * *} \\
(0.0352)\end{array}$ & & $\begin{array}{c}0.3434^{* * *} \\
(0.0350)\end{array}$ & \\
\hline Municipality FE & Yes & No & Yes & No & Yes & No \\
\hline Observations & 7428 & 3699 & 7429 & 3700 & 7421 & 3692 \\
\hline R-squared & 0.78 & 0.25 & 0.78 & 0.25 & 0.78 & 0.25 \\
\hline Mean & 0.41 & 0.63 & 0.41 & 0.63 & 0.41 & 0.63 \\
\hline
\end{tabular}

Note: Year and municipality fixed-effects were used in all specifications

Standard errors clustered at the municipality level in parentheses: ${ }^{*} p<0.10,{ }^{* *} p<0.05,{ }^{* * *} p<0.01$ 
Table 32: Effect of Globo on ARENA's vote-share

Dependent variable: ARENA's vote-share in t, $\mathrm{t}=1972,1976,1982$ Globo coverage=1 if municipality receives Globo's signal 6 months before the election

\begin{tabular}{|c|c|c|c|}
\hline & $\begin{array}{c}(1) \\
\text { ARENA }\end{array}$ & $\begin{array}{c}(2) \\
\text { Turnout }\end{array}$ & $\begin{array}{c}(3) \\
\text { Blank and null }\end{array}$ \\
\hline Globo $*$ year $==1972$ & $\begin{array}{c}4.1694^{* * *} \\
(1.5819)\end{array}$ & $\begin{array}{l}-0.9291 \\
(0.5777)\end{array}$ & $\begin{array}{c}-0.2570 \\
(0.8033)\end{array}$ \\
\hline Globo $*$ year $==1976$ & $\begin{array}{l}-2.2179^{* *} \\
(0.8677)\end{array}$ & $\begin{array}{c}-0.7642^{* *} \\
(0.3311)\end{array}$ & $\begin{array}{l}-0.1681 \\
(0.3886)\end{array}$ \\
\hline Globo $*$ year $==1982$ & $\begin{array}{c}-2.4453^{* *} \\
(1.0528)\end{array}$ & $\begin{array}{c}1.3079 * * * \\
(0.4451)\end{array}$ & $\begin{array}{l}-0.1263 \\
(0.4069)\end{array}$ \\
\hline $\log ($ population $)$ & $\begin{array}{c}-5.9612^{* * *} \\
(1.5471)\end{array}$ & $\begin{array}{c}-2.7450^{* * *} \\
(0.6606)\end{array}$ & $\begin{array}{c}2.2221^{* * *} \\
(0.5541)\end{array}$ \\
\hline Share of pop living in urban areas & $\begin{array}{c}-0.1913^{* * *} \\
(0.0510)\end{array}$ & $\begin{array}{l}-0.0287 \\
(0.0188)\end{array}$ & $\begin{array}{c}0.0210 \\
(0.0175)\end{array}$ \\
\hline Income per capita (in min wages) & $\begin{array}{l}-2.7047 \\
(2.1095)\end{array}$ & $\begin{array}{c}1.8041^{* * *} \\
(0.5825)\end{array}$ & $\begin{array}{c}-2.0125^{* * *} \\
(0.5941)\end{array}$ \\
\hline Average years of schooling & $\begin{array}{c}-6.1607^{* * *} \\
(1.5726)\end{array}$ & $\begin{array}{l}-0.7126 \\
(0.6390)\end{array}$ & $\begin{array}{c}0.8536 \\
(0.6214)\end{array}$ \\
\hline Life expectancy & $\begin{array}{l}-0.6553^{*} \\
(0.3377)\end{array}$ & $\begin{array}{l}0.2782^{* *} \\
(0.1352)\end{array}$ & $\begin{array}{c}-0.2899^{* *} \\
(0.1345)\end{array}$ \\
\hline Infant mortality (per 1000) & $\begin{array}{l}-0.0467 \\
(0.0468)\end{array}$ & $\begin{array}{l}0.0358^{*} \\
(0.0189)\end{array}$ & $\begin{array}{r}-0.0437^{* *} \\
(0.0182)\end{array}$ \\
\hline Share of illiterate over 15 y.o. & $\begin{array}{l}-0.0146 \\
(0.0721)\end{array}$ & $\begin{array}{l}-0.0571^{*} \\
(0.0318)\end{array}$ & $\begin{array}{l}0.0532^{*} \\
(0.0296)\end{array}$ \\
\hline Share of employed people & $\begin{array}{c}0.0531 \\
(0.0919)\end{array}$ & $\begin{array}{c}0.0269 \\
(0.0376)\end{array}$ & $\begin{array}{l}-0.0333 \\
(0.0332)\end{array}$ \\
\hline Gini & $\begin{array}{c}3.9989 \\
(5.5809)\end{array}$ & $\begin{array}{c}-7.7178^{* * *} \\
(2.2965)\end{array}$ & $\begin{array}{l}-0.4949 \\
(2.1943)\end{array}$ \\
\hline Wealth index & $\begin{array}{l}-0.6947 \\
(1.0302)\end{array}$ & $\begin{array}{l}-0.1348 \\
(0.3970)\end{array}$ & $\begin{array}{c}1.0327^{* * *} \\
(0.3765)\end{array}$ \\
\hline Share of households with TV & $\begin{array}{c}-0.0844^{* *} \\
(0.0416)\end{array}$ & $\begin{array}{c}-0.0600^{* * *} \\
(0.0153)\end{array}$ & $\begin{array}{c}0.0093 \\
(0.0149)\end{array}$ \\
\hline year $==1976$ & $\begin{array}{c}-4.2668^{* * *} \\
(0.4840)\end{array}$ & $\begin{array}{c}4.0947^{* * *} \\
(0.2198)\end{array}$ & $\begin{array}{c}-4.2041^{* * *} \\
(0.2844)\end{array}$ \\
\hline year $==1982$ & $\begin{array}{c}-3.9935 * * * \\
(1.4955)\end{array}$ & $\begin{array}{c}4.4651^{* * *} \\
(0.5946)\end{array}$ & $\begin{array}{c}-1.4678^{* *} \\
(0.5816)\end{array}$ \\
\hline Observations & 11206 & 11209 & 11200 \\
\hline R-squared & 0.69 & 0.72 & 0.43 \\
\hline Mean & 67.48 & 79.91 & 8.45 \\
\hline
\end{tabular}

Note: Year and municipality fixed-effects were used in all specifications

Standard errors clustered at the municipality level in parentheses: ${ }^{*} p<0.10,{ }^{* *} p<0.05,{ }^{* * *} p<0.01$ 
Table 33: Effect of Globo on ARENA's vote-share

Dependent variable: ARENA's vote-share in t, t=1972, 1976, 1982 Globo coverage=1 if municipality receives Globo's signal 1 year before the election

\begin{tabular}{|c|c|c|c|}
\hline & $\begin{array}{c}(1) \\
\text { ARENA }\end{array}$ & $\begin{array}{c}\text { (2) } \\
\text { Turnout }\end{array}$ & $\begin{array}{c}(3) \\
\text { Blank and null }\end{array}$ \\
\hline Globo $*$ year $==1972$ & $\begin{array}{l}4.0247^{* *} \\
(1.8611)\end{array}$ & $\begin{array}{c}-1.4135^{* *} \\
(0.5912)\end{array}$ & $\begin{array}{c}0.0905 \\
(0.8825)\end{array}$ \\
\hline Globo $*$ year $==1976$ & $\begin{array}{c}-3.6608^{* * *} \\
(0.9285)\end{array}$ & $\begin{array}{c}-0.9497^{* * *} \\
(0.3612)\end{array}$ & $\begin{array}{c}0.2298 \\
(0.4399)\end{array}$ \\
\hline Globo $*$ year $==1982$ & $\begin{array}{c}-2.6027^{* *} \\
(1.0192)\end{array}$ & $\begin{array}{l}1.0612^{* *} \\
(0.4234)\end{array}$ & $\begin{array}{c}0.4262 \\
(0.3896)\end{array}$ \\
\hline $\log$ (population) & $\begin{array}{c}-6.1348^{* * *} \\
(1.5456)\end{array}$ & $\begin{array}{c}-2.9030^{* * *} \\
(0.6657)\end{array}$ & $\begin{array}{c}2.3680^{* * *} \\
(0.5582)\end{array}$ \\
\hline Share of pop living in urban areas & $\begin{array}{c}-0.1854^{* * *} \\
(0.0509)\end{array}$ & $\begin{array}{l}-0.0275 \\
(0.0189)\end{array}$ & $\begin{array}{c}0.0203 \\
(0.0174)\end{array}$ \\
\hline Income per capita (in min wages) & $\begin{array}{l}-2.8223 \\
(2.1083)\end{array}$ & $\begin{array}{c}1.7758^{* * * *} \\
(0.5843)\end{array}$ & $\begin{array}{c}-2.0541^{* * *} \\
(0.5906)\end{array}$ \\
\hline Average years of schooling & $\begin{array}{c}-6.1887^{* * *} \\
(1.5721)\end{array}$ & $\begin{array}{l}-0.6983 \\
(0.6385)\end{array}$ & $\begin{array}{c}0.8513 \\
(0.6212)\end{array}$ \\
\hline Life expectancy & $\begin{array}{l}-0.6106^{*} \\
(0.3368)\end{array}$ & $\begin{array}{l}0.2814^{* *} \\
(0.1351)\end{array}$ & $\begin{array}{c}-0.3307^{* *} \\
(0.1338)\end{array}$ \\
\hline Infant mortality (per 1000) & $\begin{array}{l}-0.0392 \\
(0.0467)\end{array}$ & $\begin{array}{l}0.0360^{*} \\
(0.0189)\end{array}$ & $\begin{array}{c}-0.0493^{* * *} \\
(0.0181)\end{array}$ \\
\hline Share of illiterate over 15 y.o. & $\begin{array}{l}-0.0133 \\
(0.0721)\end{array}$ & $\begin{array}{r}-0.0576^{*} \\
(0.0318)\end{array}$ & $\begin{array}{l}0.0532^{*} \\
(0.0296)\end{array}$ \\
\hline Share of employed people & $\begin{array}{c}0.0507 \\
(0.0916)\end{array}$ & $\begin{array}{c}0.0276 \\
(0.0376)\end{array}$ & $\begin{array}{l}-0.0349 \\
(0.0332)\end{array}$ \\
\hline Gini & $\begin{array}{c}4.3031 \\
(5.5768)\end{array}$ & $\begin{array}{c}-7.8912^{* * *} \\
(2.2932)\end{array}$ & $\begin{array}{l}-0.2375 \\
(2.1968)\end{array}$ \\
\hline Wealth index & $\begin{array}{l}-0.7353 \\
(1.0279)\end{array}$ & $\begin{array}{l}-0.1130 \\
(0.3979)\end{array}$ & $\begin{array}{c}1.0643^{* * *} \\
(0.3755)\end{array}$ \\
\hline Share of households with TV & $\begin{array}{c}-0.0871^{* *} \\
(0.0415)\end{array}$ & $\begin{array}{c}-0.0582^{* * *} \\
(0.0152)\end{array}$ & $\begin{array}{c}0.0071 \\
(0.0149)\end{array}$ \\
\hline year $=1976$ & $\begin{array}{c}-4.2500^{* * *} \\
(0.4680)\end{array}$ & $\begin{array}{c}4.0754^{* * *} \\
(0.2110)\end{array}$ & $\begin{array}{c}-4.2595^{* * *} \\
(0.2726)\end{array}$ \\
\hline year $==1982$ & $\begin{array}{c}-3.9522^{* * *} \\
(1.4741)\end{array}$ & $\begin{array}{c}4.6020^{* * *} \\
(0.5877)\end{array}$ & $\begin{array}{c}-1.6996^{* * *} \\
(0.5803)\end{array}$ \\
\hline Observations & 11206 & 11209 & 11200 \\
\hline R-squared & 0.69 & 0.72 & 0.43 \\
\hline Mean & 67.48 & 79.91 & 8.45 \\
\hline
\end{tabular}

Note: Year and municipality fixed-effects were used in all specifications

Standard errors clustered at the municipality level in parentheses: ${ }^{*} p<0.10,{ }^{* *} p<0.05,{ }^{* * *} p<0.01$ 
Table 34: Possible selection in Globo's coverage (Turnout)

Dependent variable $=1$ if Globo coverage in year $\mathrm{t}, \mathrm{t}=1976,1982$

\begin{tabular}{|c|c|c|c|c|c|}
\hline & $(1)$ & $(2)$ & $(3)$ & (4) & $(5)$ \\
\hline Turnout $_{t-1}$ & $\begin{array}{c}0.0096^{* * *} \\
(0.0005)\end{array}$ & $\begin{array}{c}0.0029^{* * *} \\
(0.0006)\end{array}$ & $\begin{array}{c}0.0013 \\
(0.0011)\end{array}$ & & \\
\hline$\Delta$ Turnout $_{\mathrm{t}-1, \mathrm{t}-2}$ & & & & $\begin{array}{c}-0.0035^{* * *} \\
(0.0009)\end{array}$ & $\begin{array}{c}-0.0019^{* *} \\
(0.0008)\end{array}$ \\
\hline $\log ($ population $)$ & & $\begin{array}{c}-0.0404^{* * *} \\
(0.0065)\end{array}$ & $\begin{array}{c}-0.2748^{* * *} \\
(0.0429)\end{array}$ & & $\begin{array}{c}-0.0486^{* * *} \\
(0.0078)\end{array}$ \\
\hline Share of pop living in urban areas & & $\begin{array}{c}0.0002 \\
(0.0004)\end{array}$ & $\begin{array}{l}-0.0007 \\
(0.0013)\end{array}$ & & $\begin{array}{l}-0.0007 \\
(0.0005)\end{array}$ \\
\hline Income per capita (in min wages) & & $\begin{array}{l}-0.0109 \\
(0.0249)\end{array}$ & $\begin{array}{c}0.0705 \\
(0.0554)\end{array}$ & & $\begin{array}{c}-0.0658^{* *} \\
(0.0298)\end{array}$ \\
\hline Average years of schooling & & $\begin{array}{c}0.0610^{* * *} \\
(0.0172)\end{array}$ & $\begin{array}{l}0.0718^{*} \\
(0.0418)\end{array}$ & & $\begin{array}{c}0.1245^{* * *} \\
(0.0214)\end{array}$ \\
\hline Life expectancy & & $\begin{array}{c}0.0025 \\
(0.0028)\end{array}$ & $\begin{array}{c}0.0815^{* * * *} \\
(0.0086)\end{array}$ & & $\begin{array}{c}-0.0236^{* * *} \\
(0.0041)\end{array}$ \\
\hline Infant mortality (per 1.000 habitants) & & $\begin{array}{l}-0.0005^{*} \\
(0.0003)\end{array}$ & $\begin{array}{c}0.0110^{* * *} \\
(0.0011)\end{array}$ & & $\begin{array}{c}-0.0040^{* * *} \\
(0.0004)\end{array}$ \\
\hline Share of illiterate over 15 y.o. & & $\begin{array}{l}-0.0003 \\
(0.0008)\end{array}$ & $\begin{array}{l}-0.0009 \\
(0.0018)\end{array}$ & & $\begin{array}{l}0.0021^{*} \\
(0.0012)\end{array}$ \\
\hline Share of employed people & & $\begin{array}{l}0.0021^{*} \\
(0.0012)\end{array}$ & $\begin{array}{c}0.0039 \\
(0.0024)\end{array}$ & & $\begin{array}{l}0.0038^{* *} \\
(0.0015)\end{array}$ \\
\hline Gini & & $\begin{array}{c}-0.4030^{* * *} \\
(0.0749)\end{array}$ & $\begin{array}{c}-0.5512^{* * *} \\
(0.1372)\end{array}$ & & $\begin{array}{c}-0.2477^{* *} \\
(0.1198)\end{array}$ \\
\hline Wealth index & & $\begin{array}{l}-0.0081 \\
(0.0105)\end{array}$ & $\begin{array}{c}-0.0921^{* * *} \\
(0.0278)\end{array}$ & & $\begin{array}{c}0.0316^{* *} \\
(0.0140)\end{array}$ \\
\hline Share of households with TV & & $\begin{array}{c}0.0051^{* * *} \\
(0.0006)\end{array}$ & $\begin{array}{l}-0.0009 \\
(0.0011)\end{array}$ & & $\begin{array}{c}0.0047^{* * *} \\
(0.0007)\end{array}$ \\
\hline year $==1982$ & $\begin{array}{c}0.3707^{* * * *} \\
(0.0089)\end{array}$ & $\begin{array}{c}0.2021^{* * *} \\
(0.0146)\end{array}$ & $\begin{array}{c}0.3061^{* * *} \\
(0.0347)\end{array}$ & & \\
\hline Municipality FE & No & No & Yes & No & No \\
\hline Observations & 7429 & 7429 & 7429 & 3700 & 3700 \\
\hline R-squared & 0.21 & 0.31 & 0.79 & 0.00 & 0.27 \\
\hline Mean & 0.46 & 0.46 & 0.46 & 0.66 & 0.66 \\
\hline
\end{tabular}

Standard errors clustered at the municipality level in parentheses: ${ }^{*} p<0.10,^{* *} p<0.05,{ }^{* * *} p<0.01$ 
Table 35: Possible selection in Globo's coverage (share of blank and null votes)

Dependent variable $=1$ if Globo coverage in year $t, t=1976,1982$

\begin{tabular}{|c|c|c|c|c|c|}
\hline & (1) & $(2)$ & $(3)$ & $(4)$ & $(5)$ \\
\hline Share of blank votes $\mathrm{t}_{\mathrm{t}-1}$ & $\begin{array}{c}0.0020^{* * *} \\
(0.0006)\end{array}$ & $\begin{array}{c}0.0013^{* *} \\
(0.0005)\end{array}$ & $\begin{array}{c}0.0005 \\
(0.0009)\end{array}$ & & \\
\hline$\Delta$ Blank + Null votest-2,t-1 & & & & $\begin{array}{l}-0.0004 \\
(0.0006)\end{array}$ & $\begin{array}{r}0.0012^{* *} \\
(0.0006)\end{array}$ \\
\hline $\log$ (population) & & $\begin{array}{c}-0.0397^{* * *} \\
(0.0065)\end{array}$ & $\begin{array}{c}-0.2744^{* * *} \\
(0.0430)\end{array}$ & & $\begin{array}{c}-0.0491^{* * *} \\
(0.0078)\end{array}$ \\
\hline Share of pop living in urban areas & & $\begin{array}{c}0.0001 \\
(0.0004)\end{array}$ & $\begin{array}{c}-0.0007 \\
(0.0013)\end{array}$ & & $\begin{array}{c}-0.0008^{*} \\
(0.0005)\end{array}$ \\
\hline Income per capita (in min wages) & & $\begin{array}{l}-0.0127 \\
(0.0248)\end{array}$ & $\begin{array}{c}0.0707 \\
(0.0555)\end{array}$ & & $\begin{array}{c}-0.0629^{* *} \\
(0.0297)\end{array}$ \\
\hline Average years of schooling & & $\begin{array}{c}0.0710^{* * *} \\
(0.0172)\end{array}$ & $\begin{array}{l}0.0713^{*} \\
(0.0418)\end{array}$ & & $\begin{array}{c}0.1238^{* * *} \\
(0.0214)\end{array}$ \\
\hline Life expectancy & & $\begin{array}{c}0.0045 \\
(0.0028)\end{array}$ & $\begin{array}{c}0.0812^{* * *} \\
(0.0087)\end{array}$ & & $\begin{array}{c}-0.0235^{* * *} \\
(0.0041)\end{array}$ \\
\hline Infant mortality (per 1000) & & $\begin{array}{l}-0.0003 \\
(0.0003)\end{array}$ & $\begin{array}{c}0.0110^{* * * *} \\
(0.0011)\end{array}$ & & $\begin{array}{c}-0.0040^{* * *} \\
(0.0004)\end{array}$ \\
\hline Share of illiterate over 15 y.o. & & $\begin{array}{l}-0.0007 \\
(0.0008)\end{array}$ & $\begin{array}{l}-0.0010 \\
(0.0018)\end{array}$ & & $\begin{array}{c}0.0019 \\
(0.0012)\end{array}$ \\
\hline Share of employed people & & $\begin{array}{l}0.0021^{*} \\
(0.0012)\end{array}$ & $\begin{array}{l}0.0042^{*} \\
(0.0024)\end{array}$ & & $\begin{array}{c}0.0037^{* *} \\
(0.0015)\end{array}$ \\
\hline Gini & & $\begin{array}{c}-0.4381^{* * *} \\
(0.0750)\end{array}$ & $\begin{array}{c}-0.5749^{* * *} \\
(0.1378)\end{array}$ & & $\begin{array}{c}-0.2450^{* *} \\
(0.1196)\end{array}$ \\
\hline Wealth index & & $\begin{array}{l}-0.0035 \\
(0.0104)\end{array}$ & $\begin{array}{c}-0.0939^{* * *} \\
(0.0278)\end{array}$ & & $\begin{array}{l}0.0287^{* *} \\
(0.0141)\end{array}$ \\
\hline Share of households with TV & & $\begin{array}{c}0.0052^{* * *} \\
(0.0006)\end{array}$ & $\begin{array}{l}-0.0010 \\
(0.0011)\end{array}$ & & $\begin{array}{c}0.0047^{* * *} \\
(0.0007)\end{array}$ \\
\hline year $==1982$ & $\begin{array}{c}0.4173^{* * * *} \\
(0.0083)\end{array}$ & $\begin{array}{c}0.2080^{* * *} \\
(0.0147)\end{array}$ & $\begin{array}{c}0.3168^{* * *} \\
(0.0344)\end{array}$ & & \\
\hline Municipality FE & No & No & Yes & No & No \\
\hline Observations & 7421 & 7421 & 7421 & 3692 & 3692 \\
\hline R-squared & 0.17 & 0.31 & 0.79 & 0.00 & 0.27 \\
\hline Mean & 0.46 & 0.46 & 0.46 & 0.66 & 0.66 \\
\hline
\end{tabular}


Table 36: Effect of Globo on turnout vote-share

Dependent variable: Turnout in $t, t=1972,1976,1982$

\begin{tabular}{|c|c|c|c|c|c|c|}
\hline & (1) & $(2)$ & (3) & (4) & (5) & (6) \\
\hline Globo & $\begin{array}{c}5.2077^{* * *} \\
(0.2478)\end{array}$ & $\begin{array}{c}1.3639^{* * *} \\
(0.2337)\end{array}$ & $\begin{array}{c}0.1308 \\
(0.3110)\end{array}$ & & & \\
\hline Globo $*$ year $==1972$ & & & & $\begin{array}{c}4.5688^{* * *} \\
(0.5907)\end{array}$ & $\begin{array}{c}2.0127^{* * *} \\
(0.5369)\end{array}$ & $\begin{array}{l}-0.9373 \\
(0.5757)\end{array}$ \\
\hline Globo $*$ year $==1976$ & & & & $\begin{array}{c}4.0400^{* * *} \\
(0.3285)\end{array}$ & $\begin{array}{c}1.7103^{* * *} \\
(0.2930)\end{array}$ & $\begin{array}{c}-0.7704^{* *} \\
(0.3254)\end{array}$ \\
\hline Globo $*$ year $==1982$ & & & & $\begin{array}{c}6.3774^{* * *} \\
(0.3063)\end{array}$ & $\begin{array}{l}0.7728^{* *} \\
(0.3223)\end{array}$ & $\begin{array}{c}1.2665^{* * *} \\
(0.4466)\end{array}$ \\
\hline $\log$ (population) & & $\begin{array}{c}-0.7449^{* * *} \\
(0.1285)\end{array}$ & $\begin{array}{c}-2.8995^{* * *} \\
(0.6664)\end{array}$ & & $\begin{array}{c}-0.7631^{* * *} \\
(0.1286)\end{array}$ & $\begin{array}{c}-2.7589^{* * *} \\
(0.6614)\end{array}$ \\
\hline Share of pop living in urban areas & & $\begin{array}{l}-0.0082 \\
(0.0075)\end{array}$ & $\begin{array}{l}-0.0276 \\
(0.0191)\end{array}$ & & $\begin{array}{l}-0.0102 \\
(0.0075)\end{array}$ & $\begin{array}{l}-0.0285 \\
(0.0189)\end{array}$ \\
\hline Income per capita (in min wages) & & $\begin{array}{c}-1.1826^{* *} \\
(0.5314)\end{array}$ & $\begin{array}{c}1.9884^{* * *} \\
(0.5792)\end{array}$ & & $\begin{array}{c}-1.1306^{* *} \\
(0.5299)\end{array}$ & $\begin{array}{c}1.7987^{* * *} \\
(0.5832)\end{array}$ \\
\hline Average years of schooling & & $\begin{array}{c}4.4156^{* * *} \\
(0.3708)\end{array}$ & $\begin{array}{l}-0.7347 \\
(0.6424)\end{array}$ & & $\begin{array}{c}4.4382^{* * *} \\
(0.3704)\end{array}$ & $\begin{array}{l}-0.7005 \\
(0.6394)\end{array}$ \\
\hline Life expectancy & & $\begin{array}{c}0.4664^{* * *} \\
(0.0538)\end{array}$ & $\begin{array}{l}0.3350^{* *} \\
(0.1345)\end{array}$ & & $\begin{array}{c}0.4629^{* * *} \\
(0.0537)\end{array}$ & $\begin{array}{l}0.2791^{* *} \\
(0.1352)\end{array}$ \\
\hline Infant mortality (per 1000) & & $\begin{array}{c}0.0561^{* * *} \\
(0.0051)\end{array}$ & $\begin{array}{l}0.0432^{* *} \\
(0.0188)\end{array}$ & & $\begin{array}{c}0.0556^{* * *} \\
(0.0051)\end{array}$ & $\begin{array}{l}0.0359^{*} \\
(0.0189)\end{array}$ \\
\hline Share of illiterate over 15 y.o. & & $\begin{array}{c}-0.0754^{* * *} \\
(0.0166)\end{array}$ & $\begin{array}{l}-0.0569^{*} \\
(0.0318)\end{array}$ & & $\begin{array}{c}-0.0735^{* * *} \\
(0.0167)\end{array}$ & $\begin{array}{c}-0.0569^{*} \\
(0.0318)\end{array}$ \\
\hline Share of employed people & & $\begin{array}{c}0.0145 \\
(0.0238)\end{array}$ & $\begin{array}{c}0.0295 \\
(0.0375)\end{array}$ & & $\begin{array}{c}0.0144 \\
(0.0238)\end{array}$ & $\begin{array}{c}0.0273 \\
(0.0376)\end{array}$ \\
\hline Gini & & $\begin{array}{c}-7.5858^{* * *} \\
(1.6818)\end{array}$ & $\begin{array}{c}-8.4621^{* * *} \\
(2.2927)\end{array}$ & & $\begin{array}{c}-7.5126^{* * *} \\
(1.6813)\end{array}$ & $\begin{array}{c}-7.7513^{* * *} \\
(2.2978)\end{array}$ \\
\hline Wealth index & & $\begin{array}{c}1.7612^{* * *} \\
(0.1999)\end{array}$ & $\begin{array}{l}-0.0521 \\
(0.3978)\end{array}$ & & $\begin{array}{c}1.7686^{* * *} \\
(0.1992)\end{array}$ & $\begin{array}{l}-0.1358 \\
(0.3971)\end{array}$ \\
\hline Share of households with TV & & $\begin{array}{c}0.0484^{* * *} \\
(0.0110)\end{array}$ & $\begin{array}{c}-0.0466^{* * *} \\
(0.0148)\end{array}$ & & $\begin{array}{c}0.0524^{* * *} \\
(0.0112)\end{array}$ & $\begin{array}{c}-0.0601^{* * *} \\
(0.0153)\end{array}$ \\
\hline year $==1976$ & $\begin{array}{c}3.1042^{* * *} \\
(0.1689)\end{array}$ & $\begin{array}{c}3.7430^{* * *} \\
(0.1657)\end{array}$ & $\begin{array}{c}3.9650^{* * *} \\
(0.2012)\end{array}$ & $\begin{array}{c}3.3438^{* * *} \\
(0.1912)\end{array}$ & $\begin{array}{c}3.7099^{* * *} \\
(0.1877)\end{array}$ & $\begin{array}{c}4.1023^{* * *} \\
(0.2218)\end{array}$ \\
\hline year $==1982$ & $\begin{array}{c}1.2979^{* * *} \\
(0.2299) \\
\end{array}$ & $\begin{array}{c}-0.7264^{* *} \\
(0.3185) \\
\end{array}$ & $\begin{array}{c}4.9059^{* * *} \\
(0.5816) \\
\end{array}$ & $\begin{array}{l}0.4746^{*} \\
(0.2880) \\
\end{array}$ & $\begin{array}{l}-0.3851 \\
(0.3415) \\
\end{array}$ & $\begin{array}{c}4.4822^{* * *} \\
(0.5956) \\
\end{array}$ \\
\hline Municipality FE & No & No & Yes & No & No & Yes \\
\hline Observations & 11209 & 11209 & 11209 & 11209 & 11209 & 11209 \\
\hline R-squared & 0.08 & 0.27 & 0.72 & 0.08 & 0.27 & 0.72 \\
\hline Mean & 79.91 & 79.91 & 79.91 & 79.91 & 79.91 & 79.91 \\
\hline
\end{tabular}

Standard errors clustered at the municipality level in parentheses: ${ }^{*} p<0.10,{ }^{* *} p<0.05,{ }^{* * *} p<0.01$ 
Table 37: Effect of Globo on the share of blank and null votes

Dependent variable: share of blank and null votes in $t, t=1972,1976,1982$

\begin{tabular}{|c|c|c|c|c|c|c|}
\hline & (1) & $\overline{(2)}$ & $\overline{(3)}$ & (4) & $(5)$ & $(6)$ \\
\hline Globo & $\begin{array}{c}0.8932^{* * *} \\
(0.1682)\end{array}$ & $\begin{array}{c}0.7609^{* * *} \\
(0.1874)\end{array}$ & $\begin{array}{l}-0.1048 \\
(0.3239)\end{array}$ & & & \\
\hline Globo $*$ year $==1972$ & & & & $\begin{array}{c}2.2656^{* * *} \\
(0.6247)\end{array}$ & $\begin{array}{c}2.1779^{* * *} \\
(0.6335)\end{array}$ & $\begin{array}{l}-0.2052 \\
(0.8041)\end{array}$ \\
\hline Globo $*$ year $==1976$ & & & & $\begin{array}{c}0.9653^{* * *} \\
(0.2590)\end{array}$ & $\begin{array}{c}1.1265^{* * *} \\
(0.2628)\end{array}$ & $\begin{array}{l}-0.0504 \\
(0.3922)\end{array}$ \\
\hline Globo $*$ year $==1982$ & & & & $\begin{array}{c}0.3782^{* *} \\
(0.1637)\end{array}$ & $\begin{array}{c}-0.1450 \\
(0.1977)\end{array}$ & $\begin{array}{l}-0.1323 \\
(0.4088)\end{array}$ \\
\hline $\log$ (population) & & $\begin{array}{c}-0.3024^{* * *} \\
(0.1007)\end{array}$ & $\begin{array}{c}2.2367^{* * *} \\
(0.5525)\end{array}$ & & $\begin{array}{c}-0.3308^{* * *} \\
(0.1007)\end{array}$ & $\begin{array}{c}2.2264^{* * *} \\
(0.5538)\end{array}$ \\
\hline Share of pop living in urban areas & & $\begin{array}{c}0.0031 \\
(0.0058)\end{array}$ & $\begin{array}{c}0.0210 \\
(0.0175)\end{array}$ & & $\begin{array}{l}-0.0003 \\
(0.0058)\end{array}$ & $\begin{array}{c}0.0211 \\
(0.0175)\end{array}$ \\
\hline Income per capita (in min wages) & & $\begin{array}{c}-1.3878^{* * *} \\
(0.3513)\end{array}$ & $\begin{array}{c}-2.0102^{* * *} \\
(0.5920)\end{array}$ & & $\begin{array}{c}-1.3042^{* * *} \\
(0.3511)\end{array}$ & $\begin{array}{c}-2.0111^{* * *} \\
(0.5933)\end{array}$ \\
\hline Average years of schooling & & $\begin{array}{c}0.9025^{* * *} \\
(0.2680)\end{array}$ & $\begin{array}{c}0.8541 \\
(0.6209)\end{array}$ & & $\begin{array}{c}0.9407^{* * *} \\
(0.2674)\end{array}$ & $\begin{array}{c}0.8511 \\
(0.6209)\end{array}$ \\
\hline Life expectancy & & $\begin{array}{c}-0.2735^{* * *} \\
(0.0430)\end{array}$ & $\begin{array}{c}-0.2930^{* *} \\
(0.1336)\end{array}$ & & $\begin{array}{c}-0.2774^{* * *} \\
(0.0430)\end{array}$ & $\begin{array}{c}-0.2908^{* *} \\
(0.1349)\end{array}$ \\
\hline Infant mortality (per 1000) & & $\begin{array}{c}-0.0328^{* * *} \\
(0.0041)\end{array}$ & $\begin{array}{c}-0.0442^{* *} \\
(0.0180)\end{array}$ & & $\begin{array}{c}-0.0337^{* * *} \\
(0.0041)\end{array}$ & $\begin{array}{c}-0.0438^{* *} \\
(0.0182)\end{array}$ \\
\hline Share of illiterate over 15 y.o. & & $\begin{array}{c}0.0621^{* * *} \\
(0.0123)\end{array}$ & $\begin{array}{c}0.0532^{*} \\
(0.0296)\end{array}$ & & $\begin{array}{c}0.0652^{* * *} \\
(0.0123)\end{array}$ & $\begin{array}{c}0.0532^{*} \\
(0.0296)\end{array}$ \\
\hline Share of employed people & & $\begin{array}{l}-0.0248 \\
(0.0181)\end{array}$ & $\begin{array}{l}-0.0335 \\
(0.0332)\end{array}$ & & $\begin{array}{c}-0.0251 \\
(0.0180)\end{array}$ & $\begin{array}{c}-0.0333 \\
(0.0332)\end{array}$ \\
\hline Gini & & $\begin{array}{c}1.1363 \\
(1.3243)\end{array}$ & $\begin{array}{l}-0.4997 \\
(2.2002)\end{array}$ & & $\begin{array}{c}1.2176 \\
(1.3241)\end{array}$ & $\begin{array}{l}-0.5011 \\
(2.1951)\end{array}$ \\
\hline Wealth index & & $\begin{array}{c}0.4382^{* * *} \\
(0.1680)\end{array}$ & $\begin{array}{c}1.0406^{* * *} \\
(0.3754)\end{array}$ & & $\begin{array}{c}0.4397^{* * *} \\
(0.1680)\end{array}$ & $\begin{array}{c}1.0406^{* * *} \\
(0.3770)\end{array}$ \\
\hline Share of households with TV & & $\begin{array}{c}0.0306^{* * *} \\
(0.0080)\end{array}$ & $\begin{array}{c}0.0095 \\
(0.0144)\end{array}$ & & $\begin{array}{c}0.0364^{* * *} \\
(0.0081)\end{array}$ & $\begin{array}{c}0.0098 \\
(0.0149)\end{array}$ \\
\hline year $==1976$ & $\begin{array}{c}-4.3490^{* * *} \\
(0.2052)\end{array}$ & $\begin{array}{c}-4.3267^{* * *} \\
(0.2059)\end{array}$ & $\begin{array}{c}-4.2058^{* * *} \\
(0.2624)\end{array}$ & $\begin{array}{c}-4.2532^{* * *} \\
(0.2222)\end{array}$ & $\begin{array}{c}-4.3008^{* * *} \\
(0.2227)\end{array}$ & $\begin{array}{c}-4.2278^{* * *} \\
(0.2851)\end{array}$ \\
\hline year $==1982$ & $\begin{array}{c}-2.3352^{* * *} \\
(0.2100)\end{array}$ & $\begin{array}{c}-2.1404^{* * *} \\
(0.2576)\end{array}$ & $\begin{array}{c}-1.4751^{* *} \\
(0.5734)\end{array}$ & $\begin{array}{c}-1.8821^{* * *} \\
(0.2264)\end{array}$ & $\begin{array}{c}-1.5837^{* * *} \\
(0.2643)\end{array}$ & $\begin{array}{c}-1.4715^{* *} \\
(0.5819)\end{array}$ \\
\hline Municipality FE & No & No & Yes & No & No & Yes \\
\hline Observations & 11200 & 11200 & 11200 & 11200 & 11200 & 11200 \\
\hline R-squared & 0.05 & 0.06 & 0.43 & 0.05 & 0.06 & 0.43 \\
\hline Mean & 8.45 & 8.45 & 8.45 & 8.45 & 8.45 & 8.45 \\
\hline
\end{tabular}

Standard errors clustered at the municipality level in parentheses: ${ }^{*} p<0.10,{ }^{* *} p<0.05,{ }^{* * *} p<0.01$ 


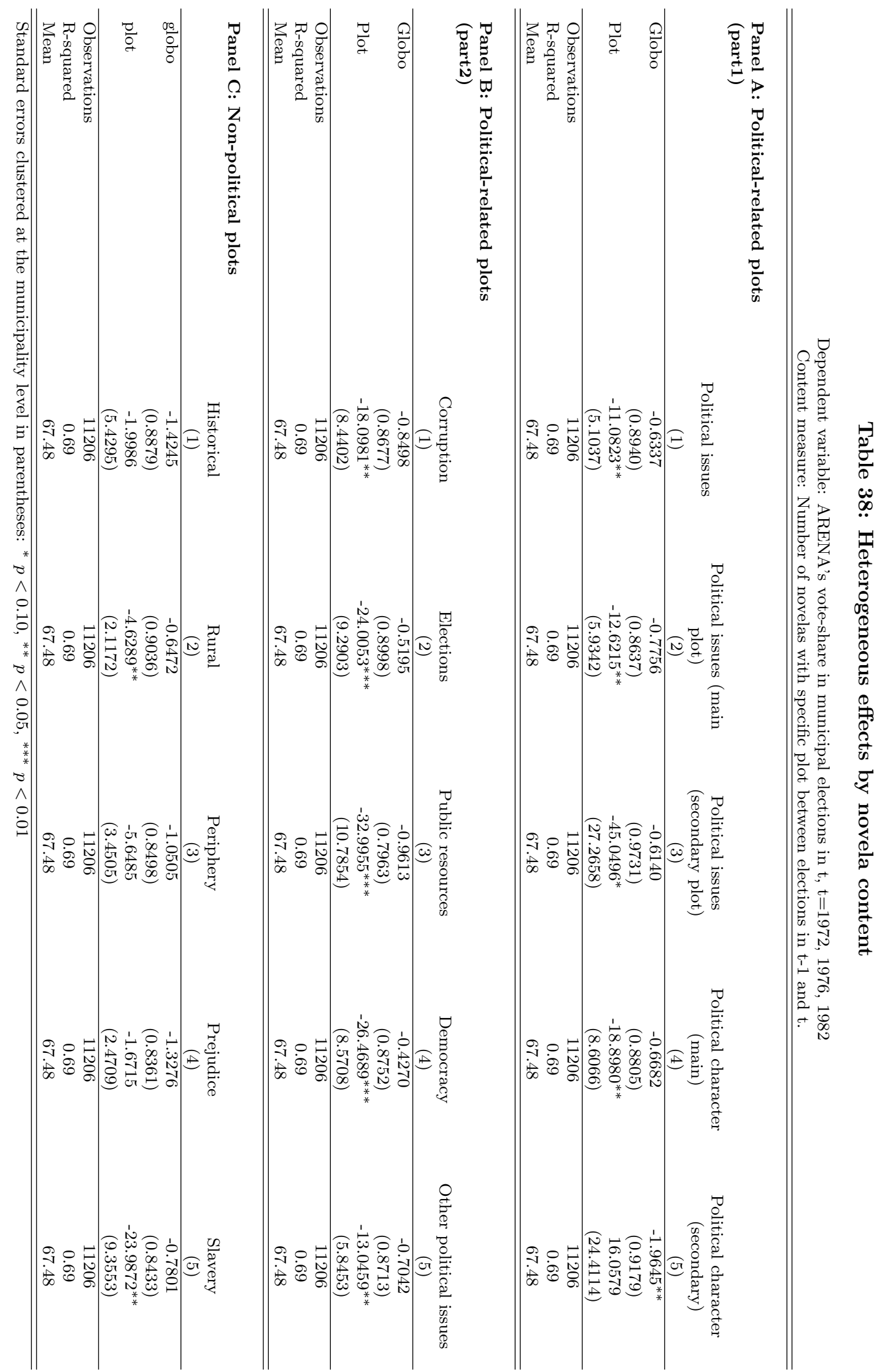




\section{Appendix $\mathrm{C}$}

Table 39: Distribution of TSE Districts across Municipalities

\begin{tabular}{ccc}
\hline \hline $\begin{array}{c}\text { Number of Districts within } \\
\text { the Municipality }\end{array}$ & $\begin{array}{c}\text { Number of } \\
\text { Municipalities }\end{array}$ & $\begin{array}{c}\text { Frequence } \\
(\%)\end{array}$ \\
\hline 1 & 600 & 93.02 \\
2 & 31 & 4.81 \\
3 & 3 & 0.47 \\
4 & 3 & 0.47 \\
6 & 3 & 0.47 \\
7 & 3 & 0.47 \\
10 & 1 & 0.16 \\
58 & 1 & 0.16 \\
\hline Total & 645 & 100.00 \\
\hline \hline
\end{tabular}

Table 40: Distribution of Municipalities across TSE Districts

\begin{tabular}{ccc}
\hline \hline $\begin{array}{c}\text { Number of Municipalities within } \\
\text { the TSE District }\end{array}$ & $\begin{array}{c}\text { Number of } \\
\text { Districts }\end{array}$ & $\begin{array}{c}\text { Frequence } \\
(\%)\end{array}$ \\
\hline 1 & 243 & 57.45 \\
2 & 83 & 19.62 \\
3 & 53 & 12.53 \\
4 & 20 & 4.73 \\
5 & 9 & 2.13 \\
6 & 11 & 2.60 \\
7 & 3 & 0.71 \\
10 & 1 & 0.24 \\
\hline Total & 423 & 100.00 \\
\hline \hline
\end{tabular}




\begin{tabular}{|c|c|c|c|c|c|}
\hline \multirow{3}{*}{ Variable } & \multicolumn{5}{|c|}{ Mean [Std. Deviation] } \\
\hline & $\mathrm{PT}$ & PSDB & PTB & PMDB & Pooling \\
\hline & Sample & Sample & Sample & Sample & Sample \\
\hline \multicolumn{6}{|c|}{ Panel A: Elections for City Councilor } \\
\hline \multirow[t]{2}{*}{ teachers_party ${ }_{d}$} & 1.9347 & 0.9697 & 0.6715 & 0.5815 & 1.0378 \\
\hline & {$[1.5074]$} & {$[1.2972]$} & {$[0.9585]$} & {$[0.9784]$} & {$[1.3205]$} \\
\hline \multirow[t]{2}{*}{ target_group $_{s, d}$} & 1.3959 & 1.4078 & 1.3988 & 1.4049 & 1.4019 \\
\hline & {$[3.8973]$} & {$[3.9128]$} & {$[3.896]$} & {$[3.913]$} & {$[3.9048]$} \\
\hline \multirow[t]{2}{*}{ placebo_group $_{s, d}$} & 0.0582 & 0.0583 & 0.0581 & 0.0581 & 0.0582 \\
\hline & {$[0.2660]$} & {$[0.2654]$} & {$[0.2655]$} & {$[0.2652]$} & {$[0.2655]$} \\
\hline \multirow[t]{2}{*}{ 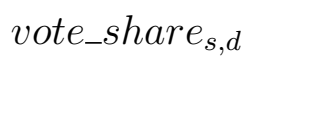 } & 12.7132 & 14.4371 & 6.3203 & 6.8052 & 10.0725 \\
\hline & {$[9.436]$} & {$[8.5969]$} & {$[5.7611]$} & {$[6.9614]$} & {$[8.5935]$} \\
\hline \multicolumn{6}{|c|}{ Panel B: Elections for Mayor } \\
\hline \multirow[t]{2}{*}{ teachers_party $y_{d}$} & 2.0944 & 0.9133 & 0.6290 & 0.7462 & 1.3052 \\
\hline & {$[1.3282]$} & {$[1.2308]$} & {$[1.2728]$} & {$[1.4334]$} & {$[1.4318]$} \\
\hline \multirow{2}{*}{ target_group $_{s, d}$} & 1.2376 & 1.3446 & 1.7143 & 1.5614 & 1.3589 \\
\hline & {$[3.6374]$} & {$[3.8119]$} & [4.4341] & {$[4.1125]$} & {$[3.8387]$} \\
\hline \multirow[t]{2}{*}{ placebo_group $_{s, d}$} & 0.0532 & 0.0573 & 0.0685 & 0.0620 & 0.0572 \\
\hline & {$[0.2525]$} & {$[0.2646]$} & {$[0.3003]$} & {$[0.2766]$} & {$[0.2645]$} \\
\hline \multirow[t]{2}{*}{ 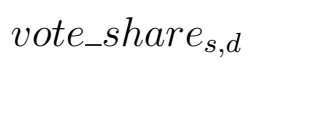 } & 29.6034 & 27.5988 & 29.3473 & 32.1056 & 29.0338 \\
\hline & {$[18.0486]$} & {$[17.6398]$} & {$[19.0228]$} & {$[20.5789]$} & [18.3488] \\
\hline \multicolumn{6}{|c|}{ Panel C: Elections for State Deputy } \\
\hline \multirow[t]{2}{*}{ teachers_party } & 2.0240 & 0.9424 & 0.6526 & 0.5759 & 1.0487 \\
\hline & [1.6447] & [1.2298] & {$[0.9165]$} & [1.0000] & [1.3602] \\
\hline \multirow{2}{*}{ target_group $_{s, d}$} & 1.2422 & 1.2422 & 1.2422 & 1.2422 & 1.2422 \\
\hline & {$[3.4257]$} & {$[3.4257]$} & {$[3.4257]$} & {$[3.4257]$} & {$[3.4257]$} \\
\hline \multirow[t]{2}{*}{ placebo_group $_{s, d}$} & 0.0751 & 0.0751 & 0.0751 & 0.0751 & 0.0751 \\
\hline & {$[0.4808]$} & {$[0.4808]$} & {$[0.4808]$} & {$[0.4808]$} & {$[0.4808]$} \\
\hline \multirow{2}{*}{ 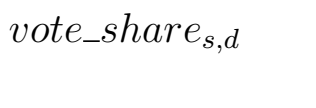 } & 19.2301 & 20.5681 & 3.7573 & 4.5577 & 12.0283 \\
\hline & [11.6853] & {$[11.5810]$} & {$[5.9013]$} & {$[6.5370]$} & {$[12.2192]$} \\
\hline
\end{tabular}


Table 42: Summary Statistics by Estimating Sample - 2/3

\begin{tabular}{|c|c|c|c|c|c|}
\hline \multirow{3}{*}{ Variable } & \multicolumn{5}{|c|}{ Mean [Std. Deviation] } \\
\hline & $\mathrm{PT}$ & PSDB & PTB & PMDB & Pooling \\
\hline & Sample & Sample & Sample & Sample & Sample \\
\hline \multicolumn{6}{|c|}{ Panel D: Elections for Federal Deputy } \\
\hline teachers_party & $\begin{array}{c}2.0240 \\
{[1.6447]}\end{array}$ & $\begin{array}{c}0.9424 \\
{[1.2298]}\end{array}$ & $\begin{array}{c}0.6526 \\
{[0.9165]}\end{array}$ & $\begin{array}{c}0.5759 \\
{[1.0000]}\end{array}$ & $\begin{array}{c}1.0487 \\
{[1.3602]}\end{array}$ \\
\hline target_group $_{s, d}$ & $\begin{array}{c}1.2422 \\
{[3.4257]}\end{array}$ & $\begin{array}{c}1.2422 \\
{[3.4257]}\end{array}$ & $\begin{array}{c}1.2422 \\
{[3.4257]}\end{array}$ & $\begin{array}{c}1.2422 \\
{[3.4257]}\end{array}$ & $\begin{array}{c}1.2422 \\
{[3.4257]}\end{array}$ \\
\hline placebo_group $_{s, d}$ & $\begin{array}{c}0.0751 \\
{[0.4808]}\end{array}$ & $\begin{array}{c}0.0751 \\
{[0.4808]}\end{array}$ & $\begin{array}{c}0.0751 \\
{[0.4808]}\end{array}$ & $\begin{array}{c}0.0751 \\
{[0.4808]}\end{array}$ & $\begin{array}{c}0.0751 \\
{[0.4808]}\end{array}$ \\
\hline vote_share $_{s, d}$ & $\begin{array}{l}16.3167 \\
{[9.7816]}\end{array}$ & $\begin{array}{c}16.2179 \\
{[10.1069]}\end{array}$ & $\begin{array}{c}2.7722 \\
{[3.7867]}\end{array}$ & $\begin{array}{c}2.0545 \\
{[4.6703]}\end{array}$ & $\begin{array}{c}9.3403 \\
{[10.3220]}\end{array}$ \\
\hline \multicolumn{6}{|c|}{ Panel E: Elections for Governor } \\
\hline teachers_party & $\begin{array}{c}2.0240 \\
{[1.6447]}\end{array}$ & $\begin{array}{c}0.9424 \\
{[1.2298]}\end{array}$ & - & - & $\begin{array}{c}1.4832 \\
{[1.5496]}\end{array}$ \\
\hline target_group $_{s, d}$ & $\begin{array}{c}1.2422 \\
{[3.4257]}\end{array}$ & $\begin{array}{c}1.2422 \\
{[3.4257]}\end{array}$ & - & - & $\begin{array}{c}1.2422 \\
{[3.4257]}\end{array}$ \\
\hline placebo_group $_{s, d}$ & $\begin{array}{c}0.0751 \\
{[0.4808]}\end{array}$ & $\begin{array}{c}0.0751 \\
{[0.4808]}\end{array}$ & - & - & $\begin{array}{c}0.0751 \\
{[0.4808]}\end{array}$ \\
\hline vote_share $_{s, d}$ & $\begin{array}{c}31.5339 \\
{[11.1309]}\end{array}$ & $\begin{array}{c}45.939 \\
{[12.2659]}\end{array}$ & - & - & $\begin{array}{c}38.7365 \\
{[13.7496]}\end{array}$ \\
\hline \multicolumn{6}{|c|}{ Panel F: Elections for President } \\
\hline teachers_party & $\begin{array}{c}2.0240 \\
{[1.6447]}\end{array}$ & $\begin{array}{c}0.9424 \\
{[1.2298]}\end{array}$ & - & - & $\begin{array}{c}1.4832 \\
{[1.5496]}\end{array}$ \\
\hline target_group $_{s, d}$ & $\begin{array}{c}1.2422 \\
{[3.4257]}\end{array}$ & $\begin{array}{c}1.2422 \\
{[3.4257]}\end{array}$ & - & - & $\begin{array}{c}1.2422 \\
{[3.4257]}\end{array}$ \\
\hline placebo_group $_{s, d}$ & $\begin{array}{c}0.0751 \\
{[0.4808]}\end{array}$ & $\begin{array}{c}0.0751 \\
{[0.4808]}\end{array}$ & - & - & $\begin{array}{c}0.0751 \\
{[0.4808]}\end{array}$ \\
\hline vote_share $_{s, d}$ & $\begin{array}{c}34.5432 \\
{[12.3332]}\end{array}$ & $\begin{array}{c}37.9579 \\
{[12.5190]}\end{array}$ & - & - & $\begin{array}{c}36.2506 \\
{[12.5431]}\end{array}$ \\
\hline
\end{tabular}


Table 43: Summary Statistics by Estimating Sample - 3/3

\begin{tabular}{|c|c|c|c|c|c|}
\hline \multirow[b]{2}{*}{ Variable } & \multicolumn{5}{|c|}{ Mean [Std. Deviation] } \\
\hline & $\begin{array}{c}\text { PT } \\
\text { Sample }\end{array}$ & $\begin{array}{c}\text { PSDB } \\
\text { Sample }\end{array}$ & $\begin{array}{c}\text { PTB } \\
\text { Sample }\end{array}$ & $\begin{array}{l}\text { PMDB } \\
\text { Sample }\end{array}$ & $\begin{array}{l}\text { Pooling } \\
\text { Sample }\end{array}$ \\
\hline \multicolumn{6}{|c|}{ Panel G: Elections for Senator } \\
\hline teachers_party ${ }_{d}$ & $\begin{array}{c}2.0240 \\
{[1.6447]}\end{array}$ & $\begin{array}{c}0.9424 \\
{[1.2298]}\end{array}$ & $\begin{array}{c}0.6526 \\
{[0.9165]}\end{array}$ & - & $\begin{array}{c}1.2063 \\
{[1.4262]}\end{array}$ \\
\hline target_group $_{s, d}$ & $\begin{array}{c}1.2422 \\
{[3.4257]}\end{array}$ & $\begin{array}{c}1.2422 \\
{[3.4257]}\end{array}$ & $\begin{array}{c}1.2422 \\
{[3.4257]}\end{array}$ & - & $\begin{array}{c}1.2422 \\
{[3.4257]}\end{array}$ \\
\hline placebo_group $_{s, d}$ & $\begin{array}{c}0.0751 \\
{[0.4808]}\end{array}$ & $\begin{array}{c}0.0751 \\
{[0.4808]}\end{array}$ & $\begin{array}{c}0.0751 \\
{[0.4808]}\end{array}$ & - & $\begin{array}{c}0.0751 \\
{[0.4808]}\end{array}$ \\
\hline vote_share $e_{s, d}$ & $\begin{array}{l}16.4460 \\
{[6.5094]}\end{array}$ & $\begin{array}{l}22.2648 \\
{[6.3309]}\end{array}$ & $\begin{array}{c}7.9145 \\
{[2.7782]}\end{array}$ & - & $\begin{array}{l}15.5418 \\
{[8.0491]}\end{array}$ \\
\hline \multicolumn{6}{|c|}{ Panel H: 2008 Local Elections } \\
\hline teachers_party & $\begin{array}{c}1.9211 \\
{[1.5334]}\end{array}$ & $\begin{array}{c}0.9691 \\
{[1.2978]}\end{array}$ & $\begin{array}{c}0.6683 \\
{[0.9609]}\end{array}$ & $\begin{array}{c}0.5785 \\
{[0.9768]}\end{array}$ & $\begin{array}{c}1.0342 \\
{[1.3271]}\end{array}$ \\
\hline target_group $_{s, d}$ & $\begin{array}{c}1.4097 \\
{[3.9190]}\end{array}$ & $\begin{array}{c}1.4097 \\
{[3.9190]}\end{array}$ & $\begin{array}{c}1.4097 \\
{[3.9190]}\end{array}$ & $\begin{array}{c}1.4097 \\
{[3.9190]}\end{array}$ & $\begin{array}{c}1.4097 \\
{[3.9190]}\end{array}$ \\
\hline turnout $_{s, d}$ & $\begin{array}{l}85.2729 \\
{[4.5062]}\end{array}$ & $\begin{array}{l}85.2729 \\
{[4.5062]}\end{array}$ & $\begin{array}{l}85.2729 \\
{[4.5062]}\end{array}$ & $\begin{array}{l}85.2729 \\
{[4.5062]}\end{array}$ & $\begin{array}{l}85.2729 \\
{[4.5062]}\end{array}$ \\
\hline \multicolumn{6}{|c|}{ Panel I: 2010 General Elections } \\
\hline teachers_party & $\begin{array}{c}2.0240 \\
{[1.6447]}\end{array}$ & $\begin{array}{c}0.9424 \\
{[1.2298]}\end{array}$ & $\begin{array}{c}0.6526 \\
{[0.9165]}\end{array}$ & $\begin{array}{c}0.5759 \\
{[1.0000]}\end{array}$ & $\begin{array}{c}1.0487 \\
{[1.3602]}\end{array}$ \\
\hline target_group $_{s, d}$ & $\begin{array}{c}1.2422 \\
{[3.4257]}\end{array}$ & $\begin{array}{c}1.2422 \\
{[3.4257]}\end{array}$ & $\begin{array}{c}1.2422 \\
{[3.4257]}\end{array}$ & $\begin{array}{c}1.2422 \\
{[3.4257]}\end{array}$ & $\begin{array}{c}1.2422 \\
{[3.4257]}\end{array}$ \\
\hline turnout $_{s, d}$ & $\begin{array}{l}83.6163 \\
{[5.2672]}\end{array}$ & $\begin{array}{l}83.6163 \\
{[5.2672]}\end{array}$ & $\begin{array}{l}83.6163 \\
{[5.2672]}\end{array}$ & $\begin{array}{l}83.6163 \\
{[5.2672]}\end{array}$ & $\begin{array}{l}83.6163 \\
{[5.2672]}\end{array}$ \\
\hline
\end{tabular}


Figure 12: Municipalities in the State of São Paulo. Highlighted: City of São Paulo

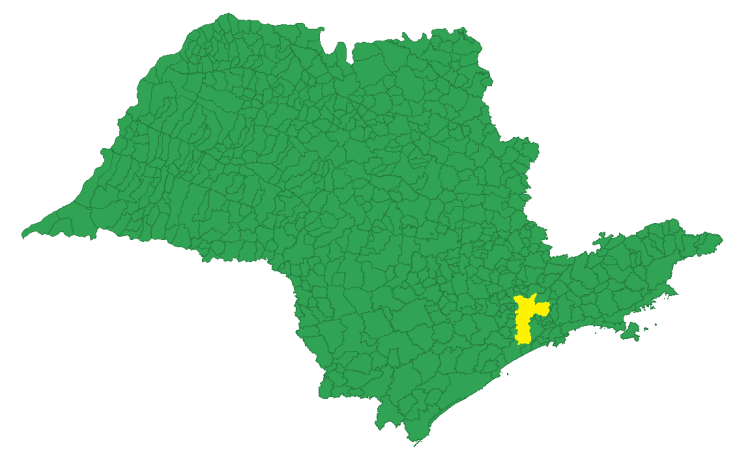

Figure 13: Polling Districts in the City of São Paulo

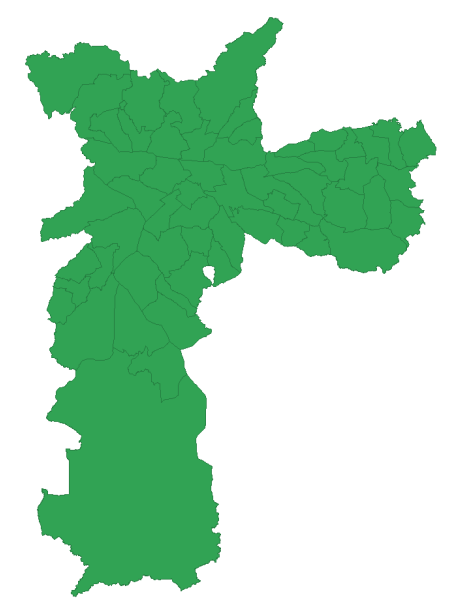


Figure 14: A Public School Employed as a Polling Place

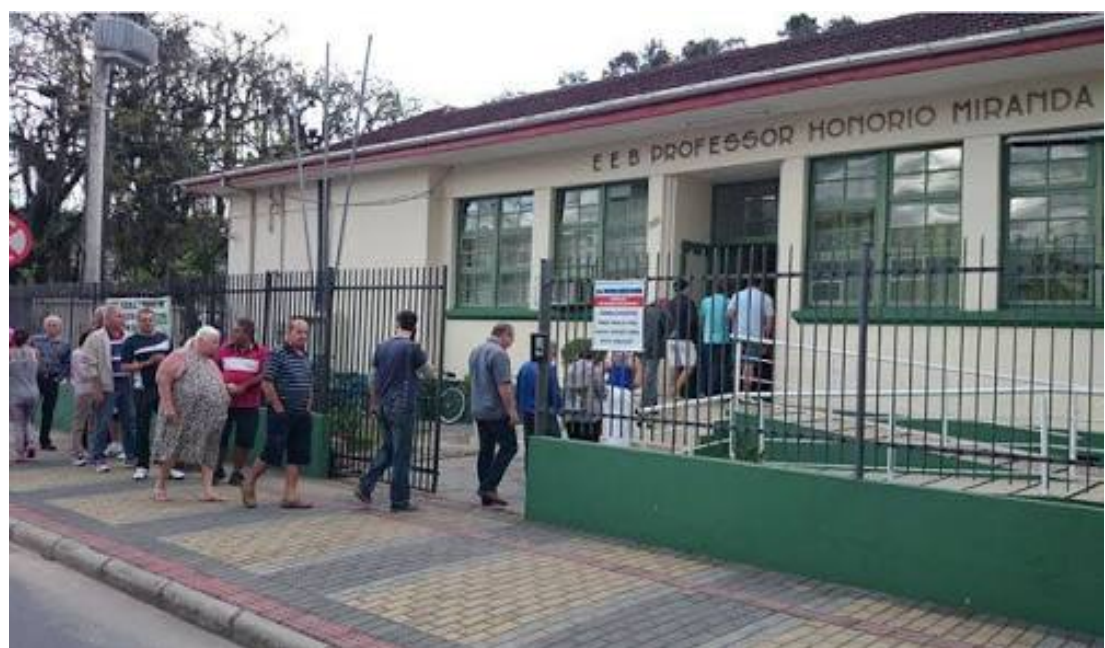

Source: http://www.cruzeirodovale.com.br/?eleicoes2014-confira-os-eleitos-no-estado-de-santacatarina\&ctd $=\mathbf{2 3 9 3 2}$.

Figure 15: A Public School Classroom Used as a Polling Station

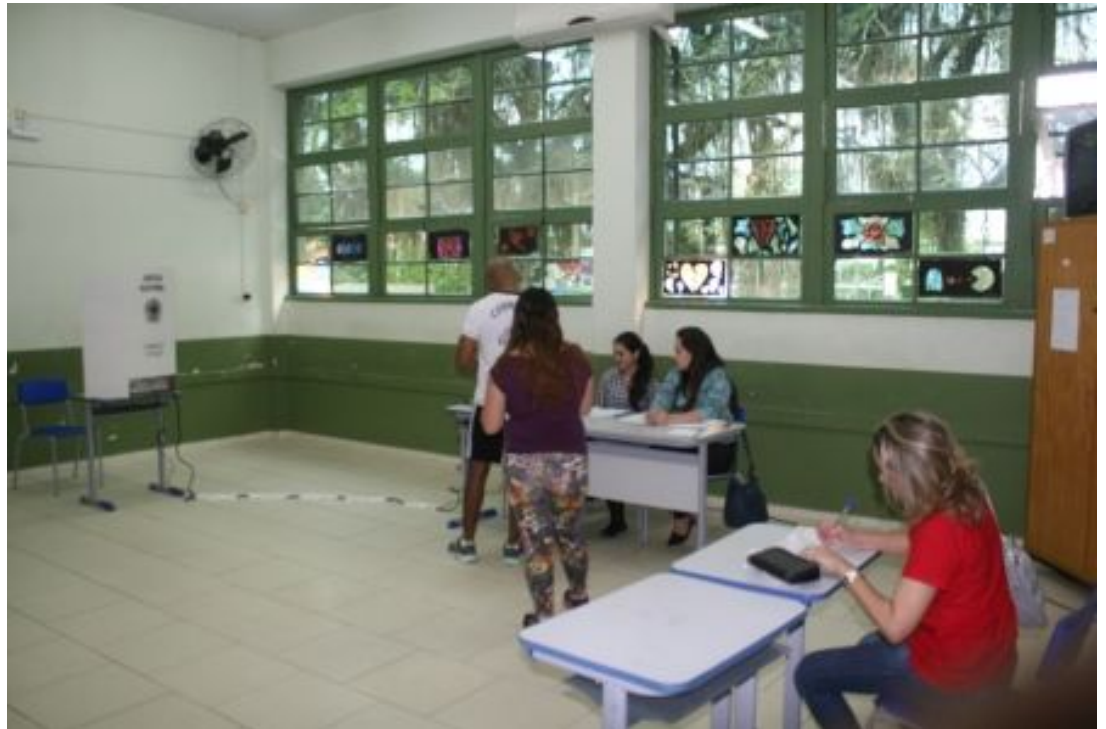

Source: http://www.cruzeirodovale.com.br/?eleicoes2014-confira-os-eleitos-no-estado-de-santacatarina\&ctd $=23932$. 